\title{
LAUDO ANTROPOLÓGICO SOBRE OS INDÍGENAS ACUSADOS DE TEREM COMETIDO DUPLO HOMICÍDIO E TENTATIVA DE HOMICÍDIO NO MUNICÍPIO DE DOURADOS, ESTADO DE MATO GROSSO DO SUL, BRASIL
}

GRACIELA CHAMORRO'

$U F G D, B R A S I L$

JORGE EREMITES DE OLIVEIRA ${ }^{2}$

UFPEL, BRASIL

\begin{abstract}
RESUMO: $O$ presente trabalho é a publicação na íntegra do relatório técnico-científico referente a uma perícia antropológica judicial concluida em junho de 2008 para Justiça Federal no município de Dourados, estado de Mato Grosso do Sul, Brasil. O estudo foi originalmente denominado Laudo antropológico sobre indígenas acusados de terem cometido duplo homicídio e tentativa de homicídio no Processo $N^{o}$. 2007.60.02.005511-5. Trata-se de uma perícia judicial a respeito de nove réus indígenas da comunidade de Passo Piraju, localizada na zona rural do referido municipio, constituída majoritariamente por pessoas das etnias Guarani e Kaiowa, acusados de terem cometido, em 2006, duplo homicídio e tentativa de homicídio de policiais civis. O processo tramitava em segredo de Justiça e por este motivo não pôde ser publicado anteriormente.
\end{abstract}

PALAVRAS-CHAVE: Etnologia Indígena, Laudos Antropológicos, Índios em Mato Grosso do Sul, Perícias Antropológicas, Povos Guarani e Kaiowa.

ASBTRACT: The present work is the complete publication of the technical-scientific report referring to an anthropological judicial investigation completed in June 2008 for Federal Justice in the municipality of Dourados, State of Mato Grosso do Sul, Brazil. The study was originally called Anthropological report on indigenous people accused of having committed double homicide and attempted murder in Case No. 2007.60.02.005511-5. This is a judicial investigation of nine indigenous defendants from the community of Passo Piraju, located in the rural area of the municipality, consisting mainly of people of the Guarani and Kaiowa ethnic groups, accused of having committed a double homicide in 2006 and attempted homicide of polices. The proceeding was processed in a court of secrecy and for this reason cannot be published previously.

KEYWORDS: Indigenous Ethnology, Anthropological Reports, Indians in Mato Grosso do Sul State, Anthropological Expertise, Peoples Guarani and Kaiowa.

\footnotetext{
${ }^{1}$ Professora da graduação em História e no Programa de Pós-Graduação em História (Universidade Federal da Grande Dourados, Brasil). E-mail: candidaarguello@ufgd.edu.br

${ }^{2}$ Professor do curso de Antropologia e do Programa de Pós-Graduação em Memória Social e Patrimônio Cultural (Universidade Federal de Pelotas, Brasil). E-mail: eremites.br@gmail.com 


\section{Histórico dos trabalhos e procedimentos científicos}

A presente perícia antropológica foi realizada em cumprimento ao Mandado de Intimação Criminal $\mathrm{n}^{\circ}$. 0020/2008-SE01/SECRI/EAS, da Justiça Federal, $1^{\text {a }}$ Vara Federal de Dourados, $2^{\text {a }}$ Subseção Judiciária de Mato Grosso do Sul, expedido em 03/03/2008, conforme consta nos Autos $\mathrm{n}^{\circ}$. 2007.60.02.005511-5. Neste processo são réus os indígenas Carlito de Oliveira (Kaiowa), Ezequiel Valensuela ("Enoque"; Kaiowa), Hermínio Romero ("Roberto Farinha"; Kaiowa), Jair Aquino Fernandes (Guarani), Lindomar Brites de Oliveira (Guarani), Marcio da Silva Lins (Ofaié), Paulino Lopes (Kaiowa), Sandra Arevalo Savala (Kaiowa) e Valmir Junior Savala (Kaiowa).

A primeira etapa dos trabalhos de campo foi realizada durante os dias $1^{\circ}$ e $02 / 05 / 2008$, ocasião em que os peritos e a assistente técnica do MPF (Ministério Público Federal), antropóloga Fernanda Paranhos, estiveram com cinco dos nove réus na comunidade indígena de Passo Piraju, localizada na região de Porto Cambira, zona rural do município de Dourados $^{3}$. São eles: Carlito de Oliveira, Ezequiel Valensuela, Jair Aquino Fernandes, Lindomar Brites de Oliveira e Valmir Junior Savala. Quatro réus não foram ali encontrados na ocasião: Hermínio Romero, Marcio da Silva Lins, Paulino Lopes e Sandra Arevalo Savala; o primeiro é tido por esta comunidade como misteriosamente desaparecido ou morto após sua soltura do Presídio de Jateí. Até então nenhum dos réus tinha sido informado pelo órgão indigenista oficial sobre a data de início da perícia, tampouco a FUNAI (Fundação Nacional do Índio) enviou seu assistente técnico até o local.

Posteriormente, nos dias 02, 03 e 05/06/2008, em atendimento ao Mandado de Intimação Criminal $n^{\circ}$. 0086/2008-SE01/SECRI/EAS, expedido em 16/05/2008, os peritos retornaram àquela comunidade para a conclusão dos trabalhos de campo. Na oportunidade puderam estar com os réus ausentes na primeira etapa dos trabalhos periciais exceto Hermínio Romero. Porém não contaram com a participação de quaisquer assistentes técnicos.

A respeito dos procedimentos científicos adotados para a realização dos estudos periciais, foi feito uso concatenado de metodologias mundialmente consagradas no campo da antropologia cultural ou social ${ }^{4}$. Os métodos recorridos foram o etnográfico, 0 genealógico e o da história de vida. Trata-se de metodologias bastante seguras e recorridas com sucesso em outras perícias realizadas para a

\footnotetext{
${ }^{3} \mathrm{Em}$ antropologia o termo comunidade é utilizado para se referir a um grupo de indivíduos que vivem em um mesmo local e que está política e socialmente organizado por meio de uma rede de relações sociais estabelecidas segundo uma lógica cultural particular. Uma comunidade possui uma escala de amplitude menor que a de uma sociedade e ambas podem coexistir simultaneamente. No caso de Passo Piraju, tratase de uma comunidade indígena composta predominantemente por indivíduos das etnias Kaiowa e Guarani. Ao longo deste laudo também é utilizado o termo aldeia no sentido de a área onde está assentada ou acomodada esta comunidade.

${ }^{4}$ A antropologia cultural ou social é aqui entendida como o campo da antropologia dedicado ao estudo das
sociedades humanas no tempo e no espaço a partir de sua dimensão sociocultural, de acordo com a tradição
antropológica de grande parte dos países americanos.
} 
Justiça Federal em Mato Grosso do Sul, nas quais o perito da equipe participou (EREMITES DE OLIVEIRA e PEREIRA, 2003, 2007).

O método etnográfico, também conhecido como observação participante, consiste na observação direta da vida social e da cultura de grupos humanos. Foi utilizado na observação dos réus e da comunidade indígena de Passo Piraju. Este procedimento científico foi desenvolvido a partir da segunda metade do século XIX, concomitantemente na Europa e na América. Sua efetiva consolidação na prática antropológica se deu com a divulgação do clássico Argonautas do Pacífico ocidental: um relato do empreendimento e da aventura dos nativos nos arquipélagos da Nova Guiné Melanésia, escrito pelo antropólogo polonês Bronislaw Malinowski (1884-1942) e publicado pela primeira vez em 1922 (MALINOWSKI, 1984).

$\mathrm{Na}$ opinião do antropólogo brasileiro Roberto Cardoso de Oliveira (2000) - um dos primeiros antropólogos profissionais do país, exprofessor da Universidade de Brasília (UnB), falecido em 2006 e autor do livro $\mathbf{O}$ trabalho do antropólogo -, a pesquisa etnográfica consiste em três procedimentos básicos: "olhar", "ouvir" e "escrever". O olhar e o ouvir fazem parte da primeira etapa dos trabalhos antropológicos, aquela que é realizada em campo, isto é, o registro etnográfico de dados empiricamente observáveis. O escrever constitui a segunda etapa das pesquisas, a interpretação etnológica, quer dizer, a análise teórica dos dados etnográficos obtidos durante a observação do grupo estudado. De acordo com o referido pesquisador:

\begin{abstract}
Examinados o olhar, o ouvir e o escrever, a que conclusões podemos chegar? Como procurei mostrar neste início, essas "faculdades" do espírito têm características bem precisas quando exercitadas na órbita das ciências sociais e, de um modo todo especial, na da antropologia. Se o olhar e o ouvir constituem a nossa percepção da realidade focalizada na pesquisa empírica, o escrever passa a ser parte quase indissociável do nosso pensamento, uma vez que o ato de escrever é simultâneo ao ato de pensar. Quero chamar a atenção sobre isso, de modo a tornar claro que - pelo menos no meu modo de ver - é no processo de redação de um texto que nosso pensamento caminha, encontrando soluções que dificilmente aparecerão antes da textualização dos dados provenientes da observação sistemática (CARDOSO DE OLIVEIRA, 2000, p.31-32).
\end{abstract}

A proposição apresentada pelo renomado cientista social vai ao encontro dos ensinamentos do antropólogo francês Marcel Mauss (1967, 1993), um dos fundadores da antropologia moderna, sobrinho e discípulo de Émile Durkheim (1858-1917), quem, por sua vez, é considerado o fundador da sociologia moderna. Ele assim registrou no Manual de etnografia, escrito originalmente na primeira metade do século XX e publicado pela primeira vez em 1967: 
A ciência etnológica [antropologia] tem como fim a observação das sociedades, como objeto o conhecimento dos fatos sociais. Registra estes fatos e, quando necessário, estabelece a respectiva estatística; e publica documentos que oferecem o máximo de certeza. O etnógrafo deve ter a preocupação de ser exato, complexo; deve ter o sentido dos fatos e das relações entre eles, o sentido das proporções e das articulações (MAUSS, 1993, p.21-22).

Segundo a linha argumentativa de Mauss, a pesquisa etnográfica tem de ser exata, haja vista que a "intuição não tem lugar na ciência etnológica, ciência de verificações e estatísticas" (MAUSS, 1993, p.22). Suas ideias seguem a perspectiva inicial formulada pelo próprio Malinowski:

\begin{abstract}
Nas ciências históricas, como já foi dito, ninguém pode ser visto com seriedade se fizer mistério de suas fontes e falar do passado como se o conhecesse por adivinhação. Na etnografia, o autor é, ao mesmo tempo, o seu próprio cronista e historiador; suas fontes de informação são, indubitavelmente, bastante acessíveis, mas também extremamente enganosas e complexas; não estão incorporadas a documentos fixos, mas sim ao comportamento e memória de seres humanos. $\mathrm{Na}$ etnografia, é frequentemente imensa a distância entre a apresentação final dos resultados da pesquisa e o material bruto das informações coletadas pelo pesquisador através de suas próprias observações, das asserções dos nativos, do caleidoscópio da vida tribal (MALINOWSKI, 1984, P.18-19).
\end{abstract}

No contexto pericial é imperativo que a pesquisa etnográfica seja feita por experts que possuam reconhecida competência científica e amplo conhecimento sobre as etnias em questão, cujas investigações devem ser direcionadas para a busca de respostas seguras aos quesitos apresentados pelo Juízo e pelas partes.

Além disso, o método genealógico foi outro procedimento científico recorrido durante as pesquisas de campo. Trata-se igualmente de um recurso metodológico muitíssimo utilizado em estudos sobre grupos étnicos. Foi primeiramente desenvolvido na década de 1910 pelo antropólogo britânico William Halse Rivers (1864-1922) (CARDOSO DE OLIVEIRA, 1991).

Através da aplicação do método genealógico foi averiguada a participação dos réus na constituição dos grupos de parentesco existentes na comunidade de Passo Piraju. Esses grupos são definidos por relações de ancestralidade, consanguinidade, afinidade e aliança política. O método permitiu ainda aferir o grau de proximidade dos indígenas em termos da constituição de um grupo humano com vínculos biológicos, históricos e sociais com aquela região situada na bacia do rio 
Dourados. Também contribuiu para avaliar o nível de compreensão dos réus das regras existentes na sociedade nacional.

Nos estudos genealógicos são confeccionados diagramas de parentesco em que indivíduos são representados por alguns símbolos, conforme explicado no quadro a seguir.

Quadro 1: Símbolos usados nos diagramas de parentesco.

\begin{tabular}{|c|c|}
\hline SÍMBOLO & SIGNIFICADO \\
\hline & Homem \\
\hline & Mulher \\
\hline & Conjugalidade \\
\hline & Conjugalidade desfeita \\
\hline & Descendência ou filiação \\
\hline & Germanidade (filhos do mesmo pai e mesma mãe) \\
\hline & Ego ("eu" em latim; pessoa de referência na genealogia) \\
\hline & $\begin{array}{l}\text { Indicador de filhos independente da quantidade e do } \\
\text { sexo dos indivíduos }\end{array}$ \\
\hline
\end{tabular}

NOTA: Cada plano horizontal do diagrama, como no símbolo correspondente à germanidade, corresponde a uma geração de indivíduos.

Paralelamente foi aplicado o método da história de vida e, com ele, analisada a memória genealógica dos réus e de outros membros da comunidade indígena que colaboraram com os trabalhos periciais. Por meio de entrevistas individuais e coletivas, registradas em gravador digital e em diários de campo, foi levantada e analisada a história de vida dos réus e a memória genealógica de outros indivíduos de Passo Piraju. Dados como local de nascimento, filiação, formação, grupos de referência, tipos de vínculos do grupo, grau de compreensão e inserção junto às instituições da sociedade nacional, dentre outros, trouxeram importantes subsídios para o entendimento da situação pretérita e atual dos réus no contexto étnico local.

A história de vida é um método qualitativo tão antigo quanto o são os métodos etnográfico e genealógico. Entrementes, foi na antropologia praticada nas primeiras décadas do século $X X$ que este método teve um tratamento científico adequado e foi cientificamente sistematizado. Hoje em dia esta metodologia é bastante recorrida por historiadores, psicólogos, sociólogos e outros cientistas sociais, cada qual com suas peculiaridades e objetivos científicos (DEBERT, 1983; BECKER, 1993).

Os dados registrados sobre a história de vida de cada réu entrevistado foram controlados por meio de diagramas de parentesco, nos quais diversas informações foram sistematicamente cruzadas para dirimir, por exemplo, eventuais dúvidas e informações que pudessem denotar contradição. No estudo etnográfico de grupos indígenas este método é imprescindível por se tratar de grupos humanos de tradição oral e não de tradição escrita. Grupos assim, como é o caso dos Guarani 
e Kaiowa, possuem um idioma cultural próprio e distinto do predominante na sociedade nacional.

No trabalho de campo em antropologia, a aplicação desses três métodos científicos requer a construção de um ambiente de empatia e respeito entre entrevistadores ou analistas (antropólogos) e entrevistados ou interlocutores (indígenas). Dessa forma é comum, por exemplo, os peritos manifestarem concordância com o conteúdo da fala dos narradores. Assim o fazem para indicar que compreendem seus argumentos, o que os estimula a prosseguir em suas narrativas. Na antropologia moderna também é importante fazer uso do idioma nativo nesta comunicação - no caso o guarani -, pois para compreender os indígenas em sua perspectiva e racionalidade próprias é fundamental "ouvi-los" em sua própria língua. Entretanto, no ato de escrever os cientistas sociais têm a oportunidade de exercer a reflexão crítica sobre o conteúdo das narrativas e explorar suas significações, ambiguidades e contradições.

No caso deste laudo em particular, faz-se mister explicar que a perita da equipe é uma reconhecida especialista na língua guarani falada pelos indígenas, o que em muito favoreceu a interlocução mantida com os réus e com outros membros da comunidade de Passo Piraju. Manter os diálogos preferencialmente em língua guarani foi um procedimento bastante profícuo durante os trabalhos de campo, haja vista que favoreceu o estabelecimento de uma rápida relação de empatia entre os experts do Juízo e os acusados.

Acrescenta-se a tudo isso o conhecimento prévio da literatura etnológica e etno-histórica mais relevante sobre os grupos étnicos a que pertencem os réus, além de pesquisas feitas na Internet, a rede mundial de computadores, no Ministério Público Federal em Dourados, na Biblioteca Central e no Centro de Documentação Regional da Universidade Federal da Grande Dourados (UFGD) ${ }^{5}$.

No que se refere aos trabalhos de campo, foram ainda tomadas as devidas precauções no sentido de fazer o georreferenciamento de todos os locais apontados pelos indígenas como sendo pontos importantes para o conhecimento dos fatos. Isto foi feito com o auxílio de um aparelho GPS, marca Garmin, modelo Etrex, com 12 canais para a recepção de satélites, por meio do qual foram obtidas coordenadas UTM (Sistema Universal Transversa de Mercator). Trata-se de coordenadas expressas em metros, cujos eixos cartesianos de origem são a linha do Equador para coordenadas Norte $(\mathbf{N})$, e o meridiano central de cada zona para coordenadas Leste (E).

As questões técnico-científicas apresentadas até o momento justificam, pois, a adoção de procedimentos antropológicos como sendo de fundamental importância para a compreensão do idioma cultural de indígenas acusados de crimes em processos judiciais. Neste sentido, a

\footnotetext{
${ }^{5}$ A UFGD possui [à época da conclusão deste laudo] a maior e mais qualificada equipe de antropólogos do estado de Mato Grosso do Sul. A maior parte está vinculada ao NECSO (Núcleo de Estudos em Ciências Sociais) e ao ETNOLAB (Laboratório de Arqueologia, Etnologia e Etno-história), da Faculdade de Ciências Humanas, e atua em vários cursos de graduação e pós-graduação oferecidos pela instituição, sobremaneira nos de Ciências Sociais, Direito, História e Licenciatura Indígena.
} 
conduta ética e o rigor na aplicação de técnicas, métodos e teorias durante a realização dos trabalhos antropológicos asseguram a imparcialidade científica da perícia judicial. Isto porque o trabalho de peritagem resulta na produção de um laudo de caráter técnico-científico, solicitado e avaliado pelo judiciário para a tomada de decisões sobre direitos. Seu objetivo é "traduzir melhor a realidade que está sendo tematizada no caso examinado pelo juiz", conforme explicou o antropólogo Luís Roberto Cardoso de Oliveira, professor da UnB, especialista em antropologia do direito e da política e presidente da ABA (Associação Brasileira de Antropologia) durante a gestão 2006-2008 (CARDOSO DE OLIVEIRA, 2004, p.40).

Feitas essas considerações de natureza técnico-científica e teóricometodológica, cumpre explicar o uso de alguns termos recorrentes neste trabalho, uma vez que seu entendimento é relevante para a compreensão do laudo pericial.

O primeiro diz respeito à grafia de nomes tribais. Conforme estabelecido em convenção antropológica internacional, realizada em 1954 na cidade do Rio de Janeiro, o nome de etnias indígenas é grafado de forma fonética e no singular. Quando empregados em expressões como "os Guarani" e "os Kaiowa", são grafados como nome próprio. No entanto, quando usados como adjetivos permanecem no singular, porém como nomes comuns, a exemplo de "a reza guarani" e "as casas kaiowa" (vide ABA, 1954).

No que se refere à grafia das palavras em língua guarani, neste laudo elas estão grafadas em itálico e de acordo com a fonética das palavras, a saber: "ch" = "ch" e " $x$ " (como em português "chácara" e "xícara"), "h" = "h" aspirado (como em inglês "house" e "help"), "j" = "jd" (como em inglês "jump" e "jeep"), k = c (como em português "casa"), "ñ " = "nh" (como português "ninho" e "cozinha"), "y" (a sexta vogal) = "i" gutural (como em guarani che sy, que significa "minha mãe"; o som do " $y$ " não existe em português) etc. Utilizou-se ainda o apóstrofo para marcar um corte ou salto na pronúncia das palavras (como em guarani $k a$ 'a = mata, erva-mate). Ocorre também que grande parte das palavras em guarani é oxítona e não acompanha acento agudo, diferentemente do que ocorre em português com as palavras terminadas em "a", "e" e "o". Apenas as paroxítonas e as proparoxítonas são acentuadas (vide GUASCH, 2001).

O idioma guarani dos índios Kaiowa e Guarani é uma língua tribal, ao passo que o falado no Paraguai é uma língua de origem colonialista, isto é, que emergiu no contexto da conquista e colonização ibéricas da região platina. Disso derivam algumas diferenças semânticas. Exemplo: entre os grupos indígenas citados a palavra karai (pronuncia-se "caraí") é costumeiramente empregada para se referir ao indivíduo que não é indígena; no Paraguai o mesmo vocábulo é mais usado no sentido de "senhor", ou seja, é um tratamento respeitoso dispensado a autoridades, pessoas de maior idade etc. Significa dizer que alguém que domine o guarani falado no Paraguai não compreenderá automaticamente a totalidade do idioma homônimo falado pelos indígenas, tampouco estarão aptos à função de tradutor-intérprete para decodificar, por exemplo, a fala dos réus aos operadores do direito. 
No caso dos Guarani, cumpre fazer uma pequena digressão. Em Mato Grosso do Sul este povo indígena se autodenomina com o mesmo nome de sua língua nativa, a guarani, e também é chamado de Ñandeva. No Paraguai são mais conhecidos como "Ava-Guarani" ou simplesmente "Ava", e às vezes como "Chiripa". No caso dos Kaiowa, esta é a autodenominação de um povo indígena que também se reconhece como "Paĩ-Tavyterã", ou simplesmente "Paĩ", sobretudo naquele país vizinho. Portanto, Kaiowa e Paĩ-Tavyterã ou Paĩ correspondem a uma mesma etnia indígena, assim como Guarani, Ñandeva e Ava-Guarani e Chiripa correspondem a uma outra.

Por isso os peritos optaram por se referirem aos dois povos indígenas como, respectivamente, Guarani e Kaiowa, e não como "Guarani-Ñandeva" ou "Guarani-Kaiowa". Assim o fizeram em observância e respeito à maneira como eles se auto-identificam no Brasil e pelo fato de constituírem duas etnias distintas. Ademais, os Kaiowa não apreciam ser chamados de Guarani, tampouco os Guarani gostam de ser chamados de Kaiowa, embora ambos possuam muitos elementos socioculturais em comum.

A respeito do nome Ofaié, cabe explicar que esta é a autodenominação de um povo indígena também conhecido como "OfaiéXavante", embora não façam parte do povo Xavante que vive no estado de Mato Grosso. Por este motivo neste laudo eles são chamados apenas de Ofaié, o etnômio pelo qual se auto-identificam (NIMUENDAJU, 1993 [1920]; GUDSCHINSKY, 1974; SANTOS DUTRA, 1996, 2004).

Em suma, os trabalhos periciais foram concluídos por meio do uso de procedimentos científicos complementares, rigorosamente aplicados a partir do estabelecimento de uma relação de alteridade entre a antropologia e o mundo jurídico. Segundo Marcelo Veiga Beckhausen, procurador da $4^{a}$ Regional do Ministério Público Federal, uma relação deste nível é sobremaneira importante para a tomada de decisão em processos judiciais que envolvem direitos de indivíduos ou coletividades indígenas. Em sua opinião:

Estudos antropológicos poderão evidenciar várias questões. E não é somente em relação às terras que deverá ocorrer tais diálogos entre o Direito e a Antropologia. Nas disputas judiciais que envolvem os "elementos da cultura indígena", conforme afirma a jurisprudência, deverá, de forma obrigatória, ser utilizada a pesquisa antropológica para amparar qualquer decisão (BECKHAUSEN, 2008, p.4).

Desta forma, portanto, foi possível responder os quesitos formulados pelo Juízo e pelas partes, e discorrer sobre outros assuntos relevantes para a compreensão dos fatos e a tomada de decisão. 


\subsection{OS RÉUS, AO TEMPO DA AÇÃO, ERAM INTEIRAMENTE CAPAZES DE ENTENDER O CARÁTER ILÍCITO DE SUAS CONDUTAS?}

Não. A necessária explicação para esta negativa consta na resposta apresentada ao próximo quesito formulado pelo Juízo, o de $n^{0} .2 .2$, e aos demais quesitos respondidos ao longo deste laudo pericial.

\subsection{OS RÉUS ERAM, AO TEMPO DA AÇÃO, RELATIVAMENTE INCAPAZES DE ENTENDER O CARÁTER ILÍCITO DE SUAS CONDUTAS?}

Sim. Todos os réus "eram, ao tempo da ação, relativamente incapazes de entender o caráter ilícito" das condutas a que são acusados nos Autos, pois até então desconheciam - e ainda desconhecem - muitas das regras sociais e leis em vigor na sociedade nacional, haja vista que não participaram de sua elaboração, tampouco foram plenamente esclarecidos de sua existência, interpretação e aplicabilidade. Acrescenta-se a esta explicação o fato de a eles ainda não terem sido possibilitadas - inclusive por parte do órgão indigenista oficial - as condições necessárias para o pleno exercício da cidadania. Portanto, os acusados, em especial os dois réus confessos (Ezequiel Valensuela e Paulino Lopes), agiram de acordo com uma lógica cultural própria, segundo a qual não há ilicitude na necessidade de agir energicamente em defesa da vida e da terra de uma coletividade indígena. Eles assim o fizeram para salvaguardar a comunidade de Passo Piraju do que entenderam ser grandes perigos advindos da presença de estranhos armados e agressivos em seu território. Somente depois da ação souberam tratar-se de policiais civis.

Além disso, ainda hoje os acusados não se sentem ou não se percebem totalmente integrados à sociedade nacional, quer dizer, ao mundo dos karai ou não-índios. Todos eles tampouco demonstraram qualquer interesse em uma integração desse nível, isto é, de uma integração a ponto de perderem sua distintividade étnica, sua indianidade, ou de abandonarem suas comunidades e se transferirem em definitivo para as cidades. Isto não significa que os réus sejam "arredios" aos contatos interétnicos e às trocas culturais com os não-índios. Também não significa que sejam portadores de alguma anomalia mental, que não tenham inteligência e humanidade ou que não possuam sentimento de brasilidade. $\mathrm{Na}$ verdade, sentem-se excluídos da comunhão nacional e submetidos à sociedade envolvente e não integrados a ela.

Todos os réus são oriundos de grupos indígenas que não estavam ou não estão acomodados no interior das cidades, mas que possuem uma organização social e uma cultura que os distinguem da sociedade nacional, as quais norteiam suas ações e seu entendimento sobre o mundo. Por este motivo constantemente são vistos como 
"diferentes", e não como "iguais", para grande parte da população não-indígena regional. Isto explica o porquê de serem frequentemente chamados de "bugres". Para eles e para os indígenas em geral este termo racista é altamente etnocêntrico, pejorativo e discriminatório, pois não reconhece a humanidade e a identidade étnica que possuem, muito menos valoriza seus usos, costumes e tradições culturais.

$\mathrm{Na}$ conhecida enciclopédia virtual Wikipédia, disponível na Internet e visitada diariamente por milhares de pessoas em vários países do mundo, consta o seguinte conceito de "bugre":

\begin{abstract}
Bugre é a denominação dada a indígenas de diversos grupos do Brasil, por serem considerados sodomitas pelos europeus. A origem da palavra vem do francês bougre, que de acordo com o dicionário Houaiss possui o primeiro registro no ano de 1172 e significa "herético", que por sua vez vem do latim medieval (século VI) bulgàrus. Como membros da igreja greco-ortodoxa, os búlgaros foram considerados heréticos, e o emprego do vocábulo para denotar a pessoa indígena liga-se à ideia de "inculto, selvático, não cristão" - uma noção de forte valor pejorativo'.
\end{abstract}

Ratifica-se, portanto, que ao tempo da ação os réus que participaram dos atos agiram de acordo com uma lógica cultural própria, segundo a qual é moralmente correto agir em legítima defesa de seus lares, de seu território, de suas vidas e da vida de outros membros da comunidade de Passo Piraju. Eles repeliram com veemência os três estranhos por eles confundidos com "jagunços" ou "pistoleiros", os quais pensaram estar a serviço de fazendeiros locais ou de pessoas aliadas a eles para lhes fazer mal. A comunidade de Passo Piraju apontou o produtor rural Esmalte Barbosa Chaves e seu filho, Beline Nascimento Chaves, como sendo as principais pessoas com quem mantém relações conflituosas desde o ano de 2004. Esta explicação faz parte da memória social coletiva de uma coletividade indígena e não somente da memória de alguns dos acusados?.

A partir de 2004 os indígenas se estabeleceram no interior da Fazenda Campo Belo, em uma área de 40,8 hectares, cuja permanência foi assegurada por autorização judicial: a decisão suspensiva proferida em face ao Agravo $n^{\circ}$. 2006.03.00.035892-7, interposto pelo Ministério Público Federal. Desde então passaram a reivindicar de maneira mais contundente a identificação, demarcação e homologação de uma terra

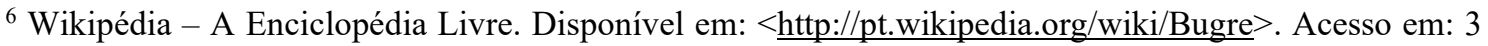
mai. 2008.

${ }^{7}$ Maiores detalhes sobre o histórico da ocupação indígena na região de Porto Cambira constam no seguinte relatório anexo às folhas 563-572 dos Autos: THOMAZ DE ALMEIDA, Rubem F. 2004. Relatório de visita ao acampamento de Porto Cambira, Dourados (MS), onde estão os grupos macrofamiliares Guarani-Kaiowa que reivindicam antigo tekoha denominado Passo Piraju. Rio de Janeiro: FUNAI (não publicado).
} 
indígena na região de Porto Cambira. Entendem que a morte dos dois policiais civis e os ferimentos causados a um terceiro foram uma fatalidade ocorrida em um tenso cenário marcado por conflitos fundiários ligados à disputa pela terra.

Durante os trabalhos periciais os indígenas Ezequiel Valensuela e Paulino Lopes, que são da etnia Kaiowa e pouco dominam a língua portuguesa, explicaram em seu idioma materno, o guarani, que participaram diretamente da luta contra os policiais, deferindo-lhes golpes de faca. Isto teria acontecido em um espaço de tempo muitíssimo curto. Somente depois do acontecido souberam tratar-se de policiais civis. Os demais acusados - à exceção de Hermínio Romero, com quem não foi possível realizar a perícia pelo fato de o mesmo estar desaparecido negaram repetidas vezes que tenham tido participação decisiva na morte dos policias.

Esta explicação dos fatos foi feita amiúde por vários motivos, conforme explicado a seguir.

Primeiro, pelo temor de serem condenados e virem a passar novamente pela traumática experiência que tiveram quando permaneceram detidos na sede do DOF (Departamento de Operações de Fronteira), na Polícia Federal e na PHAC (Penitenciária Harry Amorim Costa). Estão registrados em suas memórias os detalhes do tratamento desumano, sobremaneira as sessões de tortura que sofreram no DOF e na PHAC, quando, respectivamente, da tomada dos primeiros depoimentos à Polícia Civil e por ocasião das primeiras semanas em que permaneceram apenados naquele presídio de segurança máxima. Alguns detalhes desses momentos traumáticos foram relatados ao Juízo, ao Ministério Público Federal, a entidades de defesa dos direitos humanos e a instituições indigenistas, conforme explicado adiante. Constatou-se, à luz da ciência antropológica, que suas narrativas não estão situadas em um plano mitológico, tampouco que fazem parte de qualquer tipo de explicação fantástica, imaginativa e inventiva de realidades não vivenciadas pelos acusados. Pelo contrário, a riqueza dos detalhes descritos atesta tratar-se do registro de experiências traumáticas ocorridas em suas histórias de vida, as quais apontam claramente para o abuso de poder por parte de autoridades policiais e carcerárias, e para a explícita violação dos direitos humanos. Mais adiante esta questão será tratada com maior detalhamento.

Segundo, por entenderem que os principais ferimentos causados aos três policiais advieram dos golpes de faca a eles desferidos e não necessariamente de outras lesões que teriam sofrido durante o conflito. No caso do policial Ronilson Guimarães Bartiê, os dois réus confessos afirmaram que o projétil da espingarda calibre 12 que o atingiu na região posterior do joelho direito adveio de uma arma usada pelo policial Emerson José Gadani. No momento dos conflitos, o referido servidor público teria apontado a arma de grosso calibre em direção a eles. Mas ao perceberam sua ação, os dois se esquivaram rapidamente, instante em que alguém poderia ter tentado segurar ou tomar a espingarda do policial para desviar sua pontaria, de tal forma que quando a arma foi disparada o projétil atingiu involuntariamente o policial Ronilson Guimarães Bartiê. 
Terceiro, porque compreendem que todo o sofrimento que tiveram e que estão a enfrentar até o momento, devido ao tratamento desumano que afirmam ter recebido e a outros desdobramentos da ação, tem sido uma punição austera e sumariamente sentenciada. Entendem que esta sentença partiu de instituições policiais, funcionários da PHAC, setores da imprensa local, amplos segmentos da sociedade envolvente e do próprio sistema judiciário, sem terem tido direito à defesa. Acrescenta-se a esta situação o fato de o réu Hermínio Romero ter desaparecido misteriosamente da aldeia de Passo Piraju assim que foi solto da prisão de Jateí, na tarde de 02/04/2007, após um ano de prisão em regime fechado ${ }^{8}$. Este fato, acontecido no início de abril de 2007, é apontado pela comunidade indígena como um provável assassinato feito por policiais ou por pessoas assim identificadas por eles, ou que se fizeram passar como tais, em represália aos acontecimentos do dia 1\%/04/2006. Situação semelhante aconteceu com Antônio da Silva, esposo de Teodocia Savala e tio de Valmir Júnior Savala, indígena kaiowa desaparecido no dia 03/04/2006, quando policiais de diferentes corporações foram à aldeia em busca dos autores da ação e o teriam encontrado à beira do rio Dourados, onde pescava. Na ocasião muitos indígenas ouviram disparos de armas de fogo vindos do lugar onde ele estava e, em seguida, alguns gritos de dor. Minutos depois policiais deixaram a beira do rio, subiram o barranco em direção à escola da aldeia e passaram em frente a vários indígenas com um sorriso no rosto. Este gesto foi interpretado por muitos indígenas como uma satisfação dos policiais pelo cumprimento de uma missão, a de fazer justiça com as próprias mãos e dessa forma vingar os dois colegas mortos e o ferido. Quando foram até a beira do rio encontram apenas um dos dois sapatos que Antônio da Silva usava naquele dia. Em decorrência desses acontecimentos alguns membros da comunidade ceifaram suas próprias vidas por enforcamento. São eles: Teresa Murilha, de uns 22 anos de idade e esposa de Paulino Lopes, falecida em 14/10/2006; Valdinei de Souza, com cerca de 30 anos de idade, sobrinho de Carlito de Oliveira e cunhado de Márcio da Silva Lins, morto em 18/02/2007; e Oséias, um adolescente de aproximadamente 14 anos de idade e filho de um casal de índios da Reserva Indígena de Dourados. Os suicidas pensavam que seus parentes não regressariam mais, o que foi motivo de intensa saudade, chamada poroechaga'u. Somou-se a isto a forma elegíaca, denominada ñemyrõ, com que os Guarani e Kaiowa comumente reagem quando se sentem objeto de descaso, abandono, agressividade e falta de alternativas. Trata-se de uma espécie de tristeza, angústia e fúria reprimida interiormente que os motivaram a atentar contra suas próprias vidas. Outros motivos que os levaram à morte foram: a falta dos meios materiais para a sobrevivência física das famílias dos detidos e a extrema dificuldade de liderar, na ausência de seu principal líder, a comunidade de Passo Piraju em um

\footnotetext{
${ }^{8}$ A soltura dos réus, por decisão do Supremo Tribunal de Justiça, foi amplamente divulgada pela imprensa regional e nacional, como se percebe na matéria Índios acusado de matar policiais civis são soltos, divulgada pela redação do jornal virtual Capital do Pantanal. Disponível em: $<$ http://www.capitaldopantanal.com.br/index.php?sPagina $=$ cpt002_noticia\&iNoticia $=22361 \&$ sCanal=>. Acesso em: 19 jun. 2008.
} 
clima de medo e incertezas. Morreram ainda após o ocorrido, porém não por suicídio e sim por males advindos da ausência dos pais presos ou desaparecidos, Mariluce da Silva, filha de Antônio da Silva, e Celso Murilha Lopes, filho de Tereza Murilha e Paulino Lopes, este último falecido com cerca de 1 ano e meio de idade.

Quarto, pela ciência de que se os acusados permanecerem detidos em instituições penais estarão impedidos de participar da vida familiar (criação de seus filhos e proteção de seus cônjuges) e da vida social e política na aldeia. Isto gerará muitos impactos negativos de grande magnitude à coletividade indígena, como a desarticulação de várias famílias e da própria comunidade de Passo Piraju. Para os réus a separação de suas famílias seria como uma condenação à pena capital, o que seguramente poderá levar alguns a cometerem suicídio no cárcere.

Quinto, por terem a percepção de que muitos deles, em especial os seis primeiros réus presos (Jair Aquino Fernandes, Lindomar Brites de Oliveira, Marcio da Silva Lins, Paulino Lopes, Sandra Arevalo Savala e Valmir Junior Savala), terem sido interrogados durante sessões de tortura física e psicológica para assumirem a autoria das ações. Entendem que foram forçados a assinar os depoimentos tomados pela delegada Magali Leite Cordeiro Pascoal, pois isso se deu sob pressão psicológica e tratamento desumano, inclusive com ameaças de morte e sessões de espancamento e eletrochoque, conforme explicado em detalhes mais à frente.

Sexto, e último, porque seis dos acusados - à exceção dos dois réus confessos e de um outro desaparecido - alegam que foram presos de maneira arbitrária e violenta por policiais que chegaram à aldeia de Passo Piraju em busca dos culpados pela ação, com o intuito de prendêlos e apresentá-los à sociedade nacional e à imprensa local. No caso da ré Sandra Arevalo Savala, da etnia Kaiowa e que também se expressa com muita dificuldade na língua portuguesa, cumpre explicar que ela e outras pessoas da comunidade de Passo Piraju, como os demais réus e a liderança Plácida Brites de Oliveira, disseram de maneira clara e uníssona que a citada delegada não lhe havia dado voz de prisão quando a levou para Dourados. Apenas convidou-a insistentemente a "colaborar" com a Polícia Civil e prestar seu depoimento sobre os fatos. Segundo explicou, na passagem do dia $1^{\circ}$ para o dia 02/06/2008, ao chegar ao DOF acabou sendo presa e cruelmente torturada por um policial militar de pele morena, quem muitas vezes a chamou de "covarde", "vagabunda" e "assassina". Durante as sessões de tortura a própria delegada teria dito o seguinte: "Dá mais uma 'paulada' aí que ela conta!". Ela explicou que a maioria dos socos e tapas que levou foi dada na região da cabeça (couro cabeludo), embora tenha recebido murros no estômago e tenha sido arremessada com muita força contra a parede. Disse ainda que "Só Deus que sabe isso aí!", referindo-se ao fato de existir uma onipresença divina que testemunhou todos os esses fatos. E mais, que ela e os outros indígenas presos sobreviveram a tudo isso porque não era destino deles morrer no cárcere: "A gente no morre porque no morre lá memo!". Após as torturas que afirma categoricamente ter sofrido na sede do DOF, sob as ordens da delegada Magali Leite Cordeiro Pascoal, a referida indígena 
explicou que passou frio na cela e sentiu-se muito mal no dia seguinte ao de sua prisão. Teve muitas dores pelo corpo e sentiu-se como se tivesse "descido" sua menstruação, o que de fato aconteceu. Estando menstruada foi levada para a sede da Polícia Federal em Dourados, onde também passou frio, mas não apanhou de policial algum. Ao lado da cela onde ficou detida havia um não-índio, quem a ajudou dando-lhe sabonete e papel higiênico para sua higiene íntima e uma blusa para se proteger do frio. Na PHAC ficou presa com outras mulheres e delas recebeu tratamento respeitoso e ajuda o tempo todo, algo que credita a uma solidariedade comum ao gênero feminino, independentemente das diferenças culturais. Permaneceu por mais de 30 dias sem sua menstruação cessar, o que a deixou bastante debilitada. Disse que também foi tratada com respeito no período em que ficou detida no Presídio de Rio Brilhante, tanto pelas colegas de cela quanto por agentes carcerários e demais funcionários da casa de detenção. Durante o período de um ano em que Sandra Arevalo Savala permaneceu presa, seus três filhos foram criados como guácho (filhos adotivos) pela sua avó materna, Florentina Barbosa, quem também é sua mãe de criação porque sua mãe biológica faleceu quando ela ainda era muito pequena. Esta sua avó é moradora da aldeia Guasuty, em Aral Moreira, mas nasceu em Passo Piraju na primeira metade do século XX, o que explica seu vínculo com a região. Atualmente a ré se sente bastante deprimida: chora com frequência e constantemente é acometida de pensamentos ruins, inclusive os de suicídio por enforcamento. Afirma que sua saúde nunca mais foi a mesma depois da tortura que sofreu, pois sente fortes dores pelo corpo, sobretudo na cabeça, tem câimbras nas pernas e sua menstruação ficou desregulada, frequentemente a durar de uma a duas semanas de fluxo. Ela não pretende mais voltar a morar em Passo Piraju, localidade que lhe traz más recordações por conta dos acontecimentos que envolveram os policiais civis.

É praticamente consensual entre os oito réus periciados e para muitos outros membros da comunidade de Passo Piraju que Sandra Arevalo Savala é uma pessoa que nada teve a ver com a agressão direta perpetrada contra os policiais civis, até porque neste tipo de ação não é comum haver a participação imediata de mulheres. Deve ser registrado, ainda, que no momento em que as viaturas policiais e do Corpo de Bombeiros chegaram ao local do conflito, a ré retirou da estrada um revólver que ali estava jogado. Fez isso para evitar que os veículos passassem por cima da arma de fogo, o que poderia causar algum disparo acidental. Disso resultou um julgamento prévio, por parte de agentes policiais presentes na ocasião, de que ela teria participado diretamente na ação.

No dia prisão dos primeiros réus, $1 \% / 04 / 2006$, um indivíduo nãoíndio, conhecido pela comunidade de Passo Piraju como Cacá, esteve no local da ação no momento em que os policiais ali se encontravam para prender os autores da agressão. Trata-se da testemunha de acusação Carlos Eduardo Macedo Marquez, apontada por vários réus como sendo aliado de Esmalte Barbosa Chaves e genro do produtor rural e deputado estadual José Roberto Teixeira, mais conhecido como Zé Teixeira, do 
partido DEM (Democratas). Segundo as narrativas dos indígenas, naquela ocasião o referido cidadão estava enfurecido e a todo instante pedia em voz alta para que os policiais lhe dessem alguma arma de fogo para ele mesmo acabar com a "raça desses bugres". Sua fúria era tão grande que parecia histeria, pois ele teria sido grosseiro até mesmo com alguns policiais presentes na ocasião.

De todo modo, os seis motivos retro apresentados são mais bem compreendidos através das informações e análises apresentadas no decorrer do presente laudo pericial.

À época dos fatos todos os nove réus desconheciam que policiais civis pudessem trabalhar à paisana (sem uniforme, crachá ou qualquer tipo de identificação) nos finais de semana, e que em geral assim o fazem de forma discreta durante a investigação de crimes ocorridos. Também desconheciam o fato de esses servidores públicos poderem usar veículos diferentes dos conhecidos "camburões" da Polícia Militar e da Polícia Federal, por eles reconhecidos como as viaturas oficiais usadas por policiais no exercício de suas funções. Exemplo disso é o caso das viaturas devidamente caracterizadas usadas por policiais e funcionários da FUNAl durante a execução da Operação Sucuri em Dourados, oficialmente iniciada a partir do dia 19/07/20049.

Os réus e muitos outros membros da comunidade de Passo Piraju percebem a Polícia Militar como uma instituição que geralmente se faz presente em suas vidas durante o cumprimento de decisões judiciais para a reintegração de posse, por vezes repreendendo-lhes com o uso de práticas que consideram violentas. A instituição lembra a antiga Polícia da "Captura" que existiu na primeira metade do século XX, quando forças policiais do antigo estado de Mato Grosso combateram os grupos de "bandidos" e "bandoleiros" que difundiam medo e terror na região fronteiriça com o Paraguai, conforme explicado na resposta apresentada ao quesito de $\mathrm{n}^{\circ}$. 3.2, formulado pelo Ministério Público Federal, Procuradoria da República em Dourados. Por outro lado, os acusados possuem melhor conceito da Polícia Federal, instituição por eles vista como aquela que muitas vezes tem atuado na proteção dos povos indígenas e no cumprimento de decisões judiciais que Ihes são favoráveis. No caso da Polícia Civil, até então eles pouco ou nada sabiam sobre suas atribuições constitucionais, sobretudo a respeito do fato de se tratar de uma polícia judiciária que atua na apuração de infrações penais; também não tinham tido qualquer tipo de conflito com funcionários públicos desta corporação. Atualmente, no entanto, após os acontecimentos que os

\footnotetext{
${ }^{9}$ Segundo consta no jornal virtual Rota Brasil Oeste, a Operação Sucuri foi bem aceita por grande parte da população da Reserva Indígena de Dourados. Inicialmente integraram esta operação dois delegados da Polícia Federal, dois delegados da Polícia Civil, dois policiais militares e funcionários da FUNAI (vide matéria Funai e PF fazem varredura em aldeias de Dourados, de 16/07/2004. Disponível em: $<$ http://www.brasiloeste.com.br/noticia/1068/>. Acesso em: 19 jun. 2008). O termo Operação Sucuri é a mesma denominação da última grande ação planejada e executada pela forças armadas brasileiras para derrotar a chamada a "Guerrilha do Araguaia", em 1974. A sucuri (Eunectes spp.) é a maior cobra que existe na América do Sul, conhecida por apertar e matar suas presas por asfixia, para depois se alimentar delas.
} 
levaram à prisão, percebem-na como uma instituição extremamente violenta, etnocêntrica e preconceituosa em relação aos povos indígenas, de modo especial o Primeiro Distrito Policial de Dourados.

Segundo observado nos Autos e noticiado pela imprensa local, na tarde do dia 1\%/04/2006, os policiais civis Ronilson Guimarães Bartiê (morto), Rodrigo Pereira Lorenzatto (morto) e Emerson José Gadani (ferido) teriam se deslocado até a localidade de Porto Cambira, em cumprimento a uma ordem recebida da delegada Magali Leite Cordeiro Pascoal. Sua presença ali teria sido para procurar um indivíduo não-índio, chamado Wilson Rodrigues da Silva, que estaria escondido na região e foragido da Lei. Sabe-se, no entanto, que os Guarani e Kaiowa não têm por costume, hábito ou tradição acolher não-índios foragidos da Justiça em suas aldeias, dando-lhes guarida ou esconderijo. Todo modo, o citado cidadão foi apontado como o assassino do pastor evangélico Sinforiano Ramirez, seu sogro, ocorrido na noite do dia anterior, 31/03/2006, na cidade de Dourados. Esta morte foi consequência de três tiros de arma de fogo disparados contra o sacerdote cristão no interior da casa de Andréia Cristina dos Santos Araújo, sua ex-companheira e enteada da vítima ${ }^{10}$.

Matérias jornalistas divulgadas na época, e ainda disponíveis na Internet, informaram que no dia 28/08/2007 o referido indivíduo foi condenado a 14 anos de prisão pelo crime qualificado que cometeu. Quando os réus do sexo masculino estavam presos no Presídio de Jateí, encontraram com Wilson Rodrigues da Silva, quem até então desconheciam. Segundo ele mesmo teria explicado aos acusados, no dia dos acontecimentos seu advogado informou à Polícia Civil, por meio de uma ligação telefônica, que o apresentaria à Lei na segunda-feira seguinte, dia 03/04/2008, e que, portanto, em princípio não havia motivos para o envio de agentes policiais à região de Porto Cambira.

O sítio eletrônico Midiamax News noticiou o episódio que envolveu os três policiais às $12 \mathrm{~h} 02 \mathrm{~min}$. do dia 03/04/2006, através da matéria intitulada Zeca diz que índios premeditaram emboscada a policiais civis, na qual o então governador do estado, José Orcírio Miranda dos Santos, teria emitido juízo de valor sobre os fatos e por este motivo foi denunciado pelo Ministério Público Federal por calúnia e difamação"

De acordo com a assessoria de imprensa da Polícia Civil, os agentes Rodrigo Pereira Lorenzatto, 26 anos, Ronilson Guimarães Bartie, 36 anos, e Emerson José Gadani, 33 anos, foram até o acampamento investigar a denúncia de que Wilson Rodrigues da Silva, autor de um homicídio ocorrido no dia anterior, estaria escondido no local. Eles teriam até tentado fugir dos índios mas foram cercados

\footnotetext{
${ }^{10}$ Vide matéria Acusado de matar pastor é condenado a 14 anos de prisão, divulgada em 29/08/2007 no sítio eletrônico Agora MS. Disponível em: $<$ http://www.agorams.com.br/index.php?ver=ler\&id=109632>. Acesso em: 27 abr. 2008.

${ }^{11}$ Vide matéria Zeca do PT é denunciado pelo MPF por calúnia e difamação, divulgada em 06/08/2007 no sítio eletrônico Agora MS. Disponível em:

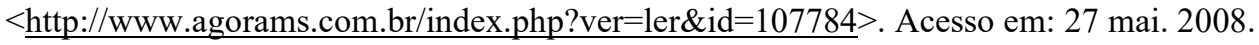


por dezenas deles quando chegaram às margens da MS$156^{12}$. (transcrição ipsis litteris)

No mesmo dia, porém um pouco mais cedo, às $7 \mathrm{~h} 21 \mathrm{~min}$. , o mesmo eletrônico também divulgou a matéria Indígenas são autuados em fragrante por matarem dois policiais em Dourados:
A ação ocorreu ontem, por volta das 16 horas, na MS- 156, na saída de Dourados para Caarapó. Os três policiais foram espancados, esfaqueados e baleados. A Polícia Civil informou que os três policiais foram vítimas de uma emboscada após perseguição ocorrida no interior da aldeia.
Conforme a polícia, eles faziam buscas para tentar localizar Wilson Rodrigues da Silva, acusado pelo assassinato do pastor evangélico Sinforiano Ramirez, 42 anos, morto a tiros na noite desta sexta-feira. Segundo a Polícia Civil, os três policiais teriam cortado caminho pela aldeia para chegar à uma fazenda onde, segundo denúncia, Wilson estaria escondido. Os policiais estavam em uma viatura descaracterizada.
A polícia informou que eles foram perseguidos por uma multidão de índios e quando chegaram à MS-156 foram surpreendidos por indígenas nos dois lados da pista. Um motorista que passava pelo local acionou a polícia que compareceu com os bombeiros. Segundo a polícia, os policiais teriam sido confundidos com seguranças de fazendeiros e por isso foram perseguidos e atacados pelos índios ${ }^{13}$. (transcrição ipsis litteris)

Nesta matéria jornalística, a Polícia Civil teria confirmado à imprensa regional que os policiais "teriam cortado caminho pela aldeia para chegar à [sic.] uma fazenda onde, segundo denúncia, Wilson estaria escondido", e que "teriam sido confundidos com seguranças de fazendeiros e por isso foram perseguidos e atacados pelos índios". Na ocasião foi divulgada uma fotografia do réu Carlito de Oliveira, líder político da comunidade de Passo Piraju, que segue apresentada na sequência.

\footnotetext{
${ }^{12}$ CASTRO, Nakienka; FILHO, Hélio. 2006. Zeca diz que índios premeditaram emboscada a policiais civis. Disponível em: $<$ http://www.capitaldopantanal.com.br/index.php?sPagina $=$ cpt002 noticia\&iNoticia $=4755 \&$ sCanal $=>$. Acesso em: 24 mai. 2008.

${ }^{13}$ Vide matéria Indígenas são atuados em flagrante por matarem dois policiais em Dourados, divulgada em 03/04/2006 no sítio eletrônico Capital do Pantanal. Disponível em: $<$ http://www.capitaldopantanal.com.br/index.php?sPagina $=$ cpt002_noticia\&iNoticia=4722\&sCanal $=>$. Acessado em: 24 mai. 2008.
} 
Figura 1: Fotografia de Carlito de Oliveira, de autoria de Hedio Fazam, do jornal $O$ Progresso, divulgado no sítio eletrônico Midiamax News em 03/04/2006.

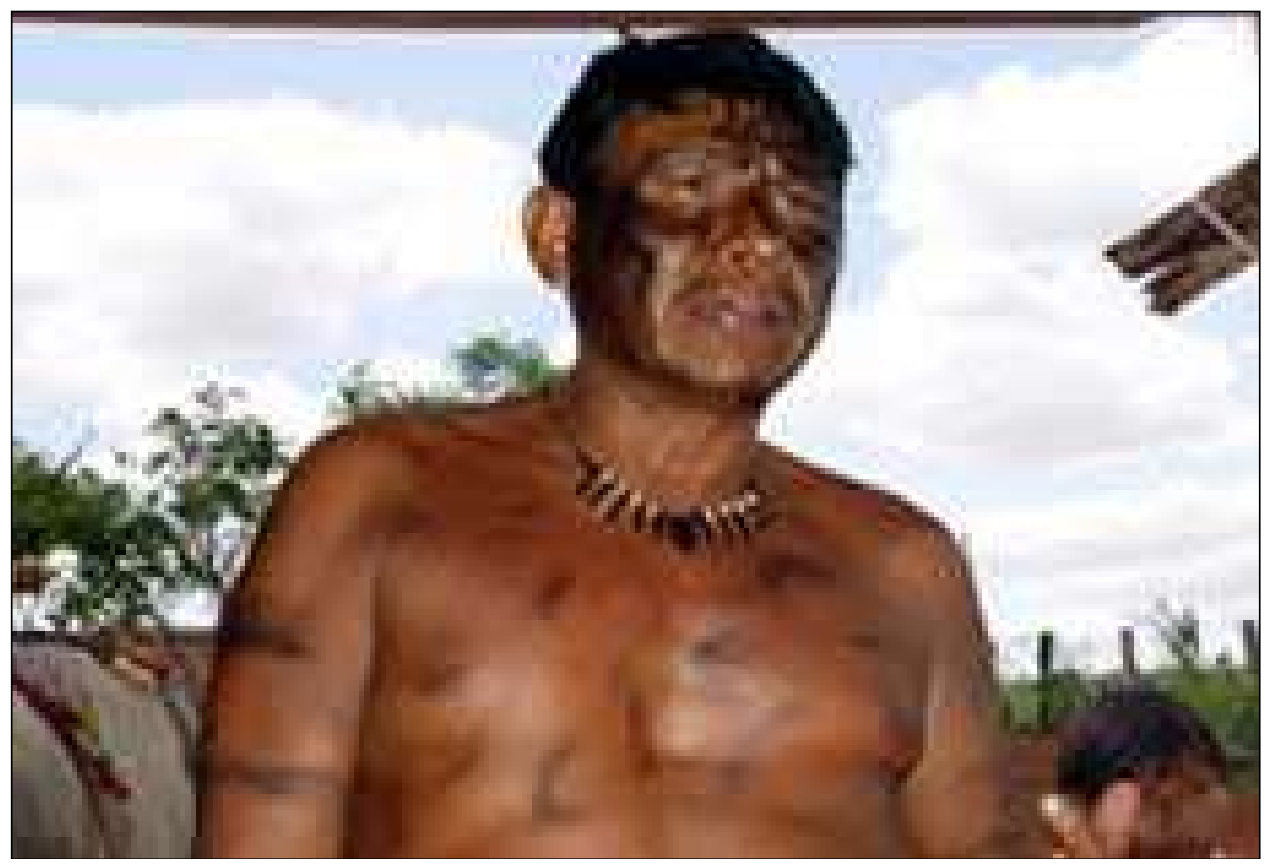

A fotografia divulgada de Carlito de Oliveira, em que o indígena aparece com o rosto e outras partes do corpo pintadas de preto e vermelho - uma forma tradicional da manifestação de distintividade étnica -, sugere que o acusado estaria pronto para a guerra. Imagens desse tipo foram e são usadas com frequência pela mídia regional, em especial pelo jornal $O$ Progresso, para divulgar mensagens depreciativas sobre os índios ${ }^{14}$. No caso em apreço, o retrato contribuiu para reforçar um imaginário coletivo voltado para atribuir pinturas corporais a situações de belicosidade dos indígenas contra a sociedade envolvente.

Segundo apontado pelos réus e por vários outros membros da comunidade de Passo Piraju, na tarde do dia 1\%/04/2006, três policiais civis adentraram armados e descaracterizados no interior da área onde está instalada a aldeia. Estavam sem uniforme, não usavam como meio de transporte uma viatura do tipo "camburão" e portavam armas de fogo. Adentrarem na área pela principal via de acesso à aldeia, no ponto localizado nas coordenadas UTM 737172E/7518750N, conforme indicado na Fotografia de $\mathrm{n}^{\circ}$. 1 do Laudo Pericial $\mathrm{n}^{\circ}$. 11.710/DO, constante na folha $n^{\circ} .212$ dos Autos ${ }^{15}$. Entretanto, eles não teriam se

\footnotetext{
${ }^{14}$ Uma pesquisa inédita, intitulada A representação da desnutrição indígena nos jornais de Dourados (1999-2005), que versa sobre a relação entre a imprensa escrita local e a questão indígena regional, está sendo desenvolvida pela jornalista Priscila Viudes no Programa de Pós-graduação em História da UFGD. Deverá ser concluída e divulgada em 2009 sob forma de dissertação de mestrado. Os resultados preliminares desse estudo comprovam a parcialidade com que o jornal O Progresso e certos repórteres e jornalistas de Dourados tratam da questão indígena em Mato Grosso do Sul, a exemplo da desnutrição infantil e dos conflitos fundiários mantidos com produtores rurais.
}

15 DOURADO, Jean Cléber S.; VIANA, Eraldo F. 2006. Laudo Pericial no . 11.710/DO. Dourados: Coordenadoria-Geral de Perícias, Instituto de Criminalística "Hercílio Macellaro", Núcleo Regional de Dourados, 15p. (não publicado) 
apresentado às lideranças indígenas locais, tampouco explicaram a natureza dos trabalhos que estariam a realizar na região ou mesmo solicitaram permissão para trafegar de carro naquele território.

Os indígenas observaram que os policiais estavam no interior de um automóvel pequeno - se comparado a uma camioneta - e de cor escura, denominada em guarani de hũ. As características por eles apresentadas vão ao encontro dos dados que constam nos Autos, folhas 213 e 214, ou seja, veículo marca Volkswagen, modelo Parati, placa HQH 7231. Quando os referidos servidores públicos entraram com o carro no local onde estava acomodada a comunidade de Passo Piraju, muitos indígenas se assustaram ao vê-los naquele lugar, inclusive mulheres e crianças.

De acordo com informações obtidas junto à comunidade de Passo Piraju, as quais fazem parte da memória social coletiva do grupo, o citado veículo se dirigiu até o final da área da aldeia, precisamente no local em que faz divisa com uma cerca de arame e uma plantação de cana-deaçúcar (coordenadas UTM 737724E/7518764N) (Figura 2). A poucos metros dali, nas coordenadas UTM 737740E/7518690N, morava o kaiowa Nilson Duarte e sua família, atualmente residentes na aldeia Te'ýi kue, em Caarapó (Figura 3). Este indígena estaria a consertar um aparelho de som quando também foi surpreendido pela presença daqueles estranhos armados. O susto que muitos tomaram foi grande por conta da surpresa que os policiais causaram à comunidade e também por conta de algumas manobras bruscas, assim interpretadas pelos indígenas, que teriam sido realizadas com a viatura em movimento na estrada de chão que corta a aldeia. Na ocasião algumas crianças brincavam à margem dessa estrada, em um antigo campinho localizado nas coordenadas UTM $737346 \mathrm{E} / 7518728 \mathrm{~N}$, e também se assustaram com a presença dos intrusos (Figura 4). O mesmo aconteceu com várias mulheres da comunidade, como Isnailda Vilhalva, que correram em direção às crianças - muitas delas seus filhos e netos - para levá-las ao interior de suas residências, onde estariam mais seguras. Logo em seguida dezenas de pessoas ouviram disparos de armas de fogo que partiam dos ocupantes do veículo, quando o mesmo se movimentava para sair da aldeia, em direção à rodovia MS 156. Ninguém soube explicar o porquê dos tiros disparados pelos policiais. Soube-se apenas que um projétil atingiu a parte de baixo do dedão do pé direito do réu Márcio da Silva Lins, da etnia Ofaié, que naquele instante estava a construir o telhado de sua casa com capim sapé. Esta residência estava situada nas coordenadas UTM $737514 \mathrm{E} / 7518725 \mathrm{~N}$ (Figura 5). 
Espaço Ameríndio

Figura 2: Fotografia do local em que a área da aldeia faz divisa com uma cerca de arame e uma plantação de cana-de-açúcar (UTM 737724E/7518764N).

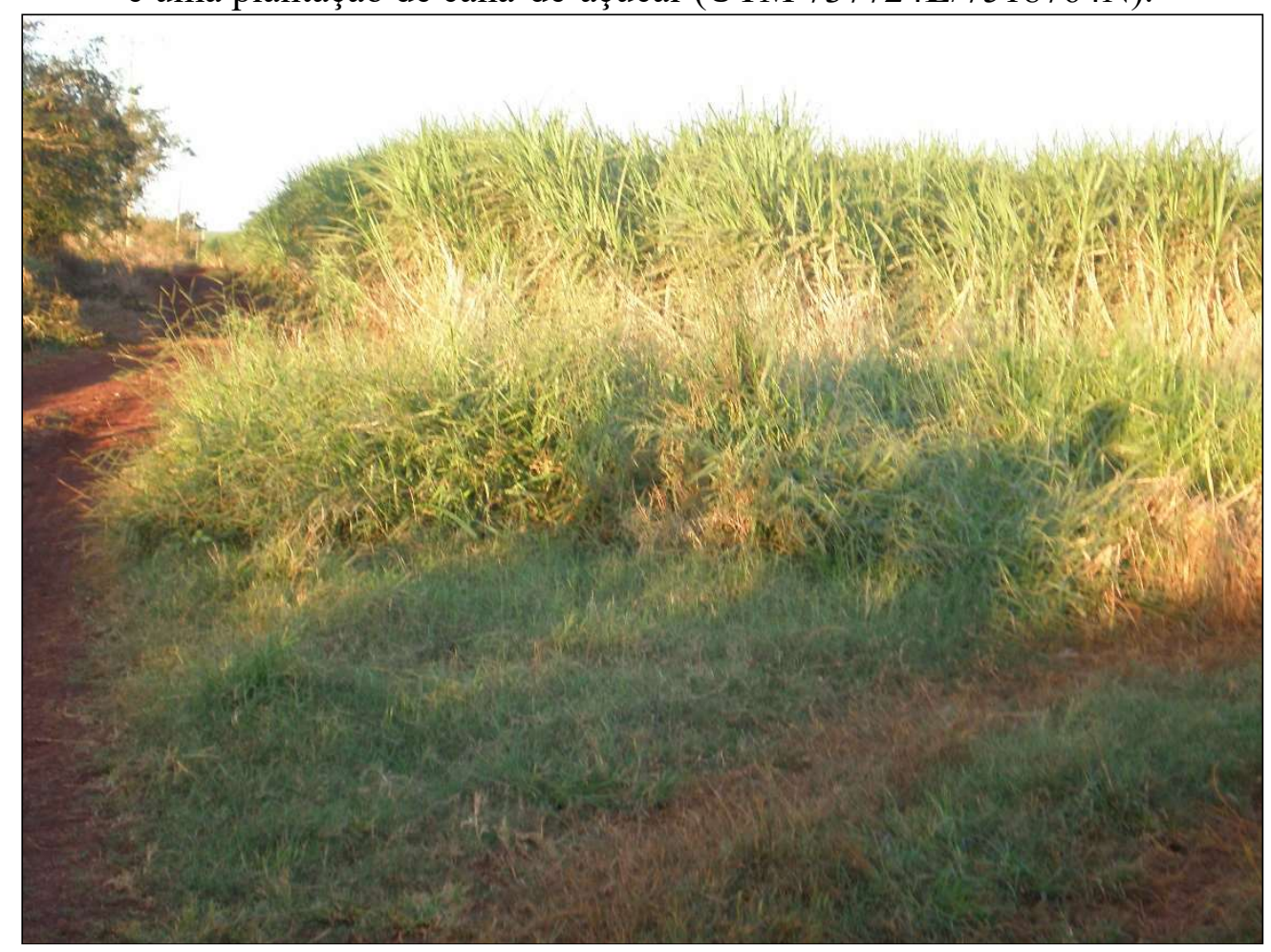

Figura 3: Casa construída no local onde ao tempo da ação morava o indígena Nilson Duarte e sua família (UTM 737740E/7518690N).

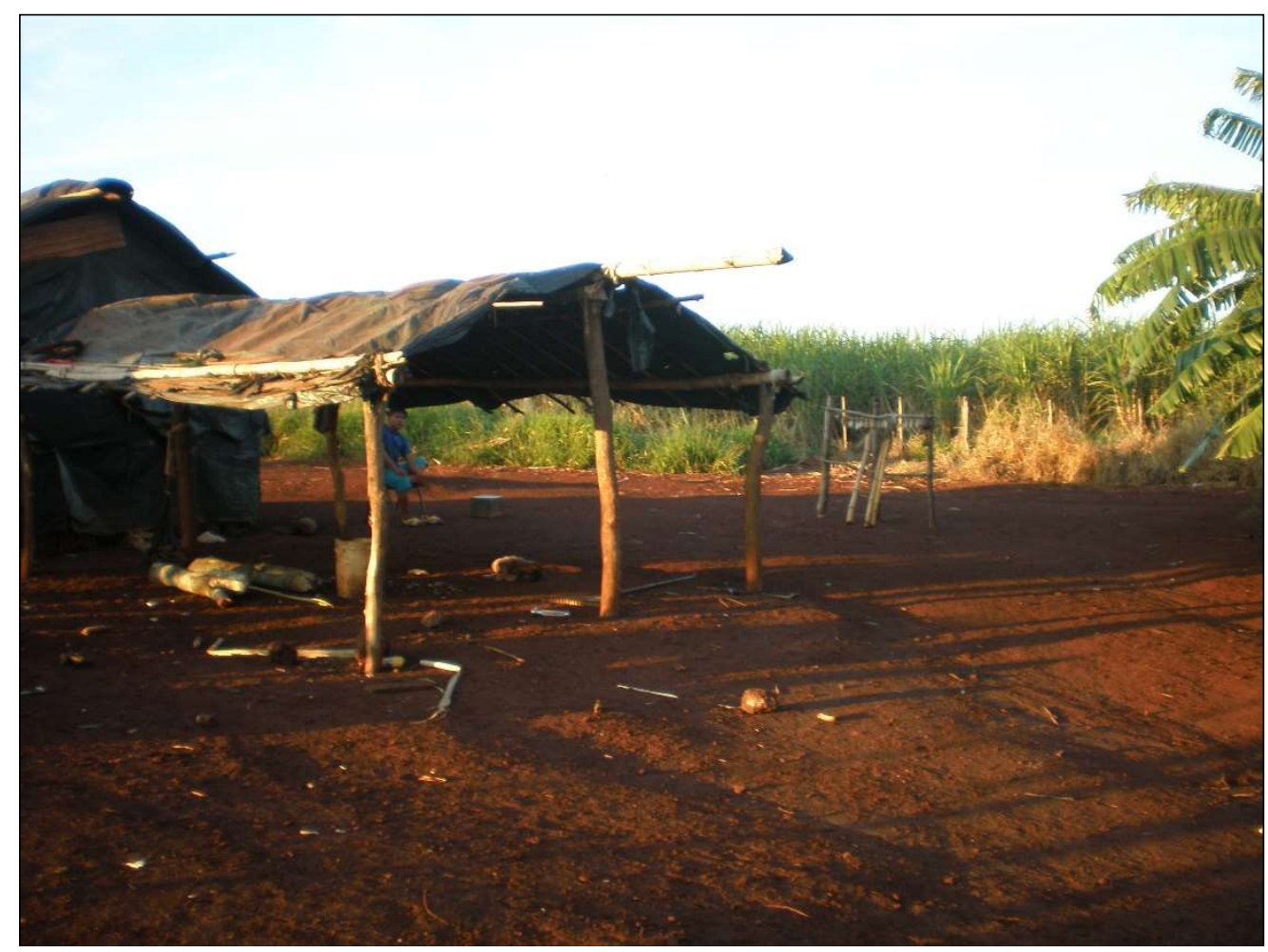


Espaço Ameríndio

Figura 4: Local onde havia um campinho para crianças brincar às margens da estrada que dá acesso ao interior da aldeia (UTM 737346E/7518728N).

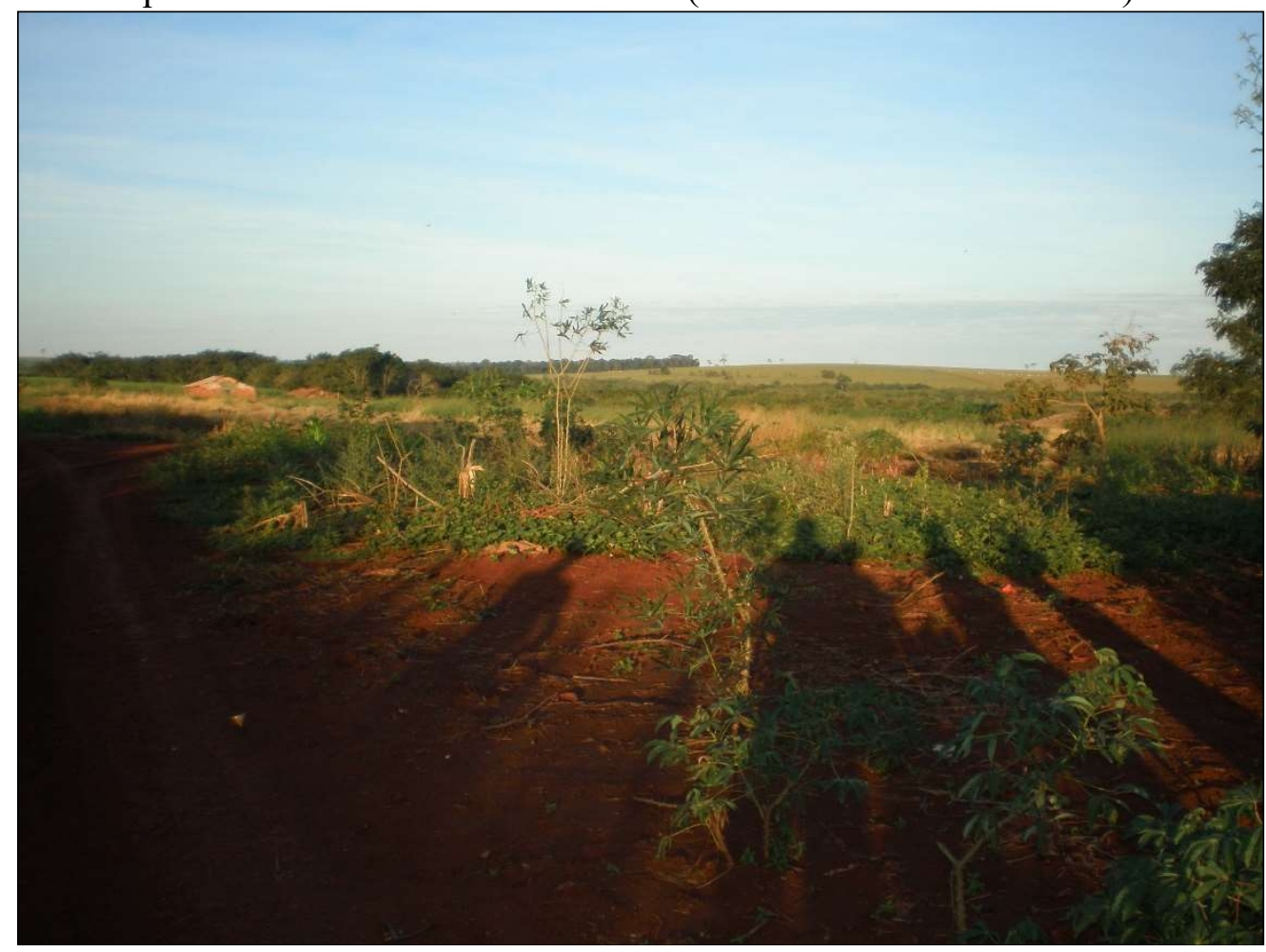

Figura 5: Local onde Marcio da Silva Lins estava a construir sua casa no dia dos acontecimentos (UTM 737514E/7518725N).

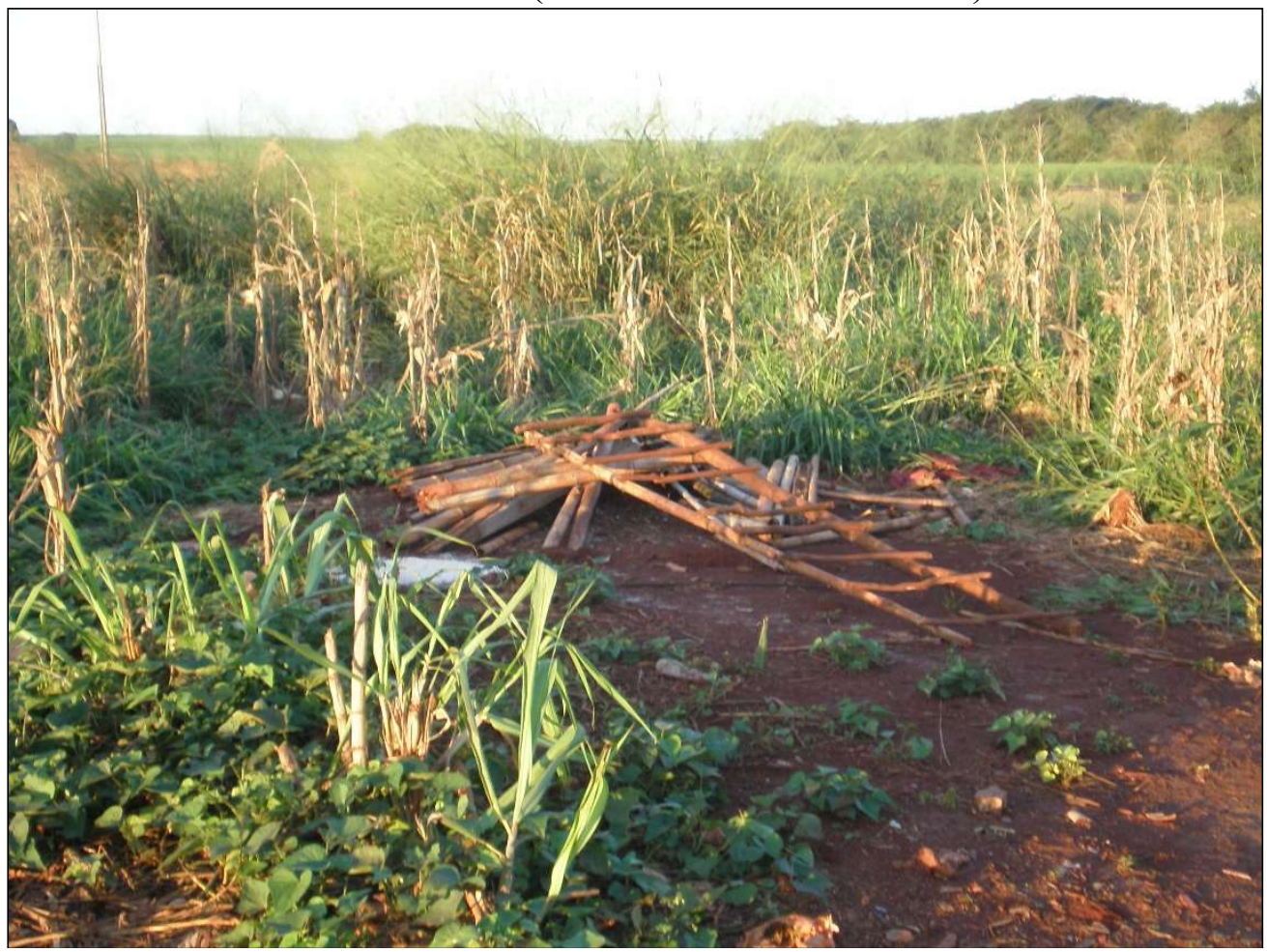

Alguns dos réus e muitas outras pessoas da comunidade de Passo Piraju disseram que no dia 02/04/2006, um dia após a ação, o antropólogo Marcos Homero Ferreira Lima, analista pericial em 
antropologia da Procuradoria da República em Dourados, esteve na área do conflito e tirou fotografias do local. Uma dessas fotografias seria das marcas dos pneus do carro usado pelos policiais civis quando eles estavam no interior da aldeia. O referido cientista social foi procurado pelo perito da equipe e concedeu o arquivo dessas fotografias digitais.

Figura 6: Fotografia digital tirada por Marcos Homero Ferreira Lima no dia 02/04/2006, na qual aparecem as marcas do carro que teria sido usado pelos policiais civis no dia da ação. Trata-se de uma imagem registrada no interior da aldeia de Passo Piraju, no final da estrada que dá acesso à área de acomodação da comunidade, nas proximidades do local onde morava Nilson Duarte e sua família.

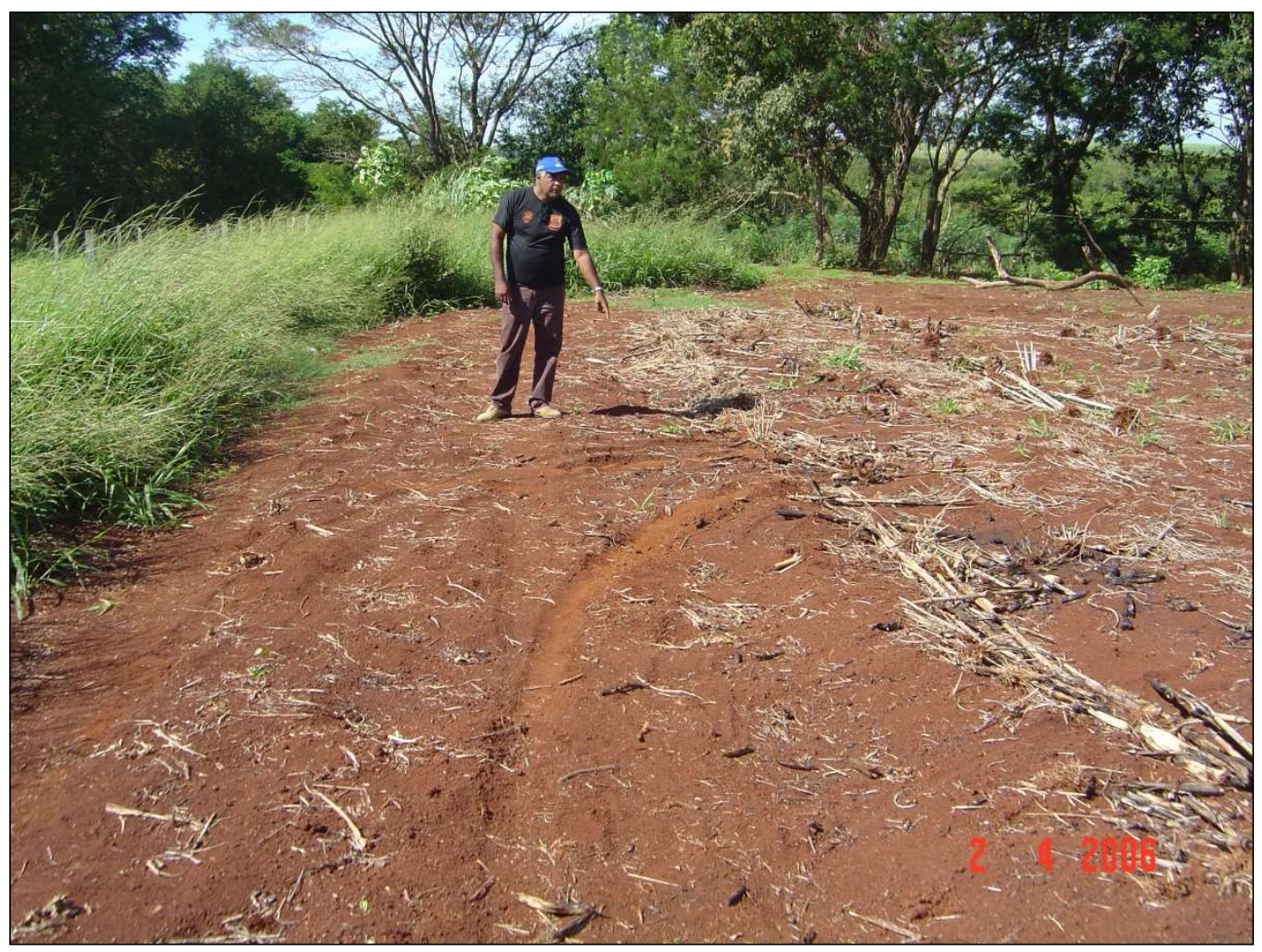

Nesta parte do laudo pericial, torna-se necessário apresentar um esclarecimento pontual sobre a presença do réu Márcio da Silva Lins entre os Guarani e Kaiowa na região de Porto Cambira. Apesar de pertencer à etnia Ofaié, verificou-se que ele foi morar em Passo Piraju porque aceitou o convite que recebeu de sua irmã, Maria Aparecida Lins de Souza, quem à época estava casada com o guarani Valdinei de Souza e morava naquele lugar.

Maria Aparecida Lins de Souza e Valdinei de Souza se conheceram na aldeia ofaié de Brasilândia, onde vivem muitos indígenas das etnias Guarani e Ofaié, e alguns poucos da Kaiowa. Depois de casados eles foram morar em Passo Piraju. Neste caso em particular verifica-se a existência da regra da patrilocalidade, segundo a qual após o casamento a residência do casal é junto à comunidade do marido.

Portanto, ao tempo da ação, Márcio da Silva Lins estava na região de Porto Cambira porque possui vínculos de parentesco e aliança política com pessoas daquela comunidade, em especial com sua irmã e seu 
cunhado. Este caso é emblemático para compreender um pouco da dimensão e da complexidade que envolve uma rede de relações sociais entre os indígenas. No caso em tela, esta rede também se constituiu a partir de relações interétnicas. O referido réu também disse que foi espancado na sede do DOF em Dourados, porém não chegou a receber sessões de eletrochoque. Na PHAC recebeu o mesmo tratamento dado anteriormente naquele departamento da Polícia Militar. Lembra-se nitidamente que a delegada Magali Leite Cordeiro Pascoal teria proferido a seguinte frase quando ele e outros réus foram levados para a PHAC: "Taí os bugres para vocês! Tão meio sujos, mas são para vocês!". Ela assim o teria feito quando eles foram recepcionados por agentes carcerários que os receberam com hostilidade e lhes espancaram por vários dias. Recorda-se ainda que na PHAC ele e outros réus foram visitados por um funcionário da FUNAI, embora não tivessem tido a possibilidade de lhe relatar os ocorridos, visto que foram pressionados a permanecer calados; do contrário seriam espancados novamente e com mais intensidade. $\mathrm{Na}$ ocasião, um agente carcerário permaneceu nas proximidades para ouvir a conversa mantida entre os réus e o funcionário da FUNAI. Na PHAC o acusado recebeu propositalmente algumas pisadas com muita força no dedão de seu pé direito, o qual estava inchado, inflamado e com pus e sangue coagulado. Apesar de tanta dor, não imaginava que naquela parte de seu pé estava alojado um projétil de arma de fogo, pois durante a ação não chegou a sentir muitas dores no local. Somente depois de dias naquele presídio é que os outros réus presos foram observar com mais atenção seu ferimento. Inicialmente pensaram tratar-se de algum tipo de "berne" (Dermatobia hominis) ou "bicho de pé" (Tunga penetrans), mas ao cortarem as primeiras camadas da pele de seu dedo com uma lâmina de barbear, constataram trata-se de um projétil de arma de fogo, por eles identificada como sendo de uma pistola. Este projétil foi extraído do dedão do pé direito do acusado e jogado fora antes da revista que os agentes carcerários periodicamente faziam nas celas a procura de drogas ilícitas, armas, aparelhos celulares etc.

Feita esta digressão, retoma-se aqui o assunto em pauta, qual seja, a presença dos três policiais civis na aldeia de Passo Piraju no dia $1 \%$ \%4/2006.

De acordo com as narrativas registradas, a presença dos policiais no interior da aldeia provocou medo e grande correria na comunidade. Naquele momento algumas pessoas se armaram com o que tinham à disposição. Assim o fizeram para proteger a comunidade e enfrentar os estranhos karai que se comportavam de forma belicosa, contrariando de maneira grotesca as regras sociais que estavam acostumados a seguir na vida tribal.

Pelo comportamento demonstrado pelos policiais, eles foram imediatamente confundidos com "jagunços" ou "pistoleiros" a serviço de fazendeiros da região ou de pessoas assim reconhecidas por eles. Muitos indígenas pensaram tratar-se de Beline Nascimento Chaves, filho de Esmalte Barbosa Chaves, e seus aliados, ou de pessoas a ele ligadas, que muitas vezes os perturbavam nos finais de semana com "bombas" (rojões e espécies de bombas caseiras de pólvora) e até mesmo com disparos de 
arma de fogo. Em meio a uma situação de alvoroço e pânico, os policiais se evadiram do interior da aldeia e seguiram de carro pela MS 156 em direção à ponte que existe sobre o rio Dourados, localizada há poucos metros dali, seguindo no rumo de quem vai para o município de Caarapó. Pouco tempo depois eles retornaram pela mesma rodovia. Quando voltavam em direção à cidade de Dourados, Ezequiel Valensuela e Paulino Lopes teriam feito sinal para eles pararem com o intuito de saber o motivo dos tiros disparados no interior da aldeia. Assim que o automóvel parou, um dos policiais teria disparado uma arma de fogo para amedrontá-los. Foi então que a luta teve início e alguns indígenas revidaram contra os policiais, que ocupavam o interior da perua Parati. Agiram desta forma para impedir que eles pudessem vir a retornar ao interior da aldeia, pela entrada principal, e revidaram contra o que entenderam ser uma nítida tentativa de Ihes causar mal. Neste momento, os três policiais foram atacados e disto decorreu a morte de dois deles e ferimentos causados a um terceiro, que poderia ter ido a óbito na ocasião.

Figura 7: Imagem de satélite da região de Porto Cambira obtida do Google Earth em 24/05/2008, com a indicação da área da aldeia de Passo Piraju. As setas indicam pontos onde havia habitações indígenas.

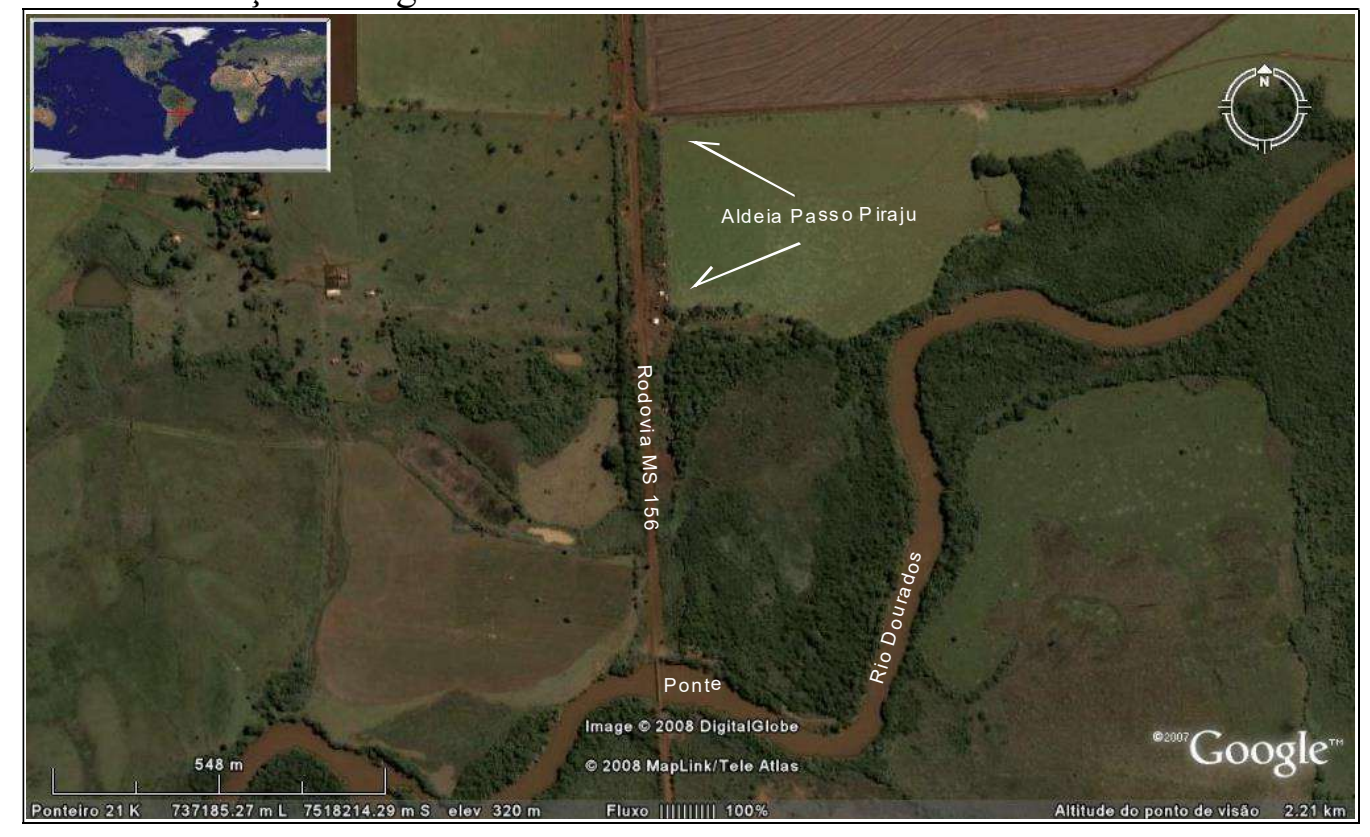

No que diz respeito aos termos "jagunço" e "pistoleiro" (pronunciado em guarani como pitolero), utilizados pelos réus e por muitas outras pessoas da comunidade de Passo Piraju, tratam-se de palavras frequentemente recorridas para se referir a homens armados contratados por fazendeiros para fazer a segurança de suas propriedades ou por outras pessoas assim percebidas pelos indígenas. O termo "polícia de fazendeiro" também é comumente empregado com o mesmo significado.

Figura 8: Imagem de satélite obtida do Google Earth em 24/05/2008, com a indicação dos seguintes pontos: $\mathbf{A}=$ local por onde os policiais teriam entrado e saído da área da aldeia; $\mathbf{B}=$ habitações indígenas; $\mathbf{C}=$ margem da rodovia MS 156 onde famílias indígenas 
estavam estabelecidas até 2004 e onde havia algumas plantas rasteiras cultivadas, como a batata-doce (Ipomoea batatas); $\mathbf{D}=$ principal estrada que dá acesso ao interior da aldeia; $\mathbf{E}=$ local do confronto contra os policiais.

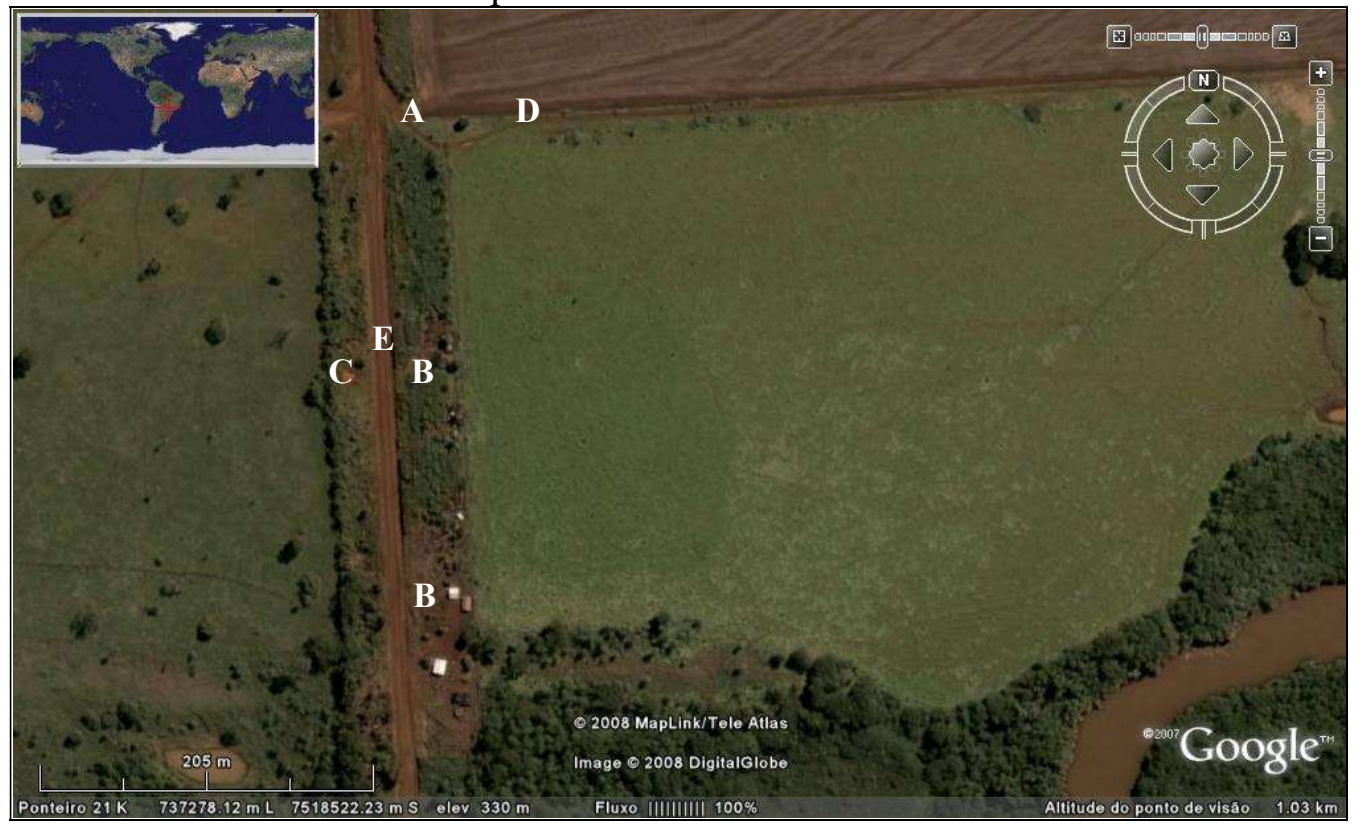

De acordo com o entendimento dos réus e da comunidade de Passo Piraju, os indígenas não "fizeram tocaia, rendendo as vítimas após emboscada adredemente planejada", conforme consta na denúncia ofertada pelo Ministério Público Federal à Justiça Federal, folhas 2-23 dos Autos. Alguns dos réus e outros membros do grupo foram rapidamente ao encontro dos policiais e agiram com agressividade de acordo com um comportamento coletivo comum em situações desse tipo. A violência praticada contra os estranhos armados foi uma espécie de reciprocidade negativa, isto é, uma agressão coletiva praticada contra aqueles karai desconhecidos que se comportaram de forma semelhante a "jagunços" ou "pistoleiros", quer dizer, da mesma forma que os não-índios armados que anteriormente agiram com belicosidade contra eles. Significa dizer que a ação dos policiais foi interpretada como uma ofensa e uma verdadeira declaração de guerra a todos os membros da comunidade indígena. Esta situação foi ainda agravada pelo fato de o episódio ter ocorrido em um sábado à tarde. Isto porque era nos finais de semana que essas pessoas trafegavam pela região e os atacavam e amedrontavam com rojões, tiros com armas de fogo e manobras bruscas com camionetes e carros menores. O cidadão Belino Nascimento Chaves, filho de Esmalte Barbosa Chaves, juntamente com alguns aliados desconhecidos pelos indígenas, foi apontado como o principal perturbador da ordem tribal. Dessa forma, os indivíduos que participaram diretamente da agressão perpetrada contra os três agentes policiais agiram segundo os princípios de solidariedade e responsabilidade coletiva que caracterizam o direito indígena entre os Guarani e Kaiowa. 
Belino Nascimento Chaves é apontado por lideranças da comunidade como o responsável pelo atropelamento de um indígena idoso chamado Sérgio Araújo, ocorrido em 2005. O acidente aconteceu quando a vítima trafegava de bicicleta pela rodovia MS 156 e teria sido propositalmente escolhida pela camionete dirigida pelo citado cidadão não-indígena. Paradoxalmente, depois do ocorrido o próprio motorista teria levado a vítima, que estava quase que inconsciente, em seu carro para a comunidade de Passo Piraju. Ele assim teria feito, explicaram os índios, para demonstrar que havia prestado ajuda a alguém que teria sido atropelado por outra pessoa. Este comportamento reprovável é chamado em guarani de ñẽbotavy, isto é, de fazer-se de tonto, bobo, inocente ou desinformado para enganar ou ludibriar terceiros. O fato é que Sérgio Araújo teria reconhecido o motorista que dirigia o veículo que o atropelou e narrou o acontecido a alguns de seus pares. As informações sobre este fato vão ao encontro de parte do conteúdo do Relatório de visita ao Hospital Evangélico de Dourados, produzido pelo antropólogo Marcos Homero Ferreira Lima no dia 17/06/2005 e encaminhado a seus superiores no Ministério Público Federal em Dourados. Segundo consta no relatório, o atropelamento ocorreu no início da noite do dia $16 / 06 / 2005$, pouco menos de um ano antes da agressão sofrida pelos policiais civis. Por sua relevância, uma cópia do documento segue em anexo ao presente laudo pericial.

Durante as conversas mantidas com os réus presentes na comunidade de Passo Piraju, todos eles, sem exceção alguma, demonstraram consternação, tristeza e lamentaram o acontecido contra os policiais civis. Perguntados - em português - se estavam arrependidos, em um primeiro momento disseram de maneira confusa que não, pois entenderam o termo "arrependimento" como sinônimo de sentir medo e não como atitude contrária ou oposta àquela tomada anteriormente. Refeito o questionamento no idioma guarani, eles usaram a expressão rembyasy para externar o fato de estarem intensa e dolorosamente tristes e de se sentirem mal pelo acontecido e seus desdobramentos. Contudo, manifestaram abertamente temer futuras retaliações por parte de policiais militares e civis.

Os réus, em especial o indígena Carlito de Oliveira, apontaram a SEPRIVA Segurança Ltda. como tendo sido a empresa contratada por fazendeiros locais para defender a Fazenda Campo Belo contra a "invasão" ou a "retomada" daquelas terras por parte dos indígenas ${ }^{16}$. Antes do acontecido, diversas vezes seguranças da empresa teriam disparado armas de fogo e jogado pequenas "bombas" (rojões e outros tipos de explosivos) em direção às residências dos moradores da aldeia, geralmente no final da tarde ou à noite, com o objetivo de lhes causar medo e fazê-los sair do lugar. E como dito amiúde, o próprio filho de Esmalte Barbosa Chaves, Beline Nascimento Chaves, teria agido da mesma

\footnotetext{
${ }^{16}$ Segundo apurado, o referido produtor rural não teve qualquer participação no processo de esbulho que os índios afirmam ter havido naquela região entre as décadas de 1940 e 1950.
} 
Espaço Ameríndio

forma e com certa frequência dias antes ao tempo da ação, sobretudo nos finais de semana17.

Consta na Internet que a referida empresa está localizada à Rua Félix de Albuquerque n. 29, bairro Ana Maria Couto, na cidade de Campo Grande. Atende pelo telefone (67) 99217-4973 e pelo endereço eletrônico wagnergoncalvesmiranda@hotmail.com. Seguem informações divulgadas sobre seus trabalhos na Internet:

Esta no mercado a dez anos e hoje trabalha em posto fixo com vigilancia armada e em eventos dentro de Campo Grande, Miranda, Jardin, Aquidauana, Anastácio, Três Lagoas, Corumbá, Dourados, Fátima do Sul e Ponta Pora $^{18}$. (transcrição ipsis litteris)

No dia 09/02/2004, às 13 h31 min., o jornal eletrônico Midiamax News publicou a matéria Fazendeiro contrata segurança para se proteger de índios, assinada por Thaísa Bueno, em que informou que Esmalte Barbosa Chaves estaria a contratar uma empresa de segurança para proteger sua propriedade contra a "invasão" dos indígenas:

Uma empresa de segurança, que ainda não teve o nome divulgado, vai se instalar esta noite na fazenda Campo Belo, em Dourados, invadida hoje por cerca de 200 índios, para garantir a segurança da família dos proprietários e também dos trabalhadores.

Conforme o produtor Esmalte Barbosa Chaves, a partir desta noite e até que seja feita a reintegração de posse da área, os seguranças particulares vão cercar a sede da propriedade.

"Estou contratando os seguranças porque essa terra é tudo que tenho. Se os índios tomarem a sede não tenho onde trabalhar", justifica, lembrando que tomou a atitude por orientação do Sindicato Rural da cidade.

O proprietário entra esta tarde na Justiça pedindo a reintegração de posse da terra, tomada por aproximadamente 200 índios guarani-caiuiá, que há cinco anos viviam desaldeados num acampamento próximo a rodovia da fazenda ${ }^{19}$.

Dias depois, no mesmo mês de fevereiro de 2004, o mesmo jornal eletrônico divulgou a matéria Índios desocuparam fazenda Campo Belo, afirma PF, assinada por Silvia Frias, na qual consta o seguinte:

\footnotetext{
${ }^{17}$ Um outro não-índio, identificado como "Avelino", seria mais um produtor rural que teria agido com agressividade contra a comunidade de Passo Piraju antes do tempo da ação.

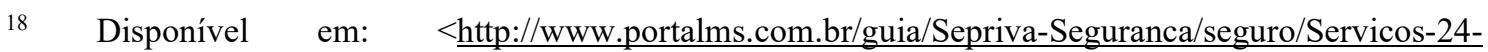
horas/Campo-Grande/5/911.html>. Acesso em: 24 mai. 2008.

19 BUENO, Thaísa. 2004. Fazendeiro contrata segurança para se proteger de índios. Disponível em: $<$ http://www.midiamax.com/view.php?mat_id=83823\#>. Acesso em: 03 jun. 2008.
} 
Os índios guarani-caiuás que ocupavam a Fazenda Campo Belo já teriam saído da área ontem, no fim da tarde, e hoje estariam terminando de desmontar os barracos de lona. O delegado da Polícia Federal de Dourados, Lázaro Moreira disse que no período da tarde uma equipe vai acompanhar o oficial de justiça para constatação e efetivar a reintegração de posse. No dia 8, cerca de 100 índios ocuparam a fazenda de mil hectares, localizada em Porto Coimbra, distante 30 quilômetros de Dourados.

O grupo é formado por guaranis desaldeados que estavam acampados há cinco anos às margens da rodovia e resolveram reivindicar a área, embora não exista comprovação por laudo antropológico que ateste a propriedade da terra. O produtor Esmalte Barbosa Chaves, dono da fazenda, entrou com mandado de reintegração de posse, pedido deferido pela juíza federal Luciana Bezerra.

Ontem, o administrador regional da Funai (Fundação Nacional do Índio) de Dourados, Israel Bernardo negociou a saída pacífica, antes que a PF cumprisse a determinação mediante uso da força. Os índios exigiram alimentos e medicamentos para deixar a área e Bernardo somente pode sair da fazenda após assinar o acordo. Lázaro Moreira disse que os guarani-caiuás deixaram a área ontem mesmo e hoje terminariam de retirar os barracos ${ }^{20}$.

As informações até aqui apresentadas atestam, de modo insofismável, que a região de Porto Cambira, onde está situada a aldeia de Passo Piraju, tem sido, desde antes dos acontecimentos, principalmente a partir de 2004 e até o presente momento, uma área de intensos conflitos interétnicos relacionados à disputa pela terra entre indígenas e produtores rurais.

No que diz respeito aos réus Jair Aquino Fernandes, Valmir Junior Savala e Sandra Arevalo Savala, constatou-se, com efeito, que eles foram os primeiros acusados presos pela ROTAI (Ronda Ostensiva Tática do Interior), grupo de elite da Polícia Militar do estado de Mato Grosso do Sul, na noite do dia dos acontecimentos. Inicialmente foram levados para a Delegacia do Primeiro Distrito Policial de Dourados, onde haviam muitas pessoas indignadas com o acontecido e que demonstravam querer vingar os policiais agredidos. Por medida de segurança foram levados na noite da mesma data para a sede do DOF nesta cidade. Ali tiveram início os interrogatórios sob a presença da delegada Magali Leite Cordeiro Pascoal.

Os três acusados explicaram que na ocasião a delegada da Polícia Civil estava bastante nervosa, os chamou de "bugres" e repetidas vezes os acusou de terem matado os policiais. Também

\footnotetext{
20 FRIAS, Silvia. 2004. Índios desocuparam fazenda Campo Belo, afirma PF. Disponível em: $<$ http://www.midiamax.com/view.php?mat_id=86023 > . Acesso em: 03 jun. 2008.
} 
disseram que foram espancados por policiais militares do DOF, que os forçou a confessarem sua própria culpabilidade na ação. De acordo com as narrativas proferidas pelos indígenas, os policiais militares os espancaram e disseram a eles que os mesmos seriam mortos caso viessem a denunciá-los posteriormente. Jair Aquino Fernandes relatou que foi espancado até desmaiar. Valmir Junior Savala e Sandra Arevalo Savala - a ré cuja história foi descrita anteriormente também receberam socos, pontapés e pancadas com cacete, sobretudo na cabeça e no estômago. Tudo aconteceu durante aproximadamente 24 horas, a partir da noite de sábado, dia $1^{\circ}$ de abril de 2006, com breves interrupções. Os três réus também afirmaram explicitamente que foram torturados por meio de sessões de choque elétrico no pescoço e nas orelhas. Segundo suas narrativas, isso foi feito por meio de um aparelho de eletrochoque que produzia eletricidade através de uma espécie de dínamo acionado manualmente por uma manivela ou algo parecido que girava em sentido horário. $O$ aparelho tinha dois fios elétricos, os quais eram presos ora em suas orelhas, ora em seus pescoços. Por esses fios passava uma corrente elétrica que percorria seus corpos, causandoIhes intensa dor. Durante essas sessões eles permaneceram algemados em um tipo "tronco" existente em um "barracão" construído nos fundos da sede do DOF em Dourados.

As sessões de torturas com eletrochoque foram descritas com clareza e detalhes surpreendentes diante dos peritos do Juízo e da assistente técnica do Ministério Público Federal. Até então os três réus disseram desconhecer completamente a existência de um aparelho desse tipo e da prática de sessões de eletrochoque para a tomada de depoimentos. Um policial chamado "Betão" teria sido o servidor público que recebeu a ordem da delegada Magali Leite Cordeiro Pascoal para operar a máquina de eletrochoque ${ }^{21}$.

Portanto, de acordo com as narrativas desses três indígenas, foi desta forma que eles, após serem presos no dia 1\%/04/2006, tiveram de assinar as confissões que constam nos Autos. Os mesmos afirmaram que o próprio escrivão responsável por lavrar os depoimentos também os ameaçou de morte caso não assinassem suas próprias confissões e, dessa forma, assumissem a culpabilidade dos crimes. O mesmo foi dito sobre uma policial que falava o idioma guarani do Paraguai e que os interrogou de maneira obtusa: não lhes fazia perguntas a respeito de sua eventual participação na ação contra as vítimas, mas exigia de maneira incisiva que eles contassem os detalhes de como teriam agido contra os policiais civis, e ordenava que afirmassem que Carlito de Oliveira teria sido o mandante da suposta "tocaia".

$\mathrm{Na}$ manhã de domingo, dia 02/04/2006, outros três indígenas (Lindomar Brites de Oliveira, Marcio da Silva Lins e Paulino Lopes) foram presos e igualmente encaminhados para a tomada de depoimentos.

\footnotetext{
${ }^{21}$ Conforme é amplamente conhecido no mundo jurídico e na academia, máquinas de eletrochoque criadas inicialmente na década de 1930 para fins de tratamento psiquiátrico - foram utilizadas por forças policiais e militares no período de arbítrio que vigorou durante o regime militar (1964-1985).
} 
Segundo afirmaram, quase todos eles também receberam o mesmo tratamento degradante dispensado aos três primeiros indígenas presos. Apenas Marcio da Silva Lins disse não ter recebido sessões de eletrochoque. No caso de Lindomar Brites de Oliveira, o réu teria sido torturado por mais tempo por ser filho de Carlito de Oliveira, quem até então não havia sido encontrado por forças policiais.

$\mathrm{Na}$ quarta-feira, dia 04/04/2006, policiais detiveram o indígena Hermínio Romero, mais conhecido na comunidade de Passo Piraju como "Roberto Farinha" ou simplesmente "Farinha". Vários membros da comunidade, como a indígena Ramona Savala, esposa do referido réu, explicaram que ele foi agredido na ocasião de sua prisão, tendo recebido pancadas na cabeça, no pescoço e em outras partes do corpo. Uma dessas pancadas causou um ferimento na cabeça, atestado como lesão corporal leve nos Autos, folhas 239-240. Em um relatório da Polícia Civil, anexado nos Autos (folhas 134 e 135), consta que inicialmente o acusado não teria atendido à voz de prisão que Ihe foi dada por policiais às margens do rio Dourados. Saiu em disparada, foi perseguido e acabou sendo detido ali mesmo. Sobre o ferimento em sua cabeça, assim consta no documento:

Informo ainda que segundo HERMÍNIO, o ferimento que possui em sua cabeça é proveniente de um acidente ocorrido quando "furava um poço", oportunidade que o balde utilizado para retirar a terra cavada caiu sobre sua cabeça provocando a lesão.

Este é mais um exemplo do quanto há de contradições entre os documentos produzidos pela Polícia Civil e a versão dos fatos apresentada por indígenas da comunidade de Passo Piraju. Para os indígenas a sociedade nacional e o Estado brasileiro, incluindo o sistema judiciário, valorizam o "papel", chamado em guarani de kuatia, isto é, o documento oficial, em detrimento de desprezar a narrativa dos indivíduos. Dito de outra maneira, se a sociedade nacional dá mais valor ao que está registrado no papel (tradição escrita), os Guarani e Kaiowa dão mais valor ao que está registrado na memória das pessoas e de suas comunidades (tradição oral).

No dia anterior, 03/04/2006, o indígena Antônio da Silva, esposo de Teodocia Savala, desapareceu quando pescava no rio Dourados. Seu desaparecimento é tido entre a comunidade indígena como sendo morte causada por policiais que ali estiveram naquela data ou por outras pessoas que se fizeram passar como tais na mesma ocasião.

$\mathrm{Na}$ mesma semana, dia 06/04/2006, foram presos Carlito de Oliveira e Ezequiel Valensuela, os quais foram interrogados pela delegada Magali Leite Cordeiro Pascoal. A tomada de seus depoimentos foi testemunhada pela professora Valdelice Veron, indígena da etnia Kaiowa que coordena a Escola Municipal Pa'i Chiquito, localizada na aldeia Panambizinho, distrito Panambi, município de Dourados. Ela é filha de Marcos Veron, líder indígena assassinado na madrugada do dia 13/01/2003, na Fazenda Brasília do Sul (Aldeia Takuara), município sulmato-grossense de Juti, e fez parte de um grupo de lideranças indígenas 
que apoiou a comunidade de Passo Piraju naqueles momentos e posteriormente.

Depois de concluídos os depoimentos, os seis primeiros réus presos foram transferidos para a sede da Polícia Federal na cidade de Dourados. Lá permaneceram de segunda à quarta-feira e não disseram ter sofrido violência física por parte de quaisquer policiais. Entretanto, disseram que em uma noite um policial federal de estatura alta, cor da pel branca e cabelos loiros ou castanhos claros, de aparência do tipo "alemão", colocou grande quantidade de sal fino por cima da comida que eles receberam em uma embalagem descartável do tipo "marmitex". Depois de terem ingerido muito sal ficaram com sede, mas sem água para beber. Este policial os chamava de "monstros".

O réu Carlito de Oliveira explicou que quando foi levado para a Polícia Federal, o mesmo policial "loiro" ou "alemão" ameaçou degolar seu pescoço e pendurar sua cabeça em um pau. Este servidor federal ainda arrancou um colar que o líder indígena usava pendurado no pescoço e desferiu-lhe um soco na parte de trás de sua cabeça, desmaiando-o com a força do impacto da pancada. Aquele seria um colar de grande valor simbólico (religioso) para o acusado.

Conforme ainda narrativas uníssonas que fazem parte da memória dos acusados, quando os seis primeiros réus detidos foram transferidos para a PHAC, naquele mesmo estabelecimento penal foram duramente espancados por agentes carcerários, ficaram sem água para beber durante alguns dias e enfrentaram muito frio pela ausência de cobertor. Durante dois dias permaneceram em uma "cela forte" recebendo este tipo de tratamento. Um desses agentes carcerários era branco, forte, usava barba e tinha os cabelos de cor preta, conhecido pelos réus como "Lima", "Lins" ou "Seu Lino". Alguns presidiários responsáveis pela limpeza dos corredores do estabelecimento penal lhes deram, às escondidas, água para beber. Por vezes a única água possível de beber era a que esses detentos conseguiam puxar com o rodo para dentro da cela onde estavam presos, por debaixo da porta.

Ezequiel Valensuela, Lindomar Brites de Oliveira e Paulino Lopes afirmaram que o referido agente carcerário os marcou com tatuagens ou dermopigmentações feitas com um instrumento tosco e sem ser esterilizado, conforme consta na resposta apresentada ao quesito de $\mathrm{n}^{\circ}$. 5.1 , formulado pelo assistente de acusação.

Carlito de Oliveira e Ezequiel Valensuela também disseram que foram igualmente espancados na PHAC, porém não na "cela forte" e sim na "cela 66". Afirmaram que receberam pancadas com uma espécie de "mangueira" e que teriam ficado dias sem alimentação e dormindo no chão, onde passaram muito frio por não ter nenhum cobertor para se agasalhar.

Somente quando todos os réus do sexo masculino foram transferidos para a Penitenciária de Jateí é que passaram a ser tratados com mais dignidade e respeito, não recebendo sessões de espancamento, passando frio ou sendo privados de água e comida.

Tudo indica que os réus foram recebidos como "heróis" ou algo parecido no Presídio de Jateí. A recepção foi dada por alguns detentos 
não-índios que ali cumpriam pena e que teriam se sentido vingados ou justiçados com a morte de um dos dois policiais assassinados. Tratar-seia de alguém que em vida e no exercício de sua profissão teria abusado da autoridade policial e espancado com crueldade alguns apenados que ali cumpriam sentença. A descrição por eles feita vai ao encontro das características físicas do policial Rodrigo Pereira Lorenzatto.

Entrementes, o fato é que os réus até então nunca imaginaram que instituições policiais e a penitenciária de segurança máxima de Dourados fossem do jeito que testemunharam, pois nunca haviam sido tratados com tamanha violência. Esta mesma violência, apontada de maneira cristalina, peremptória e uníssona, é por eles entendida como uma punição muitíssima dolorosa e previamente sentenciada e aplicada pelos crimes de que são acusados.

Até hoje em dia muitos dos réus reclamam que sentem fortes dores na cabeça por conta dos choques elétricos e das pancadas que afirmam ter recebido após a ação perpetrada contra os policiais civis.

Esta explicação geral dos acontecimentos descritos pelos réus e por outros membros da comunidade de Passo Piraju também é tratada na resposta apresentada a outros quesitos formulados pelas partes. São acontecimentos que fazem parte da memória individual e coletiva, socialmente construída a partir de um evento histórico marcante na história da comunidade de Passo Piraju e transmitida por uma coletividade indígena através de sua tradição oral.

\subsection{OS RÉUS ERAM, AO TEMPO DA AÇÃO, ABSOLUTAMENTE INCAPAZES DE ENTENDER O CARÁTER ILÍCITO DE SUAS CONDUTAS?}

Não. A explicação para esta negativa consta na resposta apresentada ao quesito anterior, o de $n^{\circ}$. 2.3.

2.4. DEVEM OS PERITOS ESCLARECER SE OS RÉUS, DE ETNIA INDÍGENA, ESTAVAM DEVIDAMENTE INTEGRADOS À CULTURA DA SOCIEDADE DOS NÃO-ÍNDIOS, NO SENTIDO DE ENTENDEREM O CARÁTER ILÍCITO DA CONDUTA POR ELES PERPETRADA, NOS TERMOS DO ART. $4^{\circ}$, III C/C 56, AMBOS DA LEI No. 6.001/73?

Não. A resposta formulada ao quesito de $\mathrm{n}^{\circ}$. 2.2, também apresentado pelo Juízo, serve para compreender melhor esta resposta negativa.

No Brasil os indígenas estão sujeitos a um regime especial inicialmente regulamentado pelo Decreto $n^{\circ}$. 5.484 , de $27 / 06 / 1928$, cujo espírito colonialista acompanhou a lógica da política indigenista oficial de caráter assimilacionista. Esta lógica foi definitivamente superada com a Lei Maior de 1988, apropriadamente chamada de Constituição Cidadã. Esta lei é um verdadeiro divisor de águas para o direito indigenista, pois reconhece a diversidade étnico-cultural existente no país e, mais, assegura direitos para minorias étnicas como às indígenas e quilombolas.

No caso do Decreto $n^{\circ}$. 5.484, trata-se de uma lei em que os indígenas ou "silvícolas" - termo positivista pelo qual são chamados na 
legislação antiga - passaram a ser distinguidos entre nômades, aldeados e civilizados. Na época os legisladores foram fortemente influenciados pela teoria da aculturação e assimilação dos índios à sociedade nacional. Esta teoria não esteve em voga apenas no mundo jurídico, mas também nas ciências sociais em geral, como na própria antropologia, e sua origem remonta a práticas colonialistas. O paradigma em vigor baseava-se na máxima de que inevitavelmente os índios desapareceriam enquanto grupos étnicos diferenciados, isto é, que gradualmente perderiam sua cultura (usos, costumes, língua, religião, organização social, cosmovisão, regras sociais etc.) e se tornariam "civilizados" e plenamente incorporados à comunhão nacional.

O mesmo espírito assimilacionista inspirou a elaboração do Estatuto do Índio de 1973 (Lei n. 6.001/1973), uma lei criada durante o regime militar implantado com o golpe de Estado de 1964 e que se apresenta como anacrônica e defasada se comparada à atual Carta Constitucional, de 05/10/1988, à Convenção OIT $n^{\circ}$. 169, de 07/06/1989, e à Declaração Universal dos Direitos dos Povos Indígenas, aprovada pela ONU em 13/09/2007.

No caso específico da Convenção da OIT (Organização Internacional do Trabalho) $n^{\circ}$. 169, sabe-se que o Brasil não é um mero signatário deste instrumento internacional. Referendou-o por meio do Decreto Legislativo $n^{\circ}$. 143, de 20/06/2002, assinado pelo senador Ramez Tebet, professor de direito e renomado parlamentar peemedebista pelo estado de Mato Grosso do Sul, falecido em 2006, que na época respondia pela Presidência do Senado Federal.

Apesar disso tudo, o Artigo $4^{\circ}$ do Estatuto do Índio de 1973 diz o seguinte:

Art. $4^{\circ}$ Os índios são considerados:

I - Isolados - Quando vivem em grupos desconhecidos ou de que se possuem poucos e vagos informes através de contatos eventuais com elementos da comunhão nacional;

II - Em vias de integração - Quando, em contato intermitente ou permanente com grupos estranhos, conservem menor ou maior parte das condições de sua vida nativa, mas aceitam algumas práticas e modos de existência comuns aos demais setores da comunhão nacional, da qual vão necessitando cada vez mais para o próprio sustento; e

III - Integrados - Quando incorporados à comunhão nacional e reconhecidos no pleno exercício dos direitos civis, ainda que conservem usos, costumes e tradições característicos da sua cultura (MAGALHÃES, 2003, p.49).

De um ponto de vista antropológico não há dúvida alguma de que todos os réus mantêm frequentes contatos com a sociedade nacional, mas definitivamente não estão integrados à comunhão nacional por vários motivos. Um deles diz respeito ao fato de eles ainda não poderem exercer a plena cidadania. Isto ocorre por causa da ineficiência dos 
poderes constituídos na República em assegurar o respeito e o cumprimento de seus direitos. Outrossim, também é certo que os acusados conservam parte significativa de seu modo de vida tradicional, quer dizer, de um modus vivendi culturalmente dinâmico ao qual atribuem o sentido de tradicional.

Por isso torna-se imperativo registrar que o conceito de "tradicional" a que inclusive se refere o Artigo $231, \S 1^{\circ}$, da Constituição Federal, tem a ver com aquilo que os indígenas dão sentido de tradicional e não necessariamente àquilo que os não-índios (antropólogos, historiadores, jornalistas, operadores do direito etc.) possam imaginar ou avaliar ser tradicional ou típico nas culturas indígenas.

Sem embargo às explicações apresentadas, também é fato que os indígenas têm incorporado ou aceitado "algumas práticas e modos de existência comuns aos demais setores da comunhão nacional, da qual vão necessitando cada vez mais para o próprio sustento". Isto é visível, por exemplo, no que se refere à cultura material (máquinas e equipamentos diversos, ferramentas de trabalho etc.), ao acesso à saúde pública e à própria subsistência. Entretanto, esta questão é mais complexa do que pode parecer à primeira vista porque os contatos interétnicos e as trocas culturais são uma via de mão dupla, de mútuas influências. Isto não significa que os indígenas deixarão de ser o que são, isto é, que perderão sua distintividade étnica, ou que os não-índios se tornarão culturalmente iguais a eles. Ademais, os elementos da cultura nacional quando incorporados pelos grupos indígenas sofrem um contínuo processo de ressignificação, de transformação e adaptação a uma lógica cultural específica. Por este processo endógeno os elementos culturais exógenos passam a ter sentido de tradicional entre os indígenas, visto que eles próprios assumiram o papel de principais atores sociais, sujeitos históricos e protagonistas de sua história.

Um dos maiores exemplos disso são as influências do pentecostalismo moderno na Reserva Indígena de Dourados, onde alguns acusados nasceram, o qual tem sido ressignificado a ponto de dar origem a pentecostalismo indígena ${ }^{22}$. Sobre este assunto, o antropólogo sulmato-grossense Levi Marques Pereira, docente e pesquisador da UFGD, perito da Justiça Estadual e da Justiça Federal, produziu um importante estudo intitulado $O$ pentecostalismo Kaiowa: uma aproximação dos aspectos sociocosmológicos e históricos. Neste trabalho, cujo assunto não será aqui esmiuçado, o reconhecido etnólogo analisou "como os processos de transformação no ambiente e na sociedade Kaiowa se expressam a partir da oposição de categorias como as de jovem e antigo e de crente e não-crente" (PEREIRA, 2004, p.267).

Portanto, "os réus, de etnia indígena”, não "estavam devidamente integrados à cultura da sociedade dos não-índios, no sentido de entenderem o caráter ilícito da conduta por eles

\footnotetext{
22 Segundo consta na enciclopédia Wikipédia: "Pentecostalismo é como se chama a doutrina de determinados grupos religiosos cristãos, originários no seio do protestantismo, que se baseia na crença do poder do Espírito Santo na vida do crente após o Batismo do Espírito Santo, através dos Dons do Espírito Santo, começando com o dom de línguas (glossolalia)" (Wikipédia - A Enciclopédia Livre. Disponível em:

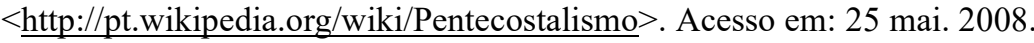


perpetrada, nos termos do art. $4^{\circ}$, III c/c 56, ambos da Lei $\mathrm{n}^{\circ}$. 6.001/73". Estavam, por assim dizer e em atenção estrita ao Estatuto do Índio em vigor, "em vias de integração”, o que não significa, bem entendido, que daqui algum tempo estarão integrados à comunhão nacional.

Todo modo, conforme determina o Artigo 56 do referido Estatuto do Índio, no caso de os acusados serem condenados "por infração penal, a pena deverá ser atenuada e na sua aplicação o juiz atenderá também ao grau de integração do silvícola". Com efeito, o Parágrafo Único deste artigo estabelece o seguinte:

As penas de reclusão e de detenção serão cumpridas, se possível, em regime especial de semiliberdade, no local de funcionamento do órgão federal de assistência aos índios mais próximo da habitação do condenado (MAGALHÃES, 2003, p.59).

No caso de condenação dos réus e em atenção a este dispositivo legal, o magistrado deve levar em conta que o confinamento deles na PHAC poderá levá-los a cometer suicídio, visto a experiência dolorosa enfrentada naquele estabelecimento penal. No Presídio de Jateí, por outro lado, quiçá pudessem não se sentir tão violentados quanto afirmam ter sido em Dourados.

Em face do elevado número de índios confinados em penitenciárias existentes no estado, estimado em 107 indivíduos no ano de 2007, a maior população indígena carcerária do país (a grande maioria sem a devida assistência jurídica por parte da FUNAI), seria prudente e oportuno haver uma penitenciária exclusiva para acomodar este contingente populacional ${ }^{23}$.

Não obstante, o Artigo 10 da Convenção OIT $n^{\circ} .169$ trata especificamente dos indígenas apenados:

1. Quando sanções penais sejam impostas pela legislação geral a membros dos povos mencionados, deverão ser levadas em conta as suas características econômicas, sociais e culturais.

2. Dever-se-á dar preferência a tipos de punição outros que o encarceramento.

Essas considerações levam em conta, também, os resultados do estudo intitulado Situação dos detentos indígenas no estado de Mato Grosso do Sul, coordenado por Carlos Macedo e Andréa Flores (2008), publicado muito recentemente. Este estudo é o resultado de uma

\footnotetext{
${ }^{23}$ Vide matérias: (A) Representante da OAB-MS critica segregação de índios em penitenciárias. Divulgada em 09/05/2008 no sítio eletrônico da OAB Mato Grosso do Sul. Disponível em: $<$ http://www.oabms.org.br/noticias/lernoticia.php?noti_id=4541>. Acesso em: 27 mai. 2008. (B) NAVARRO, Cristiano. 2007. Ministério da Justiça mostra primeiros dados sobre indígenas presos. Disponível em: $<$ http://www.cimi.org.br/dev.php?system $=$ news\&action $=$ imprimir\&id=2700\&eid=235 $>$. Acesso em: 27 mai. 2008.
} 
minuciosa pesquisa feita com a população indígena carcerária do estado. Durante entrevistas que os pesquisadores fizeram com os índios apenados, a maioria demonstrou desconhecer "por completo a situação processual na qual estavam envolvidos e as próprias regras do sistema prisional" (MACEDO e FLORES, 2008, p.29). Mais ainda:

Um aspecto relevante do diagnóstico é a constatação da pouca garantia dos direitos nos julgamentos de ações criminais. Detectaram-se ainda o descumprimento das garantias individuais na fase de execução penal, solapando direitos assegurados na legislação brasileira em geral e na legislação indigenista e, ainda, por Convenções e Declarações de caráter internacional, verificando-se, com isso, a violação dos direitos humanos (MACEDO e FLORES, 2008, p.13).

Apesar disso tudo, em caso de condenação dos acusados, o ideal seria mantê-los preso na própria aldeia de Passo Piraju, ou em outra aldeia próxima. Isto porque, salvo melhor juízo, todos eles são indivíduos sem histórico de crimes anteriormente cometidos contra pessoas daquela comunidade ou da sociedade nacional.

3. Quesitos do Ministérios Público Federal - Procuradoria da República em Dourados

3.1. DE ACORDO COM O ARTIGO $4^{\circ}$ DA LEI 6.001/73, QUAL O GRAU DE INTEGRAÇÃO DOS SILVÍCOLAS À SOCIEDADE DOS BRANCOS? DESCREVER INDIVIDUALMENTE, BEM COMO QUAIS OS MOTIVOS QUE LEVAREM OS PERITOS A ESSE ENTENDIMENTO.

A resposta para esta pergunta consta nas respostas formuladas para os quesitos apresentados pelo Juízo, em especial nos de número 2.2, 2.3 e 2.4 .

Ao tempo da ação todos os réus (Carlito de Oliveira, Ezequiel Valensuela, Hermínio Romero, Jair Aquino Fernandes, Lindomar Brites de Oliveira, Marcio da Silva Lins, Paulino Lopes, Sandra Arevalo Savala e Valmir Junior Savala) estavam em vias de integração se considerado o que determina o Estatuto do Índio de 1973 (Lei n 6.001). Não obstante, deve-se ressaltar que a perspectiva assimilacionista, que influenciou legisladores da época, foi refutada pela Constituição Federal de 1988, pela Convenção OIT no. 169 e pela Declaração Universal dos Direitos dos Povos Indígenas. Também foi sepultada na antropologia mundial a partir das décadas de 1960 e 1970 (vide BARTH, 1998 [1969]; PACHECO DE OLIVEIRA, 1999). Como dito amiúde, o importante é ter clareza de que todos os réus, sem qualquer distinção, são oriundos de grupos indígenas que possuem uma organização social e uma cultura que os distinguem em relação à sociedade nacional e que norteiam suas ações e seu entendimento sobre o mundo, inclusive do ponto de vista do direito. Sem considerar 
este paradigma, correr-se-á o risco de sobrepor o etnocentrismo e o evolucionismo de matriz eurocêntrica, explícitos no Estatuto do Índio de 1973, ao relativismo cultural e à valorização das diferenças étnicas e da cidadania que marcam legislações superiores aprovadas mais recentemente.

\subsection{QUAL É O CONCEITO QUE OS RÉUS POSSUEM DA POLÍCIA? OS RÉUS A VÊEM COMO UM ÓRGÃO CONFIÁVEL?}

Ver resposta dada ao quesito de $\mathrm{n}^{\circ}$. 2.2 formulado pelo Juízo.

Em complementação ao que foi discorrido anteriormente, explicase que faz parte da memória social coletiva da comunidade de Passo Piraju uma traumática experiência com forças policiais do antigo estado de Mato Grosso. Isto ocorreu na primeira metade do século XX, entre as décadas de 1930 e 1940. Na época as famílias kaiowa que ali moravam foram expulsas de seu território quando a terra foi titulada a favor de um terceiro que ali estabeleceu sua fazenda. Essas forças policiais são conhecidas pelos indígenas como "Captura", um símbolo de força e repressão que incute respeito e pavor entre os mais antigos.

"Captura" tornou-se uma metáfora para qualquer força policial que atuava com firmeza naqueles tempos. Historicamente foi uma força policial estadual criada para combater os grupos de "bandidos" ou "bandoleiros" que havia no sul do antigo Mato Grosso, atual Mato Grosso do Sul. Um desses bandos, o qual não consta ter passado pela região de Porto Cambira, foi o de Silvino Jacques, quem por volta de 1935 e 1936 matou um membro da família de Alípio dos Santos.

Conforme consta em documentos da época analisados pelo renomado historiador Valmir Batista Corrêa (1995, p.168), este "episódio teve origem numa desavença entre Silvino e um genro de Alípio dos Santos, durante uma 'carreira' (corrida rústica de cavalos), sendo mortos também um primo de Silvino e um seu camarada". Apenas a título de informação, registra-se que da mesma família Santos descende o exgovernador do estado de Mato Grosso do Sul, José Orcírio Miranda dos Santos, cujo pai, Orcírio dos Santos, foi comandante de uma "Captura" em Bela Vista, cidade sul-mato-grossense que faz fronteira com o Paraguai (vide IBANHES, 1997).

Na memória social do grupo, a "Captura" teria chegado àquele lugar para levar os indígenas às aldeias oficiais criadas pelo militar indigenista Cândido Mariano da Silva Rondon, fundador do Serviço de Proteção ao Índio (SPI), atual FUNAI. Este militar chegou ao posto de marechal do exército brasileiro e é uma figura saudosa na memória da grande maioria dos povos indígenas que vivem em Mato Grosso do Sul. Os mais antigos lembram que aqueles que não queriam ir por bem, eram levados à força para as reservas indígenas. Isto ocorreu em total desconsideração às terras tradicionalmente ocupadas por várias comunidades Guarani e Kaiowa na região. Segundo os indígenas, na ocasião houve tiroteios para intimidar as famílias kaiowa que ali viviam pacificamente. Assim, a "Captura" reprimiu a resistência indígena e as pessoas saíram dali deixando para trás suas roças, casas, animais, cemitérios, etc. 
Apesar de esta experiência ter ocorrido há muito tempo, quando a maioria dos réus sequer era nascida, ela faz parte da memória social coletiva do grupo e tem sido transmitida de geração a geração por meio da tradição oral. Disto originou-se uma imagem pouco positiva das forças policiais.

Os peritos observaram ainda que os agentes do serviço de segurança contratados pelo produtor rural Esmalte Barbosa Chaves, muitos deles funcionários da SEPRIVA Segurança Ltda., são chamados de "polícia do fazendeiro", o que indica uma percepção pejorativa do termo. Por outro lado, os periciados são enfáticos em afirmar que a população atual de Passo Piraju não teve, antes da ação, problemas com a polícia em si, seja "por conta de crime ou qualquer outra coisa culposa", conforme tratado na resposta dada ao quesito de $n^{\circ} .2 .2$ formulado pelo Juízo.

\subsection{O DESENVOLVIMENTO PSICOLÓGICO DOS EXAMINADOS É COMPATÍVEL COM A IDADE E NÍVEL DE SOCIALIZAÇÃO?}

Sim. Embora este seja um quesito de natureza psicológica, de um ponto de vista antropológico não resta dúvida alguma que o "desenvolvimento psicológico dos examinados é compatível com a idade e nível de socialização", guardadas as devidas diferenças socioculturais em relação à sociedade envolvente.

\subsection{QUAL É O VÍNCULO DOS EXAMINADOS COM A TERRA CONHECIDA COMO PASSO PIRAJU?}

Todos os nove réus, sem exceção alguma, estão ligados a uma comunidade indígena que possui vínculos tradicionais com "a terra conhecida como Passo Piraju". Eles possuem sentimento de pertencimento àquela região, seja por terem nascido ali, seja pelas relações de parentesco e de aliança política que estabeleceram com pessoas originárias daquele território. Isto explica o porquê de alguns dos réus pertencerem às etnias Guarani e Ofaié, visto que no passado ali viviam basicamente famílias da etnia Kaiowa.

A genealogia de Carlito de Oliveira, principal liderança política da comunidade, exemplifica perfeitamente bem esta situação, conforme demonstrado no diagrama de parentesco a seguir, cujo significado dos símbolos nele apresentados consta no Quadro 1, localizado no Capítulo 1 deste laudo, Histórico dos trabalhos e procedimentos científicos. Cumpre explicar em tempo que o número colocado ao lado direito de cada símbolo (triângulos, círculos e quadrado) identifica os indivíduos descritos na sequência. 
Genealogia de Carlito de Oliveira

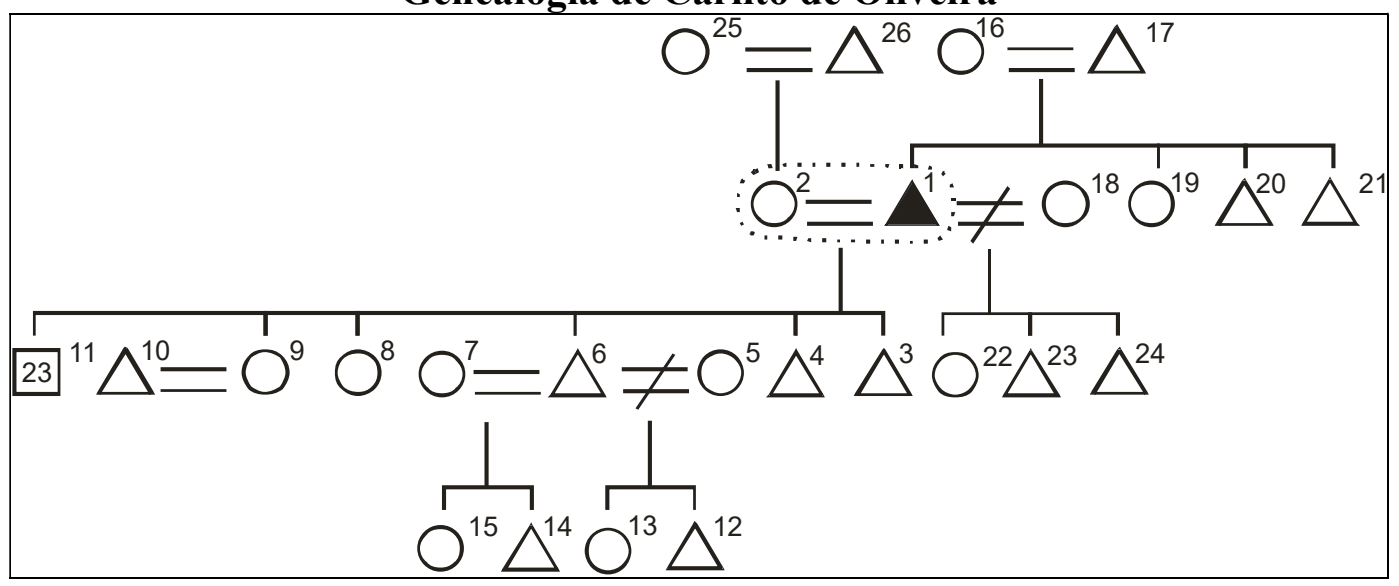

1 - Carlito de Oliveira, 67 anos, da etnia Kaiowa, nasceu em Passo Piraju e de lá foi expulso com sua família. Antes de retornar para seu local de nascimento, morou na Reserva Indígena de Dourados, onde sua família foi acomodada na década de 1940, depois de sofrer um processo de esbulho perpetrado contra os indígenas que viviam na região de Porto Cambira e adjacências. Seu casamento com Plácida Brites de Oliveira, da etnia Guarani, cuja conjugalidade está destacada no diagrama de parentesco, marca uma importante aliança interétnica entre famílias guarani e kaiowa.

2 - Plácida Brites de Oliveira, 43 anos, da etnia Guarani, nasceu na Reserva Indígena de Dourados, mas seus pais nasceram nas proximidades da região de Porto Cambira.

3 - Olímpio Brites de Oliveira, falecido quando tinha 6 meses de idade na aldeia Bororó, Reserva Indígena de Dourados.

4 - Itamar Brites de Oliveira, 10 anos, nasceu na aldeia Bororó e vive com seus pais em Passo Piraju.

5 - Valdíria Benites, primeira esposa de Lindomar Brites de Oliveira, com quem teve um casal de filhos.

6 - Lindomar Brites de Oliveira, 24 anos, filho de Carlito de Oliveira e Plácida Brites de Oliveira, nasceu na aldeia Bororó. Acompanhou seus pais desde os primeiros dias em que eles se estabeleceram na região de Porto Cambira. Como é filho de um Kaiowa e de uma Guarani, identifica-se mais como Guarani, embora às vezes se identifica como Kaiowa, sobretudo em situações nas quais é preciso diluir a distintividade étnica no meio tribal. 7 - Silmara de Souza, 19 anos, da etnia Kaiowa, nasceu na aldeia Te'ýi kue, em Caarapó, com quem Lindomar Brites de Oliveira está casado atualmente.

8 - Izabela Brites de Oliveira, falecida com um ano de idade na aldeia Bororó.

9 - Tainara Brites de Oliveira, 14 anos, nascida na aldeia Bororó e esposa de Valmir Junior Savala.

10 - Valmir Junior Savala, 20 anos, da etnia Kaiowa, nasceu na aldeia Te'ýi kue, filho de Rosalino Ramão Gonçalves (falecido) e Ramona Savala, de 63 anos, ambos de Passo Piraju. As famílias de seus pais tinham sido acomodadas na aldeia Guasuty, em Aral Moreira, quando da expulsão dos indígenas que viviam na região. Sua mãe, Ramona Savala, após ficar viúva 
casou-se com Hermínio Romero, 43 anos, também da etnia Kaiowa, nascido na aldeia Limão Verde, em Amambai, atualmente dado como desaparecido pela comunidade de Passo Piraju. Ramona Savala, por sua vez, é irmã de Teodocia Savala, esposa de Antônio da Silva, indígena também dado como desaparecido.

11 - Filhos adotivos (guácho), no total de 23 indivíduos, criados na aldeia Bororó, Reserva Indígena de Dourados. Alguns deles participaram da "retomada" de parte da terra que a comunidade Passo Piraju reivindica na região de Porto Cambira, mas com os desdobramentos da ação deixaram a área e seguiram outros destinos, a maioria de volta rumo à aldeia Bororó.

12 - Lindiomar Brites Benites, 6 anos, nascido na aldeia Bororó.

13 - Lindianara Brites Benites, 3 anos, nascida em Passo Piraju.

14 - Leonel Brites de Souza, 2 anos, nascido em Passo Piraju.

15 - Taiana Brites de Souza, 10 meses, nascida em Passo Piraju.

16 - Pedro de Oliveira, conhecido como "Pedro Caballero", nascido na região de Porto Cambira, em uma localidade chamada Laguna Hũ, falecido em Passo Piraju na década de 1950.

17 - Ramona de Oliveira, nascida em Passo Piraju e falecida na aldeia Bororó, na década de 1970.

18 - Celestina Vilhalva, nascida e residente na aldeia Bororó.

19 - Judite de Oliveira, moradora da aldeia Limão Verde, em Amambai.

20 - João de Oliveira, falecido na aldeia Bororó.

21 - Rogério de Oliveira, falecido na aldeia Bororó.

22 - Kuka de Oliveira, residente na aldeia Bororó.

23 - Ronildo de Oliveira, residente na aldeia Bororó.

24 - Ava Pijeguaka'i, residente na aldeia Bororó.

25 - Alcário Brites, da etnia Guarani, nascido em Passo Piraju e falecido em maio de 2008 na aldeia Bororó, quando tinha cerca de 100 anos de idade.

26 - Venância Benites, com cerca de 70 anos de idade, paralítica, mora em Passo Piraju e nascida nas proximidades da região de Porto Cambira.

Na genealogia de Carlito de Oliveira aparecem três outros réus: Lindomar Brites de Oliveira, Hermínio Romero e Valmir Junior Savala, todos participantes de uma rede de relações sociais com vínculos tradicionais com a região de Porto Cambira. Por este motivo é que em Passo Piraju muitas pessoas estão ligadas por laços de parentesco por consanguinidade (avós, pais, filhos, sobrinhos etc.) ou afinidade (cunhados, sogros, tios, guácho etc.).

Seguem informações genealógicas sobre os demais réus periciados, à exceção de Lindomar Brites de Oliveira, cujos dados principais constam na genealogia de Carlito de Oliveira, seu pai:

- Ezequiel Valensuela: 41 anos, da etnia Kaiowa, nascido na aldeia Téýi kue, em Caarapó, filho de Justina Zavala e Gene Valensuela, ambos falecidos em Te'ýi kue, porém nascidos em Passo Piraju, lugar de onde foram expulsos quando ainda eram crianças. Em Caarapó moram seus irmãos Luciano, Isidora e Lauriana. Sua mãe morreu quando tinha cerca de 10 anos de idade. A primeira esposa de Ezequiel já é falecida e deixou 
4 crianças (Lucas, 5 anos; Ivani, 9 anos; Mariele, 10 anos; e Caroline, 12 anos), algumas das quais criadas como guácho por Teodocia Savala. Atualmente está casado com Inácia Lopes, 32 anos, nascida na aldeia Te'ýi kue, com quem não tem filhos.

- Hermínio Romero, 43 anos, da etnia Kaiowa, nascido na aldeia Limão Verde, em Amambai, marido de Ramona Savala, 63 anos, quem por sua vez nasceu em Passo Piraju e é um de seus vínculos com a região de Porto Cambira. Encontra-se desaparecido.

- Jair Aquino Fernandes: 34 anos, da etnia Guarani, nasceu na aldeia Jaguapiru, Reserva Indígena de Dourados, e é filho de Rosalino Aquino, também conhecido como "Catalino Aquino", e Cambíria Fernandes. Seus avós maternos, Horácio Fernandes e Rosalina, nasceram em Passo Piraju, e foram os responsáveis pela sua criação desde quando era criança por causa da separação de seus pais.

- Marcio da Silva Lins, 20 anos, nasceu na aldeia Ofaié, em Brasilândia, filho de Neuza da Silva e José Lins Nantes, casado com Jaciele Brites, 15 anos, da etnia Guarani, nascida na Reserva Indígena de Dourados, quem conheceu depois da soltura do Presídio de Jateí. É cunhado do guarani Valdinei de Souza, já falecido, que morava em Passo Piraju e foi marido de sua irmã, Maria Aparecida Lins de Souza.

- Paulino Lopes, 24 anos, da etnia Kaiowa, nasceu na aldeia Te'ýi kue, em Caarapó, filho de Marciano Lopes, nascido naquela reserva, e Bernarda Savala, nascida em Passo Piraju e irmã de Teodocia Savala. Sua primeira esposa foi Tereza Murilha, da etnia Kaiowa, nascida em Caarapó e morta por enforcamento quando ele estava apenado no Presídio de Jateí, com quem teve 4 filhos: Celso, Dercil, Miguel e Cíntia. Está casado com Rosilene Marques, nascida em Caarapó, e com ela tem um filho nascido em maio de 2008. É primo de Sandra Arevalo Savala.

- Sandra Arevalo Savala, 24 anos, da etnia Kaiowa, nasceu na aldeia Limão Verde, em Amambai, filha de Saturnino Arevalo e Olacida Savala, falecidos quando ainda era criança. Foi criada pela sua avó paterna, Florentina Barbosa, nascida em Passo Piraju e expulsa da região juntamente com outras tantas famílias que ali viviam até a década de 1950. Sua avó a criou como filha na aldeia Guasuty, em Aral Moreira, é o maior motivo de seu vínculo com a região de Porto Cambira.

- Valmir Junior Savala, 20 anos, da etnia Kaiowa, nasceu na aldeia Te'ýi kue, em Caarapó, filho de Rosalino Ramão Gonçalves, 49 anos, e Ramona Savala, 62 anos, ambos nascidos em Passo Piraju. As famílias de seus pais foram expulsas da região de Porto Cambira e depois disso foram assentadas na aldeia Guasuty. Depois de ficar viúva, sua mãe casou-se com Hermínio Romero, réu desaparecido.

Existem, portanto, fortes indícios para acreditar que Passo Piraju é uma terra tradicionalmente ocupada por uma comunidade indígena, segundo seus usos, costumes e tradições atuais, sendo uma área imprescindível para sua reprodução física e cultural, conforme determina o Artigo 231, § 1º, da Carta Constitucional de 1988:

São terras tradicionalmente ocupadas pelos índios as por eles habitadas em caráter permanente, as utilizadas 
para suas atividades produtivas, as imprescindíveis à preservação dos recursos ambientais necessários a seu bem-estar e as necessárias a sua reprodução física e cultural, segundo seus usos, costumes e tradições.

Os indícios remetem ao fato de que antes de aquela área ser efetivamente ocupada por fazendeiros, a partir das duas últimas décadas da primeira metade do século $X X$, os Guarani e Kaiowa já a ocupavam tradicionalmente. Eles somente a deixaram porque sofreram um processo de esbulho perpetrado por terceiros e pelo próprio Estado brasileiro, com apoio de forças policiais como a "Captura".

A memória das pessoas mais idosas da comunidade chega à época da Companhia Mate Laranjeiras, que até a década de 1930 requisitava mão-de-obra indígena para a extração de erva-mate. Segundo Carlito de Oliveira, Isnailda Vilhalva, Teodocia Savala e Ramona Savala, nos últimos anos do monopólio da Companhia, por volta dos anos de 1937 e 1938, o chefe da empresa (Fazenda Campanário) desde Sanga Puitã até Passo Piraju era um correntino identificado sob o apelido de "Polaco". Com o fim do monopólio ele teria dito "de boca" aos líderes indígenas dali que eles e suas famílias podiam permanecer na área. Na época a população indígena da região estava concentrada nas proximidades de cinco riachos que deságuam no rio Dourados: Passo Piraju, Jaguaretekue, Yvyra Ovy, Ñundiary e Engáño. Segundo Carlito de Oliveira, estas cinco áreas somariam cerca de "30 mil alqueires" naqueles tempos, embora isto não tenha sido possível de apurar durante as diligências periciais.

Com a abertura dos projetos estatais e particulares de expansão das frentes econômicas de colonização nas antigas terras da Companhia, ocorrida nas décadas de 1940 e 1950, a comunidade de Passo Piraju passou a conhecer os novos donos da terra, os donos "no papel", conforme salientaram. Em 1943 teria chegado o primeiro fazendeiro na região. Depois dele veio o segundo, em 1948, e logo em seguida o terceiro, na década seguinte. Todos eles até então não se incomodaram com a presença indígena no lugar, deixando-lhes plantar e extrair da mata o seu sustento. Somente com a chegada do quarto fazendeiro, em fins da década de 1950, teria sido exigida sua saída dali pelo novo "dono da terra", conforme tratado anteriormente. Isto ocorreu em um contexto marcado pela expansão das frentes agropecuárias no antigo sul de Mato Grosso.

Com este processo de esbulho ocorreu o que na geografia crítica e na antropologia histórica se conhece como "desterritorialização", quer dizer, a mudança involuntária de uma população de seu território tradicional para outro lugar, onde se fez necessário adaptar sua cultura a uma nova realidade espacial. Esta adaptação é chamada de "territorialização", pois exige certas mudanças em termos socioculturais, o que, no caso em tela, nada teve a ver com a perda da distintividade étnica ou do sentimento de indianidade. Os Guarani e Kaiowa, por sua vez, chamam esta situação histórica de "esparramo" ou ñemosarambipa (vide BRAND, 1993, 1997). 
Este evento foi um divisor de águas na história da comunidade indígena do Passo Piraju, pois a expulsão sofrida fez com que a população fosse repartida nas aldeias Chapiru, Ka'aguy Rusu, Ita Poty, Guasuty e outras que foram oficializadas como "reservas indígenas". Posteriormente estas aldeias foram denominadas pelo SPI segundo o núcleo de povoamento não-indígena onde estavam localizadas: Dourados, Panambi, Amambai, Aral Moreira, etc.

As famílias que viviam em um lugar chamado Engáño, nas adjacências da atual região de Porto Cambira, foram levadas para a aldeia Bororó, na Reserva Indígena de Dourados; as que ocupavam Passo Piraju foram distribuídas pelas regiões de Aral Moreira, Caarapó e Amambai.

Os indígenas periciados são conhecedores desta história, pois ela está registrada na memória social coletiva da comunidade de Passo Piraju.

\subsection{OS EXAMINADOS VÊEM O INDÍGENA CARLITO DE OLIVEIRA COMO UM LÍDER OU CACIQUE?}

Sim. Os réus examinados e os demais membros da comunidade de Passo Piraju veem Carlito de Oliveira "como um líder ou cacique", isto é, como uma liderança política ${ }^{24}$. O acusado é um líder político importante para a articulação e organização do grupo com vistas à reivindicação de direitos junto às autoridades governamentais.

Em situações como a de Passo Piraju, líderes políticos como Carlito de Oliveira são importantes para manter a coesão, a disciplina e a unidade do grupo em torno de objetivos comuns. Geralmente contam com o apoio de líderes religiosos internos por eles chamados de ñanderu, como é o caso do rezador Firmino Martinez, quem veio da aldeia Takuara, localizada em Juti, para Passo Piraju no início do mês de dezembro de 2007.

O cacique é aquele que geralmente intermedeia a relação da comunidade com a sociedade envolvente, sobretudo com instituições como FUNAI, FUNASA (Fundação Nacional de Saúde), MPF, governo estadual, prefeituras municipais, universidades, organizações nãogovernamentais (ONG's) etc. Isto não significa, vale a pena registrar, que os caciques sejam indivíduos totalmente integrados à comunhão nacional ou que sua liderança seja uma unanimidade entre seus pares.

Carlito de Oliveira atuou não apenas na catalisação do desejo de famílias tradicionais que desejavam retornar para seu lugar de origem (Passo Piraju), mas também se tornou referência social e política para pelo menos 23 crianças por ele adotadas, chamadas em guarani de

\footnotetext{
${ }^{24}$ De acordo com a enciclopédia Wikipédia: "O cacique (do arauaque do Haiti cachique, 'chefe político', pelo espanhol cacique, idem) é a denominação da suposta chefia indígena difundida por portugueses e espanhóis entre os povos com os quais entraram em contato. Cada um dos grupos étnicos da América do Sul possui tanto uma denominação quanto uma concepção própria para suas lideranças. Mburovixá é a denominação empregada pelos povos Guarani para seus principais. Entre os Tupi as denominações eram mититихаиа, тигихаиа, tubixaba e tuxaиa. Curaca era a denominação de uma espécie de prefeito entre os Inca das terras da alta América no tempo da invasão e colonização européia" (Wikipédia - A Enciclopédia Livre. Disponível em: $<$ http://pt.wikipedia.org/wiki/Cacique $>$. Acesso em: 28 mai. 2008).
} 
guácho. Este é o termo empregado às crianças abandonadas pelos seus genitores e que crescem agregadas a outras famílias próximas (avós, tios etc.), seja na condição de "adotadas" (ta'ýra anga ou memby anga) ou na condição de "serviçais" (tembiguái) (vide PEREIRA, 2002).

Em que pese as suas contradições, o gesto de incluir uma criança guácho na parentela não deixa de ser significativo entre os Guarani e Kaiowa, pois, segundo Levi Marques Pereira (2002, p.185), nestes grupos parece impossível pensar em alguém sem parentes. As mães e os pais biológicos dos guácho procedem de várias aldeias. No entanto, as crianças criadas por Carlito de Oliveira cresceram na Reserva Indígena de Dourados, onde ele residia com sua primeira esposa.

Os guácho costumam ser fiéis aos seus "pais adotivos" porque entre os Guarani e Kaiowa o parentesco não é um mero vínculo de consanguinidade, mas uma relação socialmente construída na coletividade. E esta coletividade nada mais é que uma rede de relações sociais empiricamente observáveis por meio dos métodos científicos empregados para a realização deste laudo pericial.

Por ocasião da "retomada" da terra na localidade de Porto Cambira, muitos guácho acompanharam Carlito de Oliveira até Passo Piraju. Depois do ocorrido no dia 1\%/04/2006 a maioria deles voltou à aldeia Bororó, na Reserva Indígena de Dourados. Portanto, o "esparramo" desses guácho atesta um grande impacto negativo causado por conta dos desdobramentos advindos da ação.

3.6. OS RÉUS POSSUEM DISCERNIMENTO ENTRE O CERTO E O ERRADO? EM CASO POSITIVO ESSE DISCERNIMENTO É EQUIPARÁVEL AO DE UM HOMEM BRANCO MÉDIO?

Sim. Os réus possuem discernimento entre certo e errado, mas este discernimento não "é equiparável ao de um homem branco médio", pois os mesmos não estão incorporados à comunhão nacional e possuem um sistema sociocultural distinto do da sociedade envolvente. Entre eles, portanto, o certo e o errado são definidos a partir de uma lógica cultural e de uma organização social que os distinguem em relação às pessoas integradas à comunhão nacional.

Entre os seres humanos a noção e a experiência de agir certo ou errado são construídas e condicionadas culturalmente. Não estão inscritas, portanto, na natureza humana e nem fazem parte da carga genética de cada indivíduo, visto que o Homo sapiens é um ser social e, como tal, é em sociedade que desenvolve valores sobre o certo e o errado a partir das regras sociais e da cultura do grupo a que pertence.

Para exemplificar esta afirmativa, pode-se mencionar o episódio, ocorrido no segundo semestre de 2005 e divulgado pela imprensa nacional, da recusa de muitas famílias guarani e kaiowa que vivem na Reserva Indígena de Dourados em ir morar em habitações populares ali construídas com recursos da União. Essas residências foram batizadas pelos indígenas de "casas de chocolate", em alusão a sua fragilidade muitas delas desabaram antes de serem ocupadas - e ao tipo de tijolo 
usado nas construções, cujo formato lembra uma barra de chocolate. Esta recusa teve a ver, também, com o fato de eles constatarem que o banheiro ficava dentro da casa. Ocorre que para muitas famílias indígenas o lugar onde elas residem, onde preparam e consomem alimentos em volta de um fogão construído com pedras delimitadoras, não pode ser o mesmo espaço onde haja um ponto para as pessoas poderem urinar e defecar. Para a sociedade envolvente, no entanto, ter banheiro dentro da casa é tão importante a ponto de muitos transformarem seus aposentos em "suítes", isto é, em dormitórios com banheiro incluso.

Este é apenas um exemplo do quanto que a sociedade envolvente desconhece o modus vivendi dos indígenas estabelecidos na região, embora pense exatamente o contrário. No caso em tela, caso o poder público tivesse contado com uma consultoria antropológica competente, certamente que o projeto das "casas de chocolate" poderia ter sido mais eficaz desde o início de sua implementação.

Neste sentido, faz-se necessário ainda explicar que o marco de comparação explicitado na expressão "homem branco médio" é bastante imprecisa e por demais abstrata. Ao mesmo tempo em que reduz a pluralidade étnica/racial e socioeconômica da sociedade nacional, limitase a tratar apenas do homem e não da mulher, do branco e não das pessoas de outra cor, como as negras.

\subsection{QUAL É O RESPEITO QUE OS RÉUS DÃO À VIDA?}

Para os réus a vida é dividida em duas partes, uma biológica e outra espiritual. Ambas são sobremaneira importantes e respeitadas em sua plenitude, de acordo com seus usos, costumes e tradições.

Acreditam na vida após a morte e na dualidade da alma, isto é, que possuem duas almas, uma carnal (ãguéry) e outra espiritual (ñe'ẽ). A primeira, ãguéry, ou ãgue dependendo da etnia, permanece presa ao plano material, acompanha o defunto em seu túmulo e não deve ser incomodada de forma alguma, sob pena de sair da sepultura e causar perturbações aos vivos (doenças, conflitos políticos etc.). A segunda, ñe'ẽ, quando se desprende da pessoa por ocasião de sua morte, segue para o céu, onde permanece em um mundo espiritual abaixo do mundo onde está localizado o panteão das divindades. No entanto, pode acontecer de a alma espiritual se separar do corpo de um indivíduo antes de sua morte, o que ocorre por motivos variados, dentre eles doenças e feitiçarias. Quando isto acontece, a pessoa se transforma em uma espécie de "zumbi", situação esta que pode preceder a uma tentativa de suicídio (vide CHAMORRO, 1995; PEREIRA, 1999, 2004; EREMITES DE OLIVEIRA, 2007).

A vida para eles e para toda a comunidade de Passo Piraju, assim como para os Guarani e Kaiowa em geral, é tão valorizada que mesmo em situações da iminência de conflito bélico eles procuram evitar chegar às vias de fato. Assim o fazem por meio da diplomacia ou retirando-se estrategicamente do local, como muitas famílias têm feito ao deixarem a Reserva Indígena de Dourados nos últimos anos. Em casos extremos, porém, tendem a agir coletivamente em defesa do grupo a que pertencem. Nessas ocasiões podem mesmo ceifar a 
vida daqueles que os venham a agredir e/ou a colocar em risco suas vidas.

\subsection{OS RÉUS POSSUEM DOMÍNIO DO IDIOMA PORTUGUÊS? DESCREVER INDIVIDUALMENTE?}

Não. A língua portuguesa permanece, inclusive para os réus mais jovens, como uma segunda língua: (1) Carlito de Oliveira entende razoavelmente e fala pouco; (2) Ezequiel Valensuela entende e fala pouco; (3) Hermínio Romero, segundo foi possível saber pela sua esposa, Ramona Savala, entende/entendia pouco e fala/falava pouco, assim como ela; (4) Jair Aquino Fernandes entende e fala razoavelmente; (5) Lindomar Brites de Oliveira entende e fala razoavelmente; (6) Marcio da Silva Lins entende e fala razoavelmente; (7) Paulino Lopes entende e fala pouco; (8) Sandra Arevalo Savala entende pouco e fala pouco; (9) Valmir Junior Savala entende e fala razoavelmente ${ }^{25}$.

Alguns linguistas avaliam mesmo que o português falado por vários povos indígenas não é o português padrão falado pela maioria da população brasileira, mas um português-índio discursivamente singular a cada etnia indígena: português-kaiowa, português-guarani, portuguêsofaié, português-terena etc. Trata-se de uma língua portuguesa que contém estruturas de línguas nativas como forma de afirmação da diferença cultural e da identidade étnica. Exemplo disso é a brilhante tese de doutorado em linguística defendida em 1996 por Terezinha de Jesus Machado Maher, denominada Ser professor sendo índio: questões de língua(gem) e identidade (MAHER, 1996). Portanto, ainda que alguns réus possam parecer falar razoavelmente a língua portuguesa, a comunicação entre eles e o mundo jurídico é algo mais complexo do que se pode supor em um primeiro momento.

Constatou-se in loco que na comunidade de Passo Piraju as pessoas de origem Guarani falam melhor o português do que as de origem Kaiowa. De um modo geral, o intenso contato que tiveram com a população envolvente (fronteiriços, paraguaios, ervateiros etc.) redundou na incorporação de empréstimos de mais palavras do espanhol que do português na sua língua materna. Exemplos: hermáno ("irmão"), ekuéla ("escola"), che joelho ("meu joelho") etc.

\subsection{OS RÉUS, NO DIA DOS FATOS, ACREDITAVAM QUE ESTAVAM DEFENDENDO SUA TERRA DE INVASORES?}

Sim. Este é um fato insofismável, conforme consta nas respostas dadas aos quesitos anteriores, sobretudo o de $n^{\circ} .2 .2$, formulado pelo Juízo.

\footnotetext{
25 Os termos "bem", "razoavelmente" e "pouco" são categorias que o CNPq (Conselho Nacional de Desenvolvimento Científico e Tecnológico) utiliza para classificar o domínio de línguas os pesquisadores que atuam no país, cujos currículos estão disponíveis na Plataforma Lattes (vide www.cnpq.br).
} 


\subsection{QUAL É A NOÇÃO QUE OS RÉUS POSSUEM SOBRE A JUSTIÇA?}

Todos os réus percebem o poder judiciário brasileiro como uma instituição ou um conjunto de leis da e para a sociedade nacional, que serve para mantê-los submetidos a uma situação de dominação e submissão.

$\mathrm{Na}$ perspectiva indígena a noção de justiça tem a ver com as expressões teko joja e teko porã. "Teko" é o modo de ser guarani e kaiowá, "joja" significa igual e "porã" quer dizer bom. Desse modo, fazer justiça é ajustar o desigual, ambojoja; a justiça é a instância e o lugar ( $h a$ ) onde se exerce essa ação, o teko mbojojaha. Ser objeto da justiça indígena enquanto "acusado" é ser tratado como alguém que vive de forma perigosa e má, chamada hereko meguãmbýramo aiko, comparável às epidemias mbapáramo aiko.

\subsection{OS RÉUS SE ACHAM INJUSTIÇADOS POR ESTAREM PRESOS?} 2.2 .

Sim. Ver respostas dadas aos quesitos do Juízo, sobretudo o de $n^{\circ}$.

\subsection{OS RÉUS ESTÃO ARREPENDIDOS POR TEREM ATENTADO CONTRA AS VIDAS DOS POLICIAIS CIVIS?}

Sim. No entanto, é preciso considerar, conforme explicado na resposta dada ao quesito do Juízo de $n^{\circ}$. 2.2, que, quando indagados sobre o assunto, os réus consideraram o termo "arrependimento" como sentimento de medo e não como atitude contrária àquela tomada no dia $1 \%$ 04/2006. Valeram-se da expressão remby asy (rembyasy ou rombyasy) para manifestar sentimento de intensa e dor, tristeza e malestar pelo acontecido.

\subsection{3. À ÉPOCA DO CRIME OS RÉUS ERAM CAPAZES DE ENTENDER O CARÁTER ILÍCITO DO FATO OU DE DETERMINAR-SE DE ACORDO COM ESSE ENTENDIMENTO?}

Não. Este assunto consta analisado nas respostas dadas aos quesitos do Juízo, em especial os de número 2.2. e 2.4.

O "caráter ilícito do fato" a que se refere o quesito é um juízo de valor com o qual os réus não concordam, visto que agiram de acordo com o que consideram lícito: defender a vida e a terra de uma coletividade indígena contra pessoas estranhas que se comportaram de forma agressiva e belicosa.

\subsection{OS RÉUS PODEM SER DEFINIDOS COMO IMPUTÁVEIS PARA EFEITOS PENAIS?}

Se a definição de imputabilidade for "a aptidão do ser humano compreender que determinado fato não é lícito e de agir em conformidade com esse entendimento", segundo conceito apresentado 
pelo juiz federal Roberto Lemos dos Santos Filho (s.d.), da Primeira Vara de Bauru, São Paulo, a resposta é $\operatorname{sim}^{26}$. Esta resposta positiva leva ainda em consideração as respostas dadas aos quesitos do Juízo e aos apresentados pelas partes.

\subsection{OS RÉUS DEMONSTRAM POSSUIR PERSONALIDADE VIOLENTA OU AGRESSIVA?}

Não. Pelo contrário, os réus demonstraram amabilidade e conduta pacífica diante dos experts do Juízo e da assistente técnica do Ministério Público Federal. A própria comunidade de Passo Piraju não percebe qualquer um dos réus como possuidor de "personalidade violenta ou agressiva", ainda que em alguns momentos eles possam ter divergências políticas com os acusados, o que é comum entre grupos humanos em geral.

\subsection{6. É POSSÍVEL QUE OS RÉUS TENHAM CONFUNDIDO OS POLICIAIS COM JAGUNÇOS?}

Sim. Esta é uma conclusão insofismável à luz da antropologia, conforme explicado no quesito do Juízo de $\mathrm{n}^{\circ}$. 2.2 e nos subsequentes.

\subsection{OUTRAS CONSIDERAÇÕES QUE OS PERITOS ENTENDEREM NECESSÁRIAS}

As narrativas dos réus e de outras pessoas da comunidade de Passo Piraju, conforme explicado nos quesitos anteriores e nos subsequentes, sugerem a existência de uma série de vícios que comprometem a legitimidade da prisão dos acusados e o conteúdo dos depoimentos que teriam dado à Polícia Civil na sede do DOF em Dourados.

Os fatos descritos sugerem ainda a existência de práticas que caracterizam o abuso de poder por parte de agentes policiais e carcerários, bem como a explícita violação dos direitos humanos, inclusive com métodos de tortura comuns em regimes ditatoriais de todo tipo e explicitamente incompatíveis com os princípios elementares que fundamentam o Estado Democrático de Direito.

\section{Quesitos da AGU/PGF/FUNAI}

4.1. PROCEDIDO AO EXAME DOS SILVÍCOLAS ACUSADOS, DIGAM OS SENHORES PERITOS COMO PODEM SER CLASSIFICADOS DIANTE DOS TERMOS DOS ART. $4^{\circ}$ DO ESTATUTO DO ÍNDIO (LEI FEDERAL No. 6.001, DE 19 DE DEZEMBRO DE 1973), ISTO É, SE SÃO CONSIDERADOS ISOLADOS, EM VIAS DE INTEGRAÇÃO OU INTEGRADOS.

\footnotetext{
${ }^{26}$ SANTOS FILHO, Roberto L. dos. S.d. Índios e imputabilidade penal. Bauru: s.e., 10p. (não publicado) 
Os réus podem ser considerados, por força da lei e conforme explicado na resposta dada ao quesito do Juízo de $n^{\circ}$. 2.4, como "em vias de integração". Entrementes, de um ponto de vista antropológico - e sem recorrer a um alhures no campo da "futurologia" - é possível afirmar que esta "integração" não ocorrerá até o final de suas vidas.

4.2. TINHAM OS ACUSADOS, NA OCASIÃO DOS FATOS QUE ORIGINARAM A AÇÃO PENAL, CONDIÇÕES DE AVALIAR O CARÁTER ILÍCITO DE SUA CONDUTA DE ACORDO COM O "HOMEM MÉDIO CIVILIZADO".

Não. A explicação para esta negativa consta nas respostas apresentadas aos quesitos do Juízo.

\subsection{OS ACUSADOS APRESENTAM OU APRESENTAVAM ALGUM INDÍCIO DE DESVIO DE CONDUTA NO MEIO TRIBAL OU PERICULOSIDADE.}

Não. Uma explicação para esta negativa consta nas respostas dadas aos quesitos do Juízo e ao quesito do Ministério Público Federal de $\mathrm{n}^{\circ}$. 3.15 .

4.4. PROCEDIDO AO EXAME PERICIAL, DIGAM, OS SENHORES PERITOS QUAIS AS REAÇÕES DEMONSTRADAS PELOS ACUSADOS, GRAU DE PERICULOSIDADE E DE INTEGRAÇÃO À COMUNHÃO NACIONAL, BEM COMO SEJA PORMENORIZADO HISTÓRICO DOS FATOS QUE ANTECEDERAM A AÇÃO DELITUOSA.

Uma resposta à altura para este quesito consta nas respostas apresentadas aos quesitos do Juízo e do Ministério Público Federal.

4.5. DIGAM OS EXPERTS O QUE LEVOU OS ACUSADOS À PRÁTICA DAS AGRESSÕES CONTRA AS VÍTIMAS E SE TAL PROCEDIMENTO CORRESPONDE À PRÁTICA E AOS COSTUMES TRIBAIS EM SITUAÇÕES SEMELHANTES.

A resposta para este quesito consta nas respostas dadas aos quesitos do Juízo e do Ministério Público Federal. Todavia, deve-se reiterar que a ação se deu no interior de um ambiente de conflitos ligados à disputa pela terra, no qual os três policiais civis foram confundidos com "jagunços" ou "pistoleiros". Muitos desses conflitos foram comunicados ao próprio Ministério Público Federal em Dourados.

\subsection{OS ACUSADOS POSSUEM DOMÍNIO DO IDIOMA PORTUGUÊS?}

Não. A resposta para este quesito consta na resposta dada ao quesito do Ministério Público Federal de $n^{\circ}$. 3.8. Acrescenta-se a esta resposta o fato de a perita do Juízo ser uma das maiores autoridades no que se refere aos estudos linguísticos sobre o idioma guarani. Seu currículo profissional está disponível na Plataforma Lattes do CNPq (vide www.cnpq.br). 
Espaço Ameríndio

4.7. EM FACE DO CONFLITO FUNDIÁRIO DEFLAGRADO ENTRE OS ACUSADOS E FAZENDEIROS DA REGIÃO, É POSSÍVEL AFIRMAR QUE A AÇÃO DOS ACUSADOS OCORREU DE FORMA INDIVIDUALIZADA, PRÉ-ORDENADA OU DE FORMA COLETIVA?

A ação dos acusados correu de forma coletiva, mas não de maneira pré-ordenada, conforme explicado na resposta dada ao quesito do Juízo no. 2.2 e seguintes.

\subsection{OS ACUSADOS AGIRAM EM DEFESA DOS INTERESSES COLETIVOS DO GRUPO TRIBAL?}

Sim. Ver na resposta dada ao quesito do Juízo $\mathrm{n}^{0} .2 .2$ e seguintes.

4.9. DESCREVAM OS SENHORES PERITOS A AÇÃO DOS ACUSADOS EM COTEJO COM OS PARÂMETROS CULTURAIS DO GRUPO ÉTNICO A QUE PERTENCEM.

A descrição da "ação dos acusados em cotejo com os parâmetros culturais do grupo étnico a que pertencem" consta na resposta dada ao quesito do Juízo $\mathrm{n}^{\circ} .2 .2$ e seguintes.

4.10. QUAL O ESCOPO PERQUIRIDO PELOS ÍNDIOS NA AÇÃO PRATICADA CONTRA AS VÍTIMAS.

O escopo ou a intenção dos acusados "na ação praticada contra as vítimas" está descrito e analisado na resposta dada ao quesito do Juízo $\mathrm{n}^{\circ} .2 .2$ e seguintes. A intenção de alguns dos acusados, sobretudo dos dois réus confessos, foi a de defender energicamente a vida e a terra da comunidade indígena de Passo Piraju contra estranhos armados por eles vistos como "jagunços" ou "pistoleiros".

4.11. OS COMPONENTES DA ETNIA GUARANI-KAIOWA, TEM COMO COSTUME A NÃO ASSIMILAÇÃO E ENTENDIMENTO DOS VALORES QUE TEM A SOCIEDADE ENVOLVENTE E NÃO ÍNDIA?

Não. No entanto, conforme explicado na resposta dada aos quesitos do Juízo e seguintes, esta "assimilação e entendimento dos valores que tem a sociedade envolvente e não índia" ocorre segundo seus usos, costumes e tradições, quer dizer, são reelaborados e ressignificados dentro de uma lógica cultural particular de agir e perceber o mundo.

4.12. TRADICIONALMENTE OS COMPONENTES DA ETNIA GUARANIKAIOWA, EM SEU EMPIRISMO CONCEITUAL, É INVESTIDA OU IMBUÍDA A PROMOVER ATAQUES CONTRA PESSOAS?

Se a expressão "empirismo conceitual" foi usada como um termo análogo ao de cultura tradicional, a resposta é não, exceto em 
situações de extremo perigo para a comunidade, assunto este tratado nas respostas apresentadas aos quesitos do Juízo, sobretudo o de $\mathrm{n}^{\circ}$. 2.2.

Ademais, como apontado anteriormente, em antropologia o termo "tradicional" não tem um status fixo, tampouco está ancorado no passado mais remoto da existência do grupo. "Tradicional" é o que o grupo em algum momento de sua história atribui ao sentido de tradicional, isto é, aquilo que passa a ser visto como legítimo e fundamental para assegurar a continuidade física e cultural de uma comunidade indígena. A tradição é, portanto, constantemente reelaborada e ressignificada.

No âmbito da história da sociedade chamada ocidental, o renascimento europeu é um exemplo muitíssimo conhecido dessa dinâmica cultural. Foi no século XVI, depois de séculos de ruptura e esquecimento, que teóricos, artistas e intelectuais de todas as áreas de conhecimento se remeteram à antiguidade clássica, postulando um suposto retorno à tradição, para dar início a profundas transformações sociais pelas quais passava a Europa.

As etnografias e os estudos etno-históricos produzidos sobre os Guarani e Kaiowa, tanto no Brasil quanto no Paraguai, além de outros povos de língua guarani, como os Mbyá, atestam que, pelo menos nos últimos oitenta anos, esses indígenas eram/são contrários à prática de toda sorte de violência. Para eles a moderação ou serenidade é uma das qualidades supremas da pessoa. Por isto buscam alcançar a perfeição humana, baseada na serenidade, na generosidade e no desenvolvimento do dom da palavra (vide NIMUENDAJU, 1987 [1914], SCHADEN, 1974 [1954]; MELIÀ et al., 1976; MELIÀ, 1988, 1990, 2004; FERNANDES DA SILVA, 1982; PEREIRA, 1999, 2003, 2004, 2006, 2007; MONTEIRO, 2003; CHARSE-SARDI, 1990; BRAND, 1993, 1997, CHAMORRO, 1995; CIMI et al., 2000; THOMAZ DE ALMEIDA, 2001; MOREIRA DA SILVA, 2002; GRÜNBERG e AOKI, 2004; STEFANES PACHECO, 2004; ADRIANA DA SILVA, 2005; LANDA, 2005; MACIEL, 2005; MURA, 2006).

$\mathrm{Na}$ história de alguns povos de língua guarani que vivem no Paraguai, culturalmente próximos dos Guarani e Kaiowa que vivem em Mato Grosso do Sul, encontram-se evidências linguísticas de uma prescrição arcaica.

No caso dos chamados Ava-Guarani, sabe-se que eles possuem um código ético-penal conhecido como o tuguy ñeẽ repy, cuja tradição significa "o preço do sangue derramado". Este código prevê que todo homicídio, incluindo dano corporal seguido de doença e morte, deve ser pago com a "morte". Segundo o respeitado antropólogo paraguaio Miguel Chase-Sardi (1992, p.81), esta morte se efetua simbolicamente ao entregarem os homicidas à polícia paraguaia, castigo ainda pior para os indígenas que cometem crime.

Um código semelhante foi registrado por mais um renomado etnógrafo paraguaio, o antropólogo Leon Cadogan (1959), entre os Mbyá do Sul do Paraguai, um outro povo indígena de língua guarani. Segundo observou, a pessoa que por desamor tenha ferido furtivamente a seu semelhante, ou que tenha desolado o lar de um próximo, deveria ser morta para que houvesse justiça. 
Além dessas duas referências não há qualquer indício de que esses povos de língua guarani, incluindo os Guarani e Kaiowa, se orientem hoje em dia por padrões comportamentais ancorados na violência, ou que tenham medidas preventivas ou punitivas que possam ser classificadas como violentas. Ao contrário, para eles as virtudes cardeais são as seguintes: serenidade, mansidão e longanimidade ou tolerância. A violência nas aldeias e nas cidades vizinhas é considerada um comportamento desviante, um "modo de ser quente" ou teko aku. Por isso uma das principais funções da liderança religiosa - ñanderu quando homem e ñandesy quando mulher - é fazer que as pessoas "moderem ou esfriem seu falar", falado em guarani como oñoñe'ẽ emboro'y. Por outro lado, este empenho pode indicar que esses grupos têm consciência de que - como todo ser humano - são potencialmente violentos e que as consequências do ato violento são das mais funestas para eles. Portanto, há que reprimir, controlar e suplantar a violência pela serenidade, mansidão e longanimidade ou tolerância.

\subsection{COMO REAGEM OS GUARANI-KAIOWA QUANDO PERCEBEM} QUAISQUER AMEAÇAS CONTRA A SUA COMUNIDADE?

Este quesito consta parcialmente respondido nas respostas apresentadas ao quesito do Juízo de $n^{\circ}$. 2.2 e subsequentes. Todo modo, não há como apresentar uma resposta generalizante para todos os Guarani e Kaiowa, pois a reação vai depender da situação, da atuação das lideranças e do grau de tensão represada no seio do grupo. No caso de ameaça à sua integridade física, a reação mais comum é abandonar o ambiente de conflito e afastar-se da situação. Contudo, existem exceções e este foi o caso da violência praticada contra os três policiais civis no dia 1\%/04/2006.

No que se refere aos Guarani e Kaiowa estabelecidos no estado de Mato Grosso do Sul, pode-se dizer que até a década de 1980 esta reação se caracterizou por certa passividade, resignação e depressão psíquica geral frente às ameaças. Foi isso o que registrou o antropólogo brasileiro Egon Schaden (1974 [1954], p.177) na década de 1940, ocasião em realizou pesquisas etnográficas em várias comunidades indígenas, incluindo os Kaiowa da atual Reserva Indígena Panambizinho. Na época as terras guarani e kaiowa estavam sendo loteadas e ocupadas por estranhos, e disso resultou, como dito antes, no esparramo ou ñemosarambipa de muitas famílias indígenas; parte delas ficou reclusa nas reservas então reconhecidas pelo Estado brasileiro.

A esta situação os Guarani e Kaiowa reagiram com mania de perseguição, fuga da realidade e, em alguns casos, com tanatomia e suicídio. Os líderes religiosos, desesperados e temerosos de serem expulsos do último rincão que ocupavam, intentaram precipitar a destruição do mundo e partir para o além. Este tipo de reação costuma ser chamada de "apocalíptica", segundo linguagem recorrente nos estudos antropológicos sobre religião.

Mas a situação começou a mudar em fins da década de 1970, quando os grupos indígenas de forma mais ampla começam a se 
mobilizar e organizar pela reivindicação e reconhecimento de seus direitos. Isto gerou um movimento étnico-social, ou seja, um movimento em que os indígenas são os principais protagonistas, ainda que eles possam contar com vários apoiadores, como o CIMI (Conselho Indigenista Missionário). Significa dizer que, ao contrário do que é divulgado pelo senso comum, os Guarani e Kaiowa são atores sociais que atuam na construção de sua própria história e não meros fantoches nas mãos de terceiros (PEREIRA, 2003; ADRIANA DA SILVA, 2005; PEREIRA e EREMITES DE OLIVEIRA, 2007).

Este movimento indígena se estruturou na década de 1980, ao mesmo tempo em que eclodiam outros tantos movimentos étnicos na América Latina, conforme se pode atestar com o estudo do equatoriano Pablo Dávalos (2005). Passou a ter maior visibilidade com o fim do regime militar (1964-1985) e a promulgação da Constituição Cidadã de 1988. Desde então os grupos Guarani e Kaiowa recorrentemente reagem, frente à ameaça de desterritorialização ou na condição de desterritorializados, aproximando-se dos lugares que consideram seus territórios, ocupandoos ou assentando-se nas imediações. A partir daí pressionam os órgãos competentes, sobretudo a FUNAI, a agilizar os trâmites legais para sua regularização junto ao Estado.

4.14. HAVIA CONFLITO ANTERIOR, DE QUAISQUER ORIGENS, AO FATO OCORRIDO NO LOCAL DO EVENTO, DIA 01.04.2006?

Sim. Para maiores esclarecimentos sobre o assunto, ver a resposta dada ao quesito do Juízo de $\mathrm{n}^{\circ} .2 .2$ e os seguintes.

4.15. HAVIA ACORDO ANTERIOR ENTRE AS AUTORIDADES POLICIAIS POR CONSULTAREM A FUNAI ANTES DE QUALQUER AÇÃO PARA O INGRESSO EM COMUNIDADES INDÍGENAS?

Sim. Havia um acordo desta natureza, a exemplo dos entendimentos mantidos por ocasião da implementação da Operação Sucuri, assunto este tratado na resposta ao quesito do Juízo de $\mathrm{n}^{\circ}$. 2.2. Entretanto, salvo melhor juízo os policiais civis que na tarde do dia $1 \%$ 4/2006 entraram na área de 40,8 hectares onde está acomodada a comunidade de Passo Piraju, não tinham prévia autorização da FUNAI para ali estar. Também não foram convocados a auxiliar a Polícia Federal no desenvolvimento de alguma atividade naquela localidade. Na opinião do juiz federal Roberto Lemos dos Santos Filho (2006), esta situação "indica ocorrência de violação à ordem jurídica".

4.16. PODEM OS EXPERTS EXPLICAR ANTROPOLOGICAMENTE SE OS EXAMINADOS/RÉUS POSSUEM O DISCERNIMENTO E ENTENDER O CARÁTER DA ILICITUDE COMETIDA?

Conforme explicado anteriormente, ao tempo da ação os réus não possuíam "o discernimento e entender o caráter da ilicitude cometida”, haja vista que para eles não há ilicitude no ato de defender 
a vida e a terra de uma coletividade indígena. Foi possível perceber que a capacidade de discernir e entender dos indígenas examinadas corresponde aos parâmetros tradicionais de formação da pessoa nas comunidades guarani e kaiowa.

A etnografia dos atuais grupos de língua guarani mostra que alcançar a maturidade de entendimento é um grande desafio para as pessoas, sobretudo no âmbito psíquico-espiritual.

A atitude predominante na educação de uma criança é não interferir e, menos ainda, forçar seu desenvolvimento. Este processo deve ser apenas acompanhado e apoiado psíquica e espiritualmente. De certa forma, este tipo de comportamento se arraiga na crença de que a individualidade psíquica é pré-existente, pois a alma, como projeto, já nasce pronta. Para eles a questão educacional adquire características peculiares pela ideia de que as crianças são entes queridos que retornam do outro mundo. Com exceção das crianças guácho, tratadas com rigor e vigilância por não terem vínculo estável com parentes, além da suspeita de uma tendência à violência e criminalidade, também as crianças kaiowa crescem livres e, quando maiores, nada apreciarão mais que sua liberdade. Porém, não se pode inferir do exposto que as crianças crescem sem nenhum controle de seus impulsos. Ao contrário, o domínio da agressividade é discutido constantemente e nele investem muita energia os homens e as mulheres que desejam galgar destaque espiritual. Eles acreditam ter próximo a sua alma divina e divinizadora uma alma classificada - na falta de melhor tradução - de "animal ou terrena". Esta alma infunde má vontade para cultivar os valores tradicionais do grupo: a perseverança na oração e nos exercícios espirituais, chamados ñembo'e, a prática do amor ao próximo, mborayhu, e capacidade de renúncia ou "grandeza de coração", denominada py'a guasu.

Esta convergência do divino e do animal divide o ser humano. A "ira" e o "ato de ofender" são, entre outras atitudes, as que "bifurcam sua alma”. E não só a presente geração corre esse risco, mas também os personagens míticos são protagonistas de narrativas de caráter epônimo referentes à ira. Esses episódios e outros advertem sobre as tragédias que a ira pode acarretar, de modo que atitudes como "ter autodomínio" e "ser prudente" integram o arakuaa, "saber ou conhecer o tempo-espaço", e o arandu, "sentir ou perceber o tempo-espaço", que expressam o conceito de maturidade de entendimento entre os Guarani e Kaiowa.

Além disso, nas aldeias kaiowa em Mato Grosso do Sul, um verbo muito significativo para compreender o processo de socialização e a maturidade social das pessoas é ñemopu'â, que quer dizer "fazer erguer" e se aplica ao processo de constituição das relações de parentelas e do tekoha, que é o "espaço físico, social e simbólico" vital para a reprodução do grupo e a maturação física, psíquica, social e espiritual de seus integrantes. Esse 'fazer erguer' é motivado por uma força cósmica exterior aos seres humanos. De modo que ao se erguer uma pessoa se ergue também o cosmos. O líder espiritual é quem capta esta força cósmica e, assimilando-a, levanta e faz com que as coisas existam, gerando em seu interior a força vital para que elas se sustentem. Apoiado em três décadas de convivência com os grupos Guarani e Kaiowa, Levi 
Marques Pereira, em sua tese de doutorado, ressalta a necessidade de reconhecer a importância da parentela no debate sobre o desenvolvimento e a maturidade nos grupos Kaiowa, pois "existir é erguer-se sobre os pés, é ter vontade, movimento, intencionalidade [...]. Para existir é necessário ter ânimo para erguer-se" (PEREIRA, 2004, p.224). Saúde física e equilíbrio psicológico pressupõem a sociabilidade livre e descontraída de parentes próximos. Para manter fluída a comunicação social, uma pessoa deve estar ligada a um fogo, isto é, ter vínculos estáveis com parentelas.

\subsection{QUAL É A PERCEPÇÃO TRADICIONAL QUE POSSUEM OS EXAMINADOS SOBRE A QUESTÃO LIGADA AOS CRIMES, COM CONHECIMENTO PRÓPRIO DE SUA CULTURA?}

Esta pergunta consta respondida nos quesitos anteriormente analisados, sobremaneira os de $\mathrm{n}^{\circ}$. 2.2, 2.3, 2.4, 3.1, 3.2, 3.6, 3.7, 3.8, $3.12,4.12$ e 4.13 .

A percepção "tradicional" que os examinados possuem dos crimes "a partir de sua própria cultura" deve ser buscada nos relatos míticos e nas explicações filosóficas que fundamentam a consciência moral e religiosa do grupo. Nessas fontes orais fala-se de uma geração que careceu de entendimento e se inspirou na má ciência, sendo vítima de uma fúria extrema. Por se ter deixado dominar pela ira, esta geração foi convertida em rãs e escaravelhos. Deixar-se dominar pela irracionalidade desses seres supostamente inferiores pode ser uma referência às tendências destruidoras na própria natureza humana. Efetivamente, tanto os grupos Kaiowa como os Guarani colocam, em última instância, a cólera como causa da violência e dos males que conhecem. Conforme o mito de origem desses grupos, "Nosso Pai" abandonou a "Nossa Mãe", por causa da cólera e da indignação que Ihe acometeram (GOMEZ-PERASO, 1976, p. 44-45).

Um personagem mítico kaiowa, Yryvera, em uma festa batera em um parente seu, que adoeceu e morreu. A alma do defunto teria se queixado a "Nosso Pai" que, muito irado, se propôs a destruir o delinquente. Em outros relatos, "Nossa Mãe" aparece acusando "Nosso Pai" de ter-se embebedado em uma festa e de, irado, ter causado a primeira morte na terra (MELIÀ, 1976, p.235). Já nos episódios protagonizados pelos "Nossos Irmãos", na tradição kaiowa, a ira acomete a "Nossa Mãe" e o "Nosso Irmão Maior". Ela, encolerizada pela impertinência de sua criança, teria então batido na mão do filho. Este, enfezado e muito irado abandonou sua mãe, quem desatinada vai parar na casa dos jaguares, que a assassinam (CHAMORRO, 1995, p.95-96).

Nessas histórias observa-se que a ira tem como desenlace o abandono e, uma das suas maiores consequências, o homicídio. As diversas formas de violência são recriminadas pela consciência moral do grupo. Esses episódios buscam, dessa forma, conscientizar as pessoas das tendências destruidoras inscritas em sua natureza e adverti-las sobre as tragédias que a ira pode acarretar em suas vidas. 
4.18. OS DELEGADOS RESPONSÁVEIS PELO INQUÉRITO POLICIAL POSSUÍAM AO TEMPO DAS OITIVAS COM OS INDÍGENAS DE PASSO PIRAJU E EXAMINADOS, AS COMPETÊNCIAS COMUNICATIVAS (GRAMATICAL, LINGUÍSTICA, DISCURSIVA E INTERACIONAL) NECESSÁRIAS PARA REALIZAR AS ENTREVISTAS SEM QUE OS INQUIRIDOS SE SENTISSEM CONFUSOS OU COAGIDOS A RESPONDER?

Não. Na tarde do dia 08/05/2008, o perito da equipe esteve ainda com a delegada Magali Leite Cordeiro Pascoal, na sede local da Delegacia de Defesa da Mulher, em Dourados, quem explicou não saber a língua guarani, tampouco demonstrou entender o idioma cultural dos réus.

Conforme explicado na resposta ao quesito $n^{\circ}$. 2.2, formulado pelo Juízo, os sete primeiros réus presos disseram que foram coagidos a responder as perguntas que lhes foram feitas durante a tomada dos primeiros depoimentos. Afirmaram de maneira peremptória que foram torturados na sede do DOF em Dourados, inclusive por meio de eletrochoque.

4.19. QUE FATOS ANTERIORES AO CONFRONTO COM OS POLICIAIS PODERIAM TER LEVADO OS INDÍGENAS A CONFUNDIREM POLICIAIS COM POTENCIAIS AGRESSORES?

Conforme consta na resposta formulada ao quesito do Juízo de $\mathrm{n}^{0}$. 2.2 , dentre os "fatos anteriores ao confronto com os policiais" que "poderiam ter levado os indígenas a confundirem policiais com potenciais agressores" estão as investidas que Beline Nascimento Chaves, filho de Esmalte Barbosa Chaves, e seus aliados, ou de pessoas a ele ligadas, teriam feito amiúde contra a comunidade de Passo Piraju, sobretudo nos finais de semana, entre o final da tarde e a noite.

\subsection{DESCONHECEDORA DAS TEORIAS ANTROPOLÓGICAS} CONTEMPORÂNEAS, A SOCIEDADE ENVOLVENTE TEM ENFATIZADO QUE OS ÍNDIOS DE PASSO PIRAJU E RÉUS NO PRESENTE PROCESSO SÃO INTEGRADOS. EXPLICITAR PARA OS OPERADORES DE DIREITO AS FALHAS DOS PRESSUPOSTOS EPISTEMOLÓGICOS DAS TEORIAS QUE APONTAM PARA A DITA “INTEGRAÇÃO".

A afirmativa de que "os índios de Passo Piraju e réus no presente processo são integrados", comumente dita por indivíduos da sociedade envolvente, e por vezes veiculadas por setores da imprensa local, está situada no campo do senso comum e não condiz com os resultados do presente laudo antropológico, conforme explicado nas respostas formuladas aos quesitos de $n^{\circ} .2 .3,2.4,3.1,3.14,4.1,4.12$ e 4.13 .

Em que pese saber das dificuldades que os operadores do direito possam ter em se manter atualizados a respeito das teorias antropológicas contemporâneas, tem-se a compreensão de que os antropólogos também enfrentam semelhantes dificuldades em relação às teorias em voga no mundo do direito. Não obstante, entende-se que poderá haver uma grande falha caso a legislação 
brasileira venha a ser interpretada à luz das antigas - e ultrapassadas - teorias da assimilação, integração ou aculturação dos índios. A falha capital seria desconsiderar que, embora as teorias assimilacionistas estejam presentes na Lei $n^{\circ}$. $6.001 / 1973$, salvo melhor juízo elas foram superadas por teorias relativistas presentes em instrumentos superiores como a Carta Constitucional (1988), a Convenção OIT nº. 169 (1989) e a Declaração Universal dos Direitos dos Povos Indígenas (2007).

Das teorias antropológicas contemporâneas, uma das mais importantes - senão a principal - é a teoria da etnicidade. Trata-se de uma teoria mundialmente recorrida para o reconhecimento de identidades étnicas e, consequentemente, dos direitos de minorias como as indígenas e quilombolas. Foi mais bem desenvolvida a partir do final da década de 1960 pelo antropólogo norueguês Fredrik Barth, nascido em 1928 e ainda em atividade (Vide BARTH, 1969, 1976, 1998; PACHECO DE OLIVEIRA, 1999). Em linhas gerais, resume-se na percepção de que a identidade étnica de grupos humanos é definida de dentro para fora, quer dizer, que a etnicidade é um fenômeno sociocultural que se processa no interior dos grupos étnicos, como é no caso dos Guarani e Kaiowa, para a exterioridade, a exemplo da sociedade nacional. Via de regra esta situação assemelha-se a um jogo de espelhos em que um grupo se percebe diferente diante do outro pela contrastividade que se dá em situações de contatos interétnicos.

4.21. PRESTEM OS SENHORES PERITOS TODAS AS INFORMAÇÕES QUE ENTENDEREM NECESSÁRIAS À SOLUÇÃO DO PRESENTE INCIDENTE, DESCREVENDO EM CONCLUSÃO CIRCUNSTANCIADA O GRAU DE IMPUTABILIDADE DOS RÉUS, BEM COMO O NÍVEL DE CAPACIDADE DE ENTENDIMENTO DO CARÁTER DELITUOSO DA CONDUTA BEM COMO A FORMA DE AGIR COLETIVO NA DEFESA DE SEU POVO.

Ver as respostas elaboradas aos quesitos formulados pelo Juízo e Mistério Público Federal.

\section{Quesitos do assistente de acusação}

5.1. AS "TATUAGENS" ENCONTRADAS EM ALGUNS DOS ÍNDIOS, RÉUS NESTE PROCESSO, FAZEM PARTE, DE SEUS USOS E COSTUMES?

Sim. Para um melhor entendimento desta afirmativa faz-se imprescindível analisar as respostas elaboradas aos quesitos apresentados anteriormente, principalmente os formulados pelo Juízo e pelo Ministério Público Federal.

Embora os peritos não tenham examinado minuciosamente os corpos dos acusados para averiguar a existência ou não de tatuagens ou dermopigmentações, vale lembrar que pinturas corporais são tradicionais para a maioria dos povos indígenas no Brasil, conforme de percebe na Figura 1, incluída na resposta ao quesito 2.2 formulado pelo Juízo. A 
Espaço Ameríndio

diferença maior entre uma pintura corporal e uma tatuagem é que a primeira é temporária e a segunda é permanente, conforme o conceito de tatuagem disponível na enciclopédia Wikipédia:
A tatuagem (também referida como tattoo na sua forma em inglês) ou dermopigmentação ("dermo" = pele; "pigmentação" ato de pigmentar, ou colorir) é uma das formas de modificação do corpo mais conhecidas e cultuadas do mundo. Trata-se de um desenho permanente feito na pele humana, é tecnicamente uma aplicação subcutânea obtida através de introdução de pigmentos por agulhas, um procedimento que durante muitos séculos foi irreversível. A motivação para os colecionadores dessa arte é ser uma obra de valor eterno ${ }^{27}$.

Hoje em dia é comum constatar jovens indígenas com tatuagens feitas pelo corpo. Esta é uma situação relativamente comum na Reserva Indígena de Dourados, onde estão as aldeias Bororó e Jaguapiru, e menos na Reversa Indígena Panambizinho, apenas para exemplificar. Em geral são demopigmentações reelaboradas e ressignificadas dentro de uma lógica cultural própria. Servem como marcas de distintividade étnica para a sociedade nacional e como marcas de distintividade pessoal entre diferentes gerações de indígenas. Comumente são tatuados corações, trevos de quatro folhas, frases do tipo "Te amo S" (no caso observado a letra "S" correspondia a primeira letra do nome Sílvia) e assim por diante.

Geralmente as tatuagens são feitas com o uso de agulhas de costurar ou, o que é menos frequente, com espinhos de bocaiúva ou macaúba (Acrocomia aculeata). Esses materiais perfurantes são envolvidos com linha de costura e mergulhados em tinta azul ou preta. Depois de umedecidos em tinta são usados para perfurar a pele, marcando-a com desenhos diversos.

No senso comum da sociedade nacional tatuagens desse tipo podem ser vistas como símbolos de aculturação, assimilação ou integração dos povos nativos à comunhão nacional, o que definitivamente não possui base antropológica alguma. Também podem ser vistas como marcas de periculosidade, o que igualmente não corresponde à realidade.

No caso dos réus Ezequiel Valensuela, Lindomar Brites de Oliveira e Paulino Lopes, conforme explicado na resposta dada ao quesito de $\mathrm{n}^{\circ}$. 2.2, formulado pelo Juízo, eles afirmam que um agente carcerário foi o responsável por algumas das tatuagens estampadas em seus corpos, conforme constam nas fotografias apresentadas na sequência.

\footnotetext{
${ }^{27}$ Wikipédia - A Enciclopédia Livre. Disponível em: $<$ http://pt.wikipedia.org/wiki/Tatuagem $>$. Acessado em: 25 mai. 2008.
} 
Espaço Ameríndio

Figura 9: Tatuagem feita na PHAC e estampada no peito esquerdo de Lindomar Brites de Oliveira.

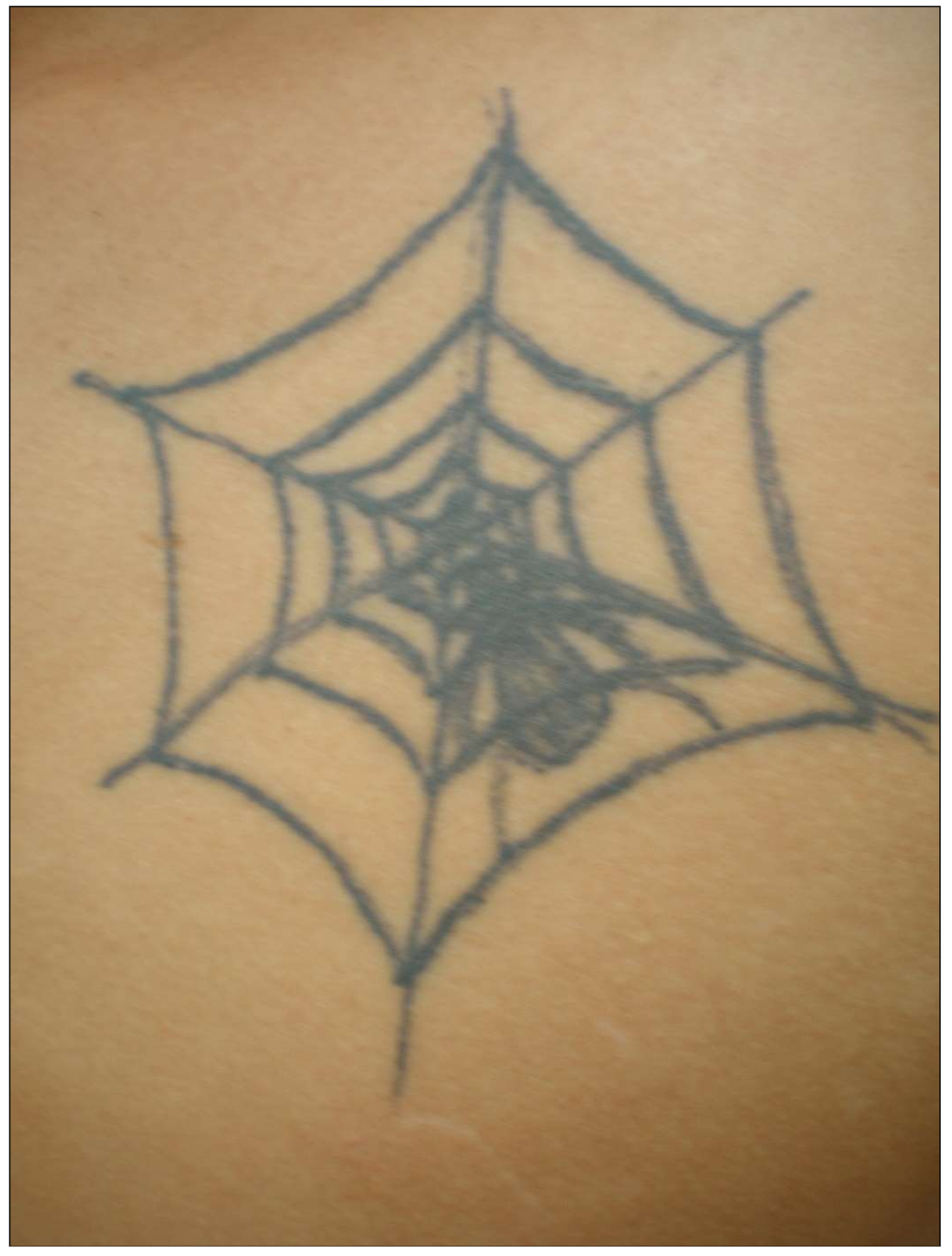


Espaço Ameríndio

Figura 10: Tatuagens feitas na PHAC e estampadas no braço direito de Paulino Lopes. Um dos desenhos lembra a imagem ocidental da morte.

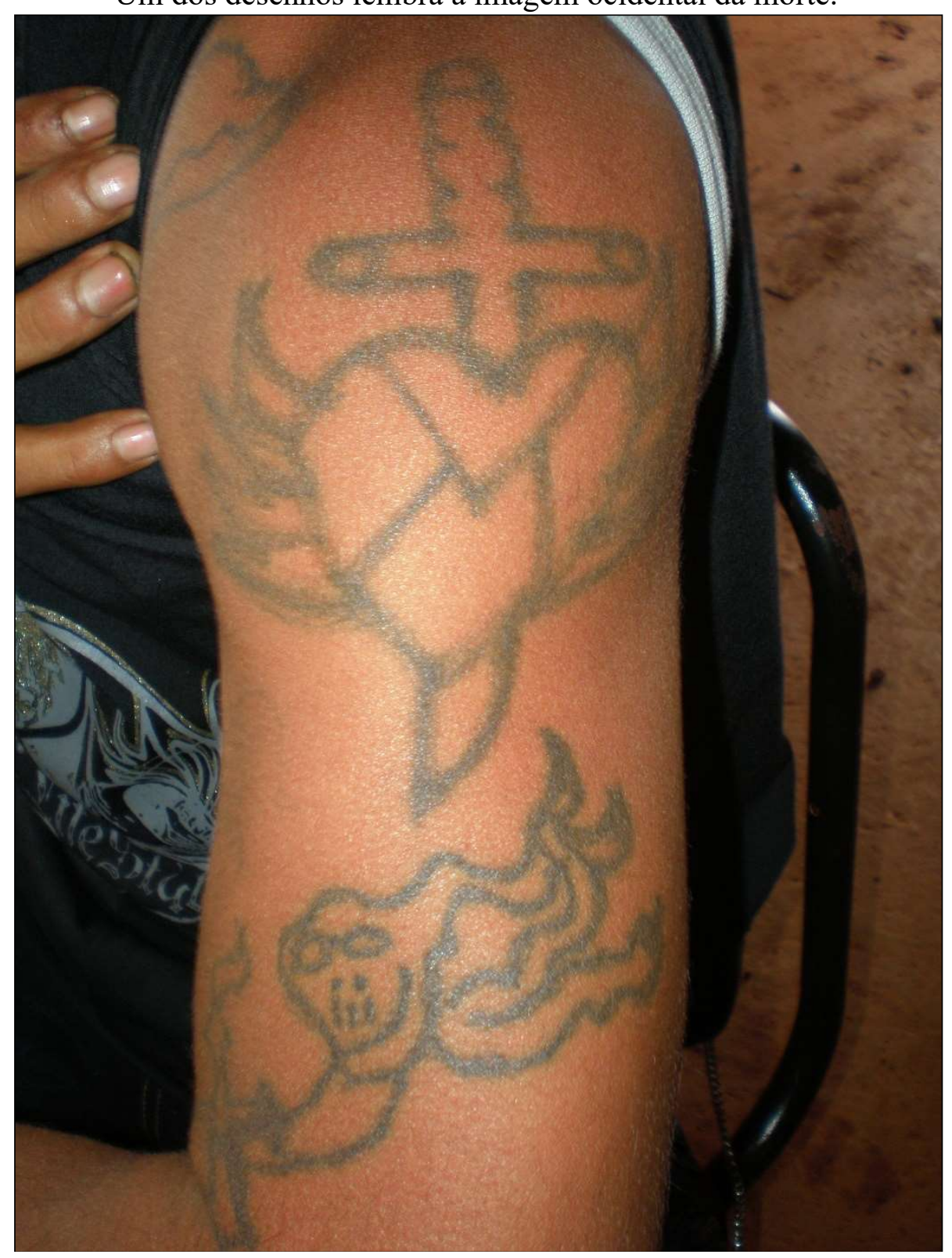


Figura 11: Tatuagens feitas na PHAC e estampadas no braço direito de Ezequiel Valensuela. Alguns desenhos lembram dragões.

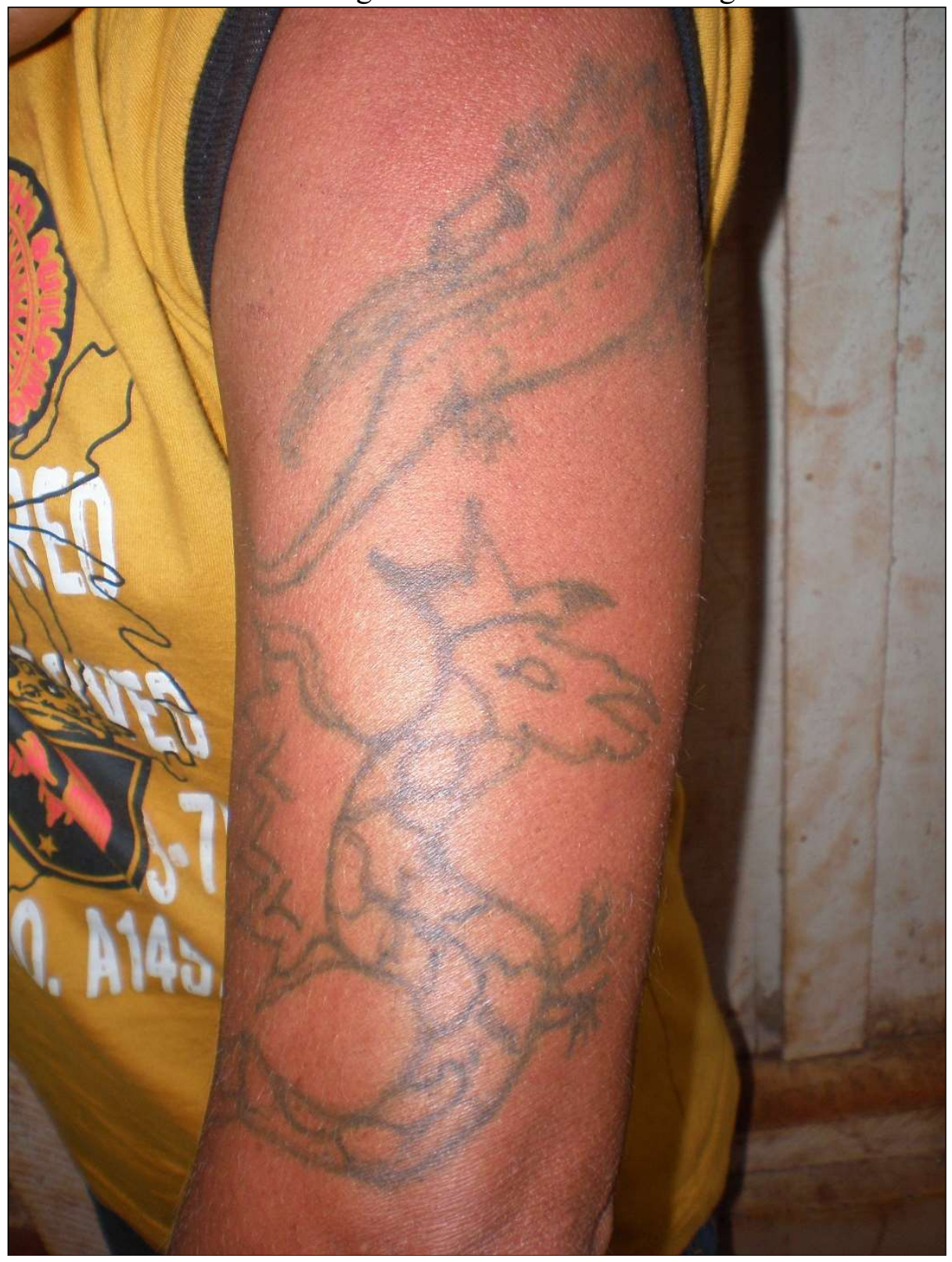

Portanto, segundo os referidos réus, todas as tatuagens retro apresentadas foram feitas sem sua autorização e como parte da violência proferida contra eles por agentes carcerários na PHAC.

5.2. AS VESTIMENTAS QUE ORA OS ÍNDIOS, RÉUS NESTE PROCESSO, USAM, FAZ PARTE DE SUA CULTURA ORIGINAL?

Sim. Conforme respostas dadas aos quesitos anteriores, como o de $\mathrm{n}^{\circ}$. 5.1, vestimentas fazem parte da cultura dos índios desde que o termo "original" não tenha sido incluído neste quesito para se referir aos tempos pré-colombianos.

Se os índios usam vestimentas iguais às usadas pelos não-índios, sobretudo quando se fazem presentes no meio urbano de cidades como 
Espaço Ameríndio

Dourados, percebe-se aí o entendimento de uma regra social em vigor na sociedade nacional. Caso andassem nus e pintados pelas ruas das cidades sul-mato-grossenses, certamente causariam grande estranhamento por parte da população não-indígena e, consequentemente, situações conflituosas.

5.3. OS ÍNDIOS, RÉUS NESTE PROCESSO, JÁ ASSIMILARAM USOS E COSTUMES DOS CHAMADOS "HOMENS BRANCOS"? SE POSITIVO, DE QUE FORMA?

Uma resposta a este questionamento consta nas respostas apresentadas aos quesitos formulados pelo Juízo, Ministério Público Federal e AGU/PGF/FUNAI. 
Espaço Ameríndio

\section{Referências bibliográficas}

\section{Fontes primárias}

ACUSADO de matar pastor é condenado a 14 anos de prisão. Matéria divulgada em 29/08/2007 no sítio eletrônico Agora MS. Disponível em: $<$ http://www.agorams.com.br/index.php?ver=ler\&id=109632 $>$. Acesso em: 27 abr. 2008.

BUENO, Thaísa. 2004. Fazendeiro contrata segurança para se proteger de índios. Disponível em: $<$ http://www.midiamax.com/view.php?mat id=83823\#>. Acesso em: 03 jun. 2008.

CASTRO, Nakienka; FILHO, Hélio. 2006. Zeca diz que índios premeditaram emboscada a policiais civis. Disponível em: $<\underline{\text { http://www.capitaldopantanal.com.br/index.php?sPagina }=\text { cpt002 noticia\&iNoticia }=47}$ 55\&sCanal>. Acesso em: 24 mai. 2008.

DECLARAÇÃO das Nações Unidas sobre os Direitos dos Povos Indígenas (2007). 2008. Brasília: Secretaria Especial dos Direitos Humanos.

DOURADO, Jean Cléber S.; VIANA, Eraldo F. 2006. Laudo Pericial nº 11.710/DO. Dourados: Coordenadoria-Geral de Perícias, Instituto de Criminalística "Hercílio Macellaro", Núcleo Regional de Dourados, 15p.

FRIAS, Silvia. 2004. Índios desocuparam fazenda Campo Belo, afirma PF.

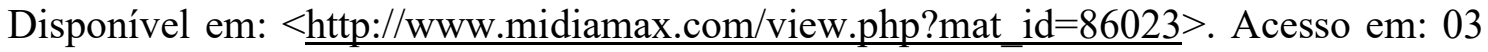
jun. 2008.

FUNAI e PF fazem varredura em aldeias de Dourados. Artigo divulgado em 16/07/2004. Disponível em: <http://www.brasiloeste.com.br/noticia/1068/>. Acesso em: 19 jun. 2008.

INDÍGENAS são atuados em fragrante por matarem dois policiais em Dourados. Matéria divulgada em 03/04/2006 no sítio eletrônico Capital do Pantanal. Disponível em:

$<$ http://www.capitaldopantanal.com.br/index.php?sPagina $=$ cpt002 noticia\&iNoticia $=47$

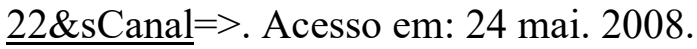

ÍNDIOS acusados de matar policiais civis são soltos. Matéria divulgada pela redação do jornal virtual Capital do Pantanal. Disponível em: $<$ http://www.capitaldopantanal.com.br/index.php?sPagina $=$ cpt002 noticia\&iNoticia $=22$

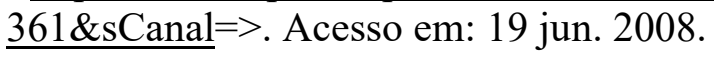

LIMA, Marcos Homero F. 2005. Relatório de visita ao Hospital Evangélico de Dourados. Dourados: Ministério Público Federal, 3p. Data: 17/06/2005. (não publicado) 
Espaço Ameríndio

MAGALHÃES, Edvard D. (Org.). 2003. Legislação Indigenista Brasileira e Normas Correlatas. $2^{\mathrm{a}}$ ed. revista e atualizada. Brasília: CGDOC/FUNAI.

NAVARRO, Cristiano. 2007. Ministério da Justiça mostra primeiros dados sobre indígenas presos. Disponível em: $<$ http://www.cimi.org.br/dev.php?system $=$ news\&action=imprimir\&id=2700\&eid=235> . Acesso em: 27 mai. 2008.

REPRESENTANTE da OAB-MS critica segregação de índios em penitenciárias. Matéria divulgada em 09/05/2008 no sítio eletrônico da OAB Mato Grosso do Sul. Disponível em: $\quad<$ http://www.oabms.org.br/noticias/lernoticia.php?noti_id=4541 $>$. Acesso em: 27 mai. 2008.

ZECA do PT é denunciado pelo MPF por calúnia e difamação. Matéria divulgada em 06/08/2007 no sítio eletrônico Agora MS. Disponível em: $<$ http://www.agorams.com.br/index.php?ver=ler\&id=107784 $>$. Acesso em: 27 mai. 2008.

\section{Fontes secundárias}

ABA - Associação Brasileira de Antropologia. Convenção para a grafia dos nomes tribais. Revista de Antropologia, São Paulo, 2 (2), 1954.

ADRIANA DA SILVA, M. O movimento dos Guarani e Kaiowa de reocupação e recuperação de seus territórios em Mato Grosso do Sul e a participação do Conselho Indigenista Missionário (CIMI), 1978-2001. Dissertação (Mestrado em História) Universidade Federal de Mato Grosso do Sul, Dourados, 2005

BARTH, F. (Ed.). Ethnic groups and boundaries: the social organization of culture difference. Bergen/Oslo: Universitetsforlaget; London: George Allen \& Unwin, 1969.

BARTH, F. (Comp.). Los grupos étnicos y sus fronteras. La organización social de las diferencias culturales. México: FEC, 1976.

BARTH, F. Grupos étnicos e suas fronteiras. In: POUTIGNAT, P. \& STREIFFFENART, J. Teorias da etnicidade. Trad. de Élcio Fernandes. São Paulo: Editora UNESP, p.185-227, 1998 [1969].

BECKER, H. S. Métodos de pesquisa em ciências sociais. Tradução de M. Estevão \& R. Aguiar. São Paulo: Hucitec, 1993.

BECKHAUSEN, M. Questões de cidadania e o diálogo entre o mundo jurídico e a antropologia. As consequências do reconhecimento da diversidade cultural. s.l., s.e., 18 p, 2008. (não publicado)

BRAND, A J. O confinamento e seu impacto sobre Pãi/Kaiowa. Dissertação (Mestrado em História) - Pontifícia Universidade Católica do Rio Grande do Sul, Porto Alegre, 1993. 
Espaço Ameríndio

BRAND, A. J. O impacto da perda da terra sobre a tradição Kaiowa/Guarani: os difíceis caminhos da palavra. Tese (Doutorado em História) - Pontifícia Universidade Católica do Rio Grande do Sul, Porto Alegre, 1997.

DÁVALOS, P. Movimientos indígenas en América Latina: el derecho a la palabra. In: DÁVAlOS, P. (Coord.). Pueblos indígenas, estado y democracia. Buenos Aires: Clacso, p.17-33, 2005.

DEBERT, G. G. Problemas relativos à utilização de histórias de vida e história oral. In: CARDOSO, Ruth (Org.). Aventura antropológica. Rio de Janeiro: Paz e Terra, p.141$156,1983$.

CADOGAN, L. Como interpretan los Chiripá (Avá Guaraní) la danza ritual. Revista de Antropologia, São Paulo, 7: 65-99, 1959.

CARDOSO DE OLIVEIRA, R. Pesquisas em versus pesquisas com seres humanos. In: VÍCTORA, C. et al. (Org.). Antropologia e ética: o debate atual no Brasil. Rio de Janeiro: Editora UFF, p.33-44, 2004.

CARDOSO DE OLIVEIRA, R. (Org.). A antropologia de Rivers. Tradução de G. Cardoso de Oliveira \& S. B. Ramagem. Campinas: Editora Unicamp, 1991.

CARDOSO DE OLIVEIRA, R.. O trabalho do antropólogo. $2^{\mathrm{a}}$ ed. São Paulo: Editora Unesp, 2000

CHAMORRO, G. Kurusu ñe'ëngatu: palabras que la historia no podría olvidar. Asunción: Centro de Estudios Antropológicos de La Universidad Católica "Nuestra Señora de la Asunción", 1995.

CHASE-SARDI, M. El precio de la sangre, tuguy ñeẽ repy; estudio de la cultura y el control social entre los Avá-Guaraní. Asunción: CEADUC, 1992.

CHASE-SARDI, M. et al. Situación sociocultural, económica, jurídico-política actual de las comunidades indígenas en el Paraguay. Asunción: CIPSEP, 1990.

CIMI et al. (Org.). Conflitos de direitos sobre as terras Guarani Kaiowa no Estado do Mato Grosso do Sul. São Paulo: Palas Athena, 2000.

CORRÊA, V. B. Coronéis e bandidos em Mato Grosso (1889-1943). Campo Grande: UFMS, 1995.

MACEDO, C.; FLORES, A. (Coord.). Situação dos detentos indígenas do estado de Mato Grosso do Sul. Brasília: CTI, 2008.

EREMITES DE OLIVEIRA, J. Cultura material e identidade étnica na arqueologia brasileira: um estudo por ocasião da discussão sobre a tradicionalidade da ocupação Kaiowa da Terra Indígena Sucuri’y. Cultura e sociedade, Goiânia, 10 (1): 95-114, 2007.

EREMITES DE OLIVEIRA, J; PEREIRA, L. M. Perícia antropológica, arqueológica e histórica da área reivindicada pelos Terena para a ampliação dos limites da Terra 
Espaço Ameríndio

Indígena Buriti, municípios de Sidrolândia e Dois Irmãos do Buriti, Mato Grosso do Sul, Brasil. Autos n ${ }^{\circ}$. 2001.60.00.003866-3, $3^{\text {a }}$ Vara da $1^{\text {a }}$ Subseção Judiciária de Campo Grande, 2003.

PEREIRA, L. M.; EREMITES DE OLIVEIRA, J. Perícia antropológica e histórica da área identificada pela FUNAI como sendo a Terra Indígena Ñande Ru Marangatu. Autos $n^{\circ}$. 2001.60.02.001924-8, $1^{\text {a }}$ Vara da $5^{\text {a }}$ Subseção Judiciária de Ponta Porã, 2007.

FERNANDES DA SILVA, J. A. Os Kaiowa e a ideologia dos projetos econômicos. Dissertação (Mestrado em Antropologia) - Universidade Estadual de Campinas, Campinas, 1982.

GOMEZ-PERASO, J. A. Contexto socioeconómico del indio en el Paraguay oriental. Revista Paraguaya de Sociología, Asunción, 13 (37): 37-48, 1976.

GRÜNBERG, F. P.; AOKI, C. Informações básicas sobre temas fundiários para os Kaiowa e Guarani no Mato Grosso do Sul. Ponta Porã: PKG/CTI, 2004.

GUASCH, A.; ORTIZ, D. Diccionario Castellano-Guaraní y Guaraní-Castellano. 13 ${ }^{\text {a }}$ ed. Asunción: CEPAG, 2001.

GUDSCHINSKY, S. C. Fragmentos de Ofaié: a descrição de uma língua extinta. Tradução de Miriam Lemle. Brasília: Summer Institute of Linguistics. (Série Linguística, 3), 1974.

IBANHES, B. Silvino Jacques: o último dos bandoleiros, o mito gaúcho sul-matogrossense. $3^{\text {a }}$ ed. Campo Grande: Editora UFMS, 1997.

LANDA, B. dos S. Os Ñandeva/Guarani e o uso do espaço na Terra Indígena Porto Lindo/Jakarey, município de Japorã/MS. Tese (Doutorado em História/Arqueologia) - Pontifícia Universidade Católica do Rio Grande do Sul, Porto Alegre, 2v, 2005.

MACIEL, N. A. História dos Kaiowa da aldeia Panambizinho: da década de 1920 aos dias atuais. Dissertação (Mestrado em História) - Universidade Federal de Mato Grosso do Sul, Dourados, 2005.

MAHER, T. de J. M. Ser professor sendo índio: questões de língua(gem) e identidade. Tese (Doutorado em Linguística) - Universidade Estadual de Campinas, Campinas, 1996.

MALINOWSKI, B. Argonautas do Pacífico ocidental: um relato do empreendimento e da aventura dos nativos nos arquipélagos da Nova Guiné Melanésia. Tradução de A. P. Carr \& L. A. C. Mendonça. $3^{a}$ ed. São Paulo: Abril Cultural, 1984 [1922].

MAUSS, M. Manuel d'etnographie. Paris : Édition Payot, 1967.

MAUSS, M. Manual de Etnografia. Prefácio de Denise Paulme. Tradução de J. Freitas e Silva. Lisboa: Publicações Dom Quixote, 1993.

MELIÀ, B. et al. Etnografía guaraní del Paraguay contemporáneo: los Paĩ-Tavyterã. Suplemento Antropológico, Asunción, 11 (1-2) :151-295, 1976. 
MELIÀ, B. El Guaraní conquistado y reducido: ensayos en etnohistoria. $2^{\mathrm{a}}$ ed. Asunción: CEADUC, p. 106, 1988.

MELIÁ, B. Los Paĩ-Tavyterã del Amambay 15 años después. 500 años del Encuentro de dos Mundos. Barcelona: s.e., p.1-12, 1990.

MELIÀ, B. El pueblo Guaraní: unidad y fragmentos. Tellus, Campo Grande, 4 (6): 151 $162,2004$.

MONTEIRO, M. E. B. (Org.). Levantamento histórico sobre os índios Guarani/Kaiowa. Prefácio de Rubem F. Thomaz de Almeida. Rio de Janeiro: Museu do Índio, 2003.

MOREIRA DA SILVA, L. A legitimidade do processo de retomada das terras tradicionais pelos índios Kaiowa e Ñandeva em Mato Grosso do Sul. Dissertação (Mestrado em Direito) - Universidade de Brasília /Centro Universitário da Grande Dourados, 2002.

MURA, F. À procura do "bom viver": território, tradição de conhecimento e ecologia doméstica entre os Kaiowa. Tese (Doutorado em Antropologia Social) Museu Nacional da Universidade Federal do Rio de Janeiro, Rio de Janeiro, 2006.

NIMUENDAJU, C. As lendas da criação e destruição do mundo como fundamentos da religião dos Apapocúva-Guarani. Tradução de Charlote Emmerich \& Eduardo B. Viveiros de Castro. São Paulo: Hucitec/Edusp, 1987 [1914].

NIMUENDAJU, C. Etnografia e indigenismo: sobre os Kaingang, os Ofaié-Xavante e os índios do Pará. Campinas: Editora Unicamp, 1993 [1920].

PACHECO DE OLIVEIRA, J. Ensaios em antropologia histórica. Prefácio de Roberto C. de Oliveira. Rio de Janeiro: Editora UFRJ, 1999.

PEREIRA, L. M. Parentesco e organização social kaiowa. Dissertação (Mestrado em Antropologia) Universidade Estadual de Campinas, Campinas, 1999.

PEREIRA, L. M. No mundo dos parentes: a socialização das crianças adotadas entre os Kaiowa. In: LOPES DA SILVA, Aracy et al. (Org.). Crianças Indígenas: ensaios antropológicos. São Paulo: Global, p.168-187, 2002.

PEREIRA, L. M. O movimento étnico-social pela demarcação das terras guarani em MS. Tellus, Campo Grande, 3 (4): 137-145, 2003.

PEREIRA, L. M. Imagens Kaiowa do sistema social e seu entorno. Tese (Doutorado em Ciências/Antropologia) - Universidade de São Paulo, São Paulo, 2004a.

PEREIRA, L. M. O pentecostalismo Kaiowa: uma aproximação dos aspectos sociocosmológicos e históricos. In: WRIGHT, Robin M. (Org.). Transformando os deuses: igrejas evangélicas, pentecostais e neopentecostais entre os povos indígenas no Brasil. Campinas: Editora Unicamp, p.267-301, 2004b. 
PEREIRA, L. M. Assentamentos e formas organizacionais dos Kaiowa atuais: o caso dos “índios de Corredor”. Tellus, Campo Grande, 6 (10): 69-81, 2006.

PEREIRA, L. M. Mobilidade e formas de assentamento entre os Kaiowa atuais. História \& Reflexão, Dourados, 2: 3-15, 2007.

PEREIRA, L, M.; EREMITES DE OLIVEIRA, J. 2007. Perícia antropológica e histórica da área identificada pela FUNAI como sendo a Terra Indígena Nande Ru Marangatu. Autos $n^{\circ}$. 2001.60.02.001924-8, $1^{\text {a }}$ Vara da $5^{\text {a }}$ Subseção Judiciária de Ponta Porã.

SANTOS DUTRA, C. A. dos. Ofaié, morte e vida de um povo. Campo Grande: Instituto Histórico e Geográfico de Mato Grosso do Sul, 1996.

SANTOS DUTRA, C. A. dos. O território Ofaié pelos caminhos da história: reencontro e trajetória de um povo. Dissertação (Mestrado em História) - Universidade Federal de Mato Grosso do Sul, Dourados, 2004.

SANTOS FILHO, R. L. dos. Índios e imputabilidade penal. Bauru: s/ed., 10p., s/d. (não publicado)

SANTOS FILHO, R. L. dos. Apuração e julgamento de crimes praticados por índios. Bauru: s/ed., 5 p., 2006. (não publicado)

SCHADEN, E. Aspectos fundamentais da cultura guarani. $3^{\text {a }}$ ed. São Paulo: Edusp, 1974 [1954].

STEFANES PACHECO, R. A. Mobilizações guarani Kaiowa e Nandeva e a (re) construção de territórios (1978-2003): novas perspectivas para o Direito Indígena. Dissertação (Mestrado em História) - Universidade Federal de Mato Grosso do Sul, Dourados, 2004.

THOMAZ DE ALMEIDA, R. F. Do desenvolvimento comunitário à mobilização política. O Projeto Kaiowa-Ñandeva como experiência antropológica. Apresentação de João Pacheco de Oliveira. Rio de Janeiro: Contra Capa, 2001.

THOMAZ DE ALMEIDA, R. F. Relatório de visita ao acampamento de Porto Cambira, Dourados (MS), onde estão os grupos macrofamiliares Guarani-Kaiowa que reivindicam antigo tekoha denominado Passo Piraju. Rio de Janeiro: s.e., 2004. (não publicado)

\section{Sítios eletrônicos consultados}

http://www.agorams.com.br

http://www.brasiloeste.com.br http://www.capitaldopantanal.com.br

http://www.diarioms.com.br

http://www.cimi.org.br 
Espaço Ameríndio

http://www.google.com.br

http://www.midiamax.com

http://www.oabms.org.br

http://www.oprogresso.com.br

http://www.portalms.com.br

http://pt.wikipedia.org 
Espaço Ameríndio

\section{Anexos}

LIMA, Marcos Homero F. 2005. Relatório de visita ao Hospital Evangélico de Dourados. Dourados, Ministério Público Federal, 3p. Data: 17/06/2005. 


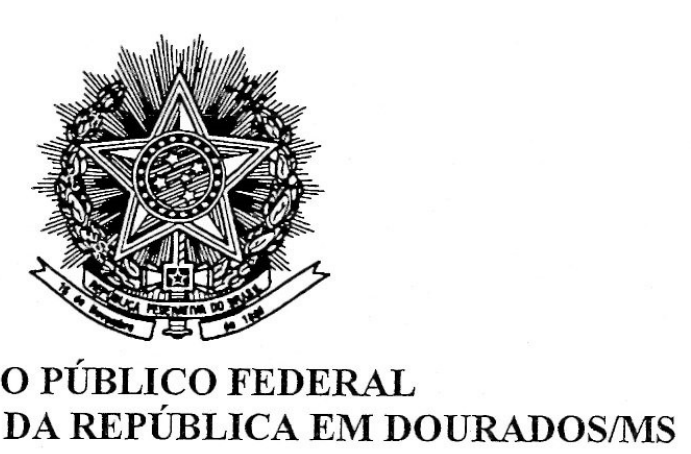

RELATÓRIO DE VISITA AO HOSPITAL EVANGÉLICO DE DOURADOS

Por solicitação do Procurador da República em Dourados -MS, Charles Stevan da Mota Pessoa, dirigi-me, na manhã de hoje, 17 de junho de 2005, ao Hospital Evangélico, nesta Cidade. O motivo da diligência fora perquirir junto ao índio da etnia Kaoiwa acerca das circunstâncias que envolveram o atropelamento de que foi vitimado, no início da noite de ontem, 16.06.2005, na estrada de barro que une Dourados à Região de Porto Cambira, onde se localiza a Terra Indígena Passo Piraju.

Ao chegar ao hospital encontrei-me com a vítima, o SR. SÉRGIO ARAÚJO, a quem me foi apresentado por um servidor do hospital. O SR. SÉRGIO ARAÚJO estava sentado numa cadeira com o pé direito engessado. $O$ indígena acidentado não é bem-versado na língua portuguesa, tanto que encontrei dificuldade em entendê-lo plenamente. Conversamos por cerca de 20 minutos e tudo o que pude depreender da conversa era que ele era residente em Dourados, numa localidade conhecida como "Mudas MS". O acidente acontecera quando SR. SÉRGIO ARÁÚIO juntamente com o seu cunhado se deslocavam de Dourados para Porto Cambira. Os dois vinham na mesma bicicleta quando ocorreu o acidente, um veículo teria tocado o ciclista e seu carona e ambos tombaram ao chão. O SR. SÉRGIO ARAÚJO foi menos afortunado indo cair num buraco, ao que tudo indica uma vala, onde machucou o pé. Dada a minha inabilidade em questionar a vítima, achei por bem buscar ajuda. Pedi que o Coordenador de Políticas Públicas da Prefeitura de Dourados, o Sr. Anastácio Peralta, viesse em meu auxílio, uma vez que este

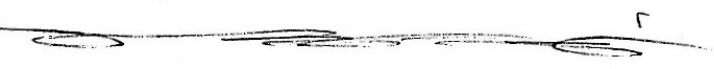




\section{MINISTÉRIO PÚBLICO FEDERAL PROCURADORIA DA REPÚBLICA EM DOURADOS/MS}

servidor municipal é indígena da mesma etnia do acidentado e, portanto, fluente em sua língua.

Antes do Sr. Anastácio Peralta ir ter-se com o SR. SÉRGIO ARAÚJO, expliquei-lhe, brevemente, quais eram as minhas questões. Queria que confirmasse a minha compreensão da fala com o enfermo. Ademais, precisava saber detalhes sobre o acidente em si, se ele havia visto o carro que o abalroou, se conhecia o dono do mesmo.

Apresentei o Sr. Peralta ao paciente. Os dois começaram a conversar em Guarani e, do pouco que pude depreender da conversa, ouvi o SR. SÉRGIO ARAÚJO proferindo as palavras "D20 - Moronti", que traduzido para o português significa "D20 branca".

A versão que me foi traduzida pelo Sr. Anastácio Peralta foi a seguinte:

O Sr. SR. SÉRGIO ARAÚJO estava em Dourados, na Sede do Município, onde se encontrou com o seu cunhado, o Sr Ventura. Este último o convidou para ir até a sua residência em Passo Piraju, em Porto Cambira. Ambos seguiram numa única bicicleta, o cunhado à frente, pedalando, e o SR. SÉRGIO ARAÚJO, atrás, na qualidade de carona. Saíram de Dourados, já próximo ao anoitecer. Quando já haviam deixado a pavimentação asfáltica e já se encontravam na estrada de terra, uma caminhonete de cor branca, a que denominou de "D20", vinda por trás, "raspou" os dois que vinham na bicicleta, sendo que, apenas o carona veio a se machucar e, pelo que deixou transparecer, a lesão no pé resultou da caída ao chão e não da colisão (ou "raspada"). 


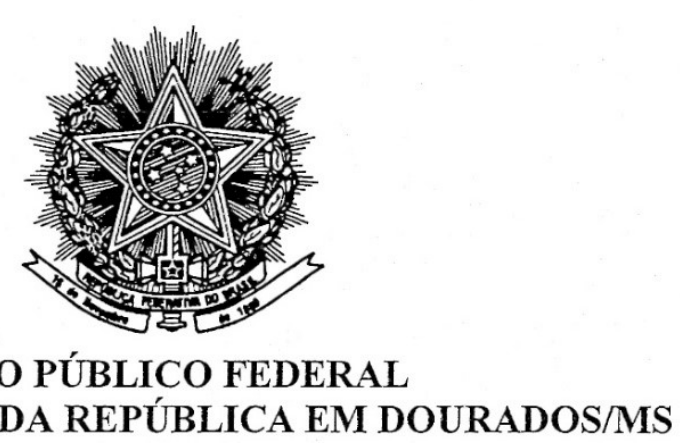

\section{PROCURADORIA DA REPÚBLICA EM DOURADOS/MS}

O carro, o SR. SÉRGIO ARAÚJO, não o viu mais. Tendo se refeito, ambos se puseram na estrada. O cunhado à frente, pedalando, e o SR. SÉRGIO ARAÚJO, atrás, no carona. Chegando ao destino, a Terra Indígena Passo Piraju, o SR. SÉRGIO ARAÚJO ficou no aguardo de socorro e nada soube informar a respeito de como o $\mathrm{Sr}$. Beline Chaves foi detido pelos demais indígenas de Passo Piraju. Afirmou não saber de quem era o carro que o vitimou nem foi-lhe possível reconhecer quem guiava o veículo.

É o que tinha a informar.

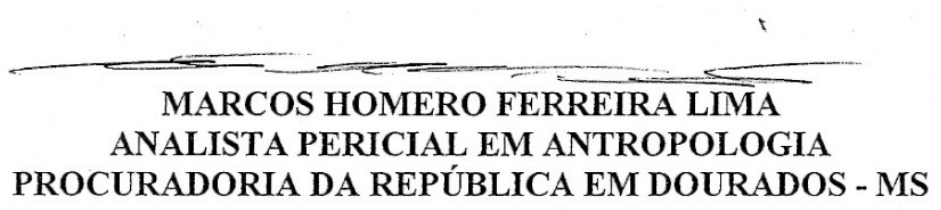

Recebido em: 29/05/2019* Aprovado em: 30/06/2019* Publicado em: 30/12/2019 